Review

\title{
Biological Activity of Recently Discovered Halogenated Marine Natural Products
}

\author{
Gordon W. Gribble \\ Department of Chemistry, Dartmouth College, Hanover, NH 03755, USA; \\ E-Mail: gordon.w.gribble@dartmouth.edu; Tel.: +1-603-646-3118; Fax: +1-603-646-3946 \\ Academic Editor: Orazio Taglialatela-Scafati
}

Received: 26 May 2015 / Accepted: 17 June 2015 / Published: 30 June 2015

\begin{abstract}
This review presents the biological activity — antibacterial, antifungal, anti-parasitic, antiviral, antitumor, antiinflammatory, antioxidant, and enzymatic activity — of halogenated marine natural products discovered in the past five years. Newly discovered examples that do not report biological activity are not included.
\end{abstract}

Keywords: organohalogen; antibacterial; antiparasitic; antiviral; antitumor; antiinflammatory; antioxidant; natural products; organochlorine; organobromine

\section{Introduction}

From fewer than 50 examples of halogenated natural products that were known in 1968 [1], the number today is more than 5000 and steadily increasing [2-6]. A majority of these compounds are found in marine organisms and several recent reviews are available of marine natural products in general [7-10], in algae [11-13], in sponges [14-16], in invertebrates [17-19], in gorgonians [20], in bryophytes [21], in fungi [22], in cyanobacteria [23], in marine bacteria [24], and those cyano-containing marine triterpenoids [25]. Given the enormous advance in ocean exploration, including retrieving samples at depths reaching $11,000 \mathrm{~m}$ [26], it is inevitable that novel marine natural products are awaiting discovery.

In the present review I have chosen to focus on halogenated marine natural products possessing demonstrated biological activity that were reported during the period 2011-2015. My organization is according to the type of observed activity, and many of these marine metabolites have multiple activities and therefore appear in more than one section. 


\section{Antibacterial Activity}

Natural products represent an important potential source of new antibacterial drugs [27], particularly those that prevent biofouling by barnacles, tubeworms, mussels, and other "smothering" marine organisms [28,29].

Many gorgonian soft coral metabolites are biofilm inhibitors. For example, the South China Sea gorgonian Dichotella gemmacea has yielded several antibacterial briarane diterpenoids 1-12, several of which contain chlorine, as summarized in Figure 1 [30,31].

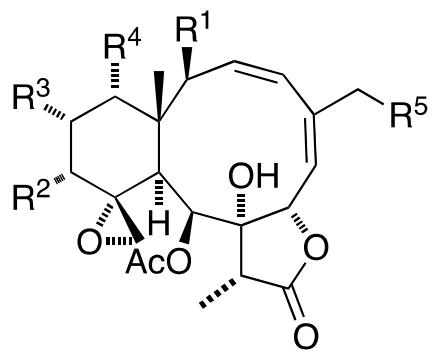

\begin{tabular}{llllll} 
Compound & \multicolumn{1}{c}{$\mathrm{R}^{1}$} & $\mathrm{R}^{2}$ & $\mathrm{R}^{3}$ & $\mathrm{R}^{4}$ & $\mathrm{R}^{5}$ \\
\hline gemmacolide N (1) & $\mathrm{OAc}$ & $\mathrm{OAc}$ & $\mathrm{H}$ & $\mathrm{OAc}$ & $\mathrm{OMe}$ \\
gemmacolide O (2) & $\mathrm{OCOCH}_{2} \mathrm{OH}$ & $\mathrm{OAc}$ & $\mathrm{OAc}$ & $\mathrm{OAc}$ & $\mathrm{Cl}$ \\
gemmacolide P (3) & $\mathrm{OAc}$ & $\mathrm{O} i$-Val & $\mathrm{OAc}$ & $\mathrm{OAc}$ & $\mathrm{OH}$ \\
gemmocolide Q (4) & $\mathrm{OCOCH}_{2} \mathrm{OH}$ & $\mathrm{O} i$-Val & $\mathrm{OAc}$ & $\mathrm{OAc}$ & $\mathrm{OH}$ \\
gemmacolide R (5) & $\mathrm{OCOCH}_{2} \mathrm{OH}$ & $\mathrm{OAc}$ & $\mathrm{OAc}$ & $\mathrm{O} i-\mathrm{Val}$ & $\mathrm{OH}$ \\
gemmacolide S (6) & $\mathrm{OCOCH}_{2} \mathrm{ONal}$ & $\mathrm{OAc}$ & $\mathrm{O} i-\mathrm{Val}$ & $\mathrm{OAc}$ & $\mathrm{O} i$-Val
\end{tabular}

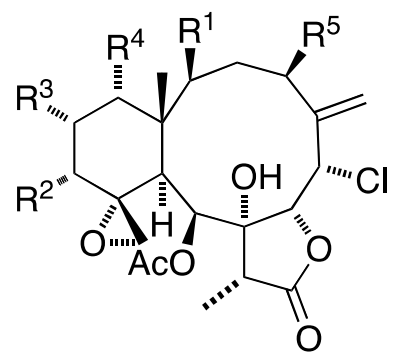

\begin{tabular}{llllll} 
Compound & $\mathrm{R}^{1}$ & $\mathrm{R}^{2}$ & $\mathrm{R}^{3}$ & $\mathrm{R}^{4}$ & $\mathrm{R}^{5}$ \\
\hline gemmacolide T (7) & OAc & Oi-Val & $\mathrm{H}$ & OAc & OAc \\
gemmacolide U (8) & OAc & OAc & $\mathrm{H}$ & Oi-Val & OAc \\
gemmacolide V (9) & OAc & OAc & $\mathrm{H}$ & OAc & OAc \\
gemmocolide W (10) & OAc & OAc & Oi-Val & OAc & Oi-Val
\end{tabular}

Figure 1. Cont. 


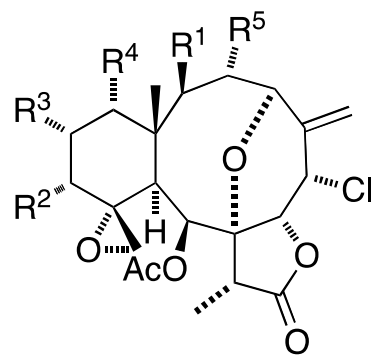

\begin{tabular}{llllll} 
Compound & $\mathrm{R}^{1}$ & $\mathrm{R}^{2}$ & $\mathrm{R}^{3}$ & $\mathrm{R}^{4}$ & $\mathrm{R}^{5}$ \\
\hline gemmacolide $\mathrm{X}(\mathbf{1 1})$ & OAc & OAc & $\mathrm{H}$ & OAc & OAc \\
gemmacolide $\mathrm{Y}(\mathbf{1 2})$ & OAc & O $i$-Val & $\mathrm{H}$ & OAc & OAc
\end{tabular}

Figure 1. Structures of gemmacolide briarane diterpenoids from Dichotella gemmacea [30,31].

Of these gemmacolides, $\mathrm{N}(\mathbf{1}), \mathrm{O}(\mathbf{2})$, and Q (4) show antibacterial activity against the Gram-negative bacterium $E$. coli in the agar diffusion assay, with the chlorinated gemmacolide $O$ being the most active [30]. Antitumor and antifungal activities are discussed in the appropriate sections to follow.

The prolific gorgonian Dichotella gemmacea is also the source of numerous new briarane diterpenoids, the dichotellides, many of which contain chlorine or iodine or both [32-34]. In particular, of the 16 novel briarane diterpenoids, dichotellides F-U, found in Dichotella gemmacea, H (13), I (14), K (15), L (16), M (17), N (18), O (19), P (20), and U (21) exhibit potent antifouling activities (Figure 2; Table 1) [34].

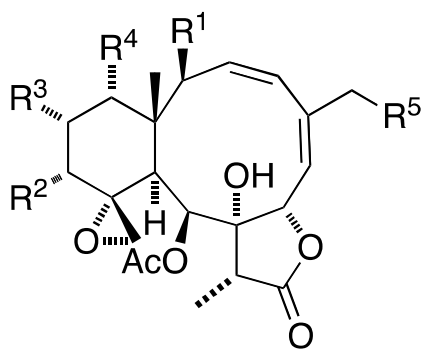

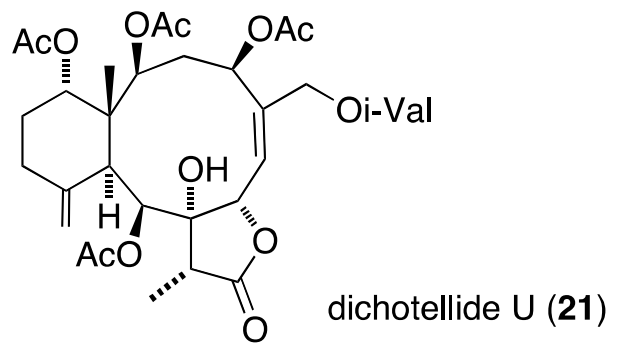

\begin{tabular}{llllll} 
Compound & \multicolumn{1}{c}{$\mathrm{R}^{1}$} & $\mathrm{R}^{2}$ & $\mathrm{R}^{3}$ & $\mathrm{R}^{4}$ & $\mathrm{R}^{5}$ \\
\hline dichotellide H (13) & $\mathrm{OCOCH}_{2} \mathrm{O} i$-Val & Oi-Val & OAc & OAc & $\mathrm{Cl}$ \\
dichotellide I (14) & $\mathrm{OCOCH}_{2} \mathrm{O} i$-Val & OAc & OAc & OAc & Oi-Val \\
dichotellide K (15) & OAc & OAc & Oi-Val & OAc & Oi-Val \\
dichotellide L (16) & OAc & OAc & OAc & Oi-Val & Oi-Val \\
dichotellide M (17) & OAc & Oi-Val & Oi-Val & OAc & OMe \\
dichotellide N (18) & OAc & OAc & $\mathrm{H}$ & Oi-Val & OMe \\
dichotellide O (19) & OAc & Oi-Val & $\mathrm{H}$ & OAc & OMe \\
dichotellide P (20) & OAc & OAc & $\mathrm{H}$ & Oi-Val & Oi-Val
\end{tabular}

Figure 2. Structures of selected dichotellide briarane diterpenoids from Dichotella gemmacea [34]. 
Table 1. Biofouling activity of dichotellides (13-21) against the larval settlement of the barnacle Balanus amphitrite [34].

\begin{tabular}{ccc}
\hline Compound & $\mathbf{E C}_{\mathbf{5 0}}(\boldsymbol{\mu g} / \mathbf{m L})^{\mathbf{a}}$ & $\mathbf{L C}_{\mathbf{5 0}} / \mathbf{E C}_{\mathbf{5 0}} \mathbf{b}^{\mathbf{b}}$ \\
\hline H (13) & 4.1 & $>24$ \\
I (14) & 1.82 & $>54.9$ \\
K (15) & 6.3 & $>16$ \\
L (16) & 7.6 & $>13$ \\
M (17) & 4.6 & $>11$ \\
N (18) & 1.2 & $>88$ \\
O (19) & 5.6 & $>18$ \\
P (20) & 0.79 & $>126.6$ \\
U (21) & 2.0 & $>48$ \\
\hline
\end{tabular}

${ }^{\mathrm{a}}$ Effective concentration for $50 \%$ inhibition; ${ }^{\mathrm{b}}$ Lethal concentration/effective concentration.

The South China Sea gorgonian Junceella fragilis has also yielded 12 new briarane diterpenoids, fragilisinins A-L (22-33) (Figure 3), several of which have potent antifouling activity, but are not superior to the previously known junceelloide A and junceellonoid D (Table 2) [35].

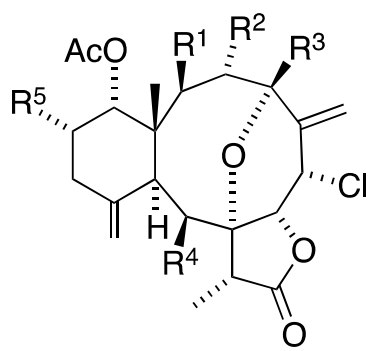

\begin{tabular}{llllll} 
Compound & $\mathrm{R}^{1}$ & $\mathrm{R}^{2}$ & $\mathrm{R}^{3}$ & $\mathrm{R}^{4}$ & $\mathrm{R}^{5}$ \\
\hline fragilisinin A (22) & $\mathrm{OAc}$ & $\mathrm{H}$ & $\mathrm{OH}$ & $\mathrm{OH}$ & $\mathrm{H}$ \\
fragilisinin D (23) & $\mathrm{OAc}$ & $\mathrm{OAc}$ & $\mathrm{H}$ & $\mathrm{OH}$ & $\mathrm{H}$ \\
fragilisinin I (24) & $\mathrm{OAc}$ & $\mathrm{I}$ & $\mathrm{H}$ & $\mathrm{OAc}$ & $\mathrm{H}$ \\
fragilisinin J (25) & $\mathrm{OAc}$ & $\mathrm{I}$ & $\mathrm{H}$ & $\mathrm{OAc}$ & $\mathrm{OAc}$ \\
junceellolide A (34) & $\mathrm{OAc}$ & $\mathrm{H}$ & $\mathrm{OH}$ & $\mathrm{OAc}$ & $\mathrm{H}$ \\
junceellonoid D (35) & $\mathrm{OH}$ & $\mathrm{OH}$ & $\mathrm{H}$ & $\mathrm{OAc}$ & $\mathrm{H}$
\end{tabular}

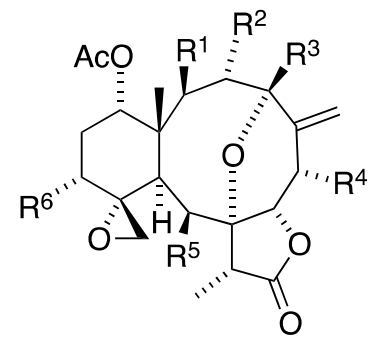

\begin{tabular}{lllllll} 
Compound & $\mathrm{R}^{1}$ & $\mathrm{R}^{2}$ & $\mathrm{R}^{3}$ & $\mathrm{R}^{4}$ & $\mathrm{R}^{5}$ & $\mathrm{R}^{6}$ \\
\hline fragilisinin $\mathrm{B} \mathrm{(26)}$ & $\mathrm{OAc}$ & $\mathrm{H}$ & $\mathrm{OH}$ & $\mathrm{Cl}$ & $\mathrm{OH}$ & $\mathrm{H}$ \\
fragilisinin C (27) & $\mathrm{OAc}$ & $\mathrm{OAc}$ & $\mathrm{H}$ & $\mathrm{Cl}$ & $\mathrm{OH}$ & $\mathrm{H}$ \\
fragilisinin K (28) & $\mathrm{OAc}$ & $\mathrm{I}$ & $\mathrm{H}$ & $\mathrm{OMe}$ & $\mathrm{OAc}$ & $\mathrm{H}$ \\
fragilisinin L (29) & $\mathrm{OCOEt}$ & $\mathrm{I}$ & $\mathrm{H}$ & $\mathrm{Cl}$ & $\mathrm{OAc}$ & $\mathrm{H}$
\end{tabular}

Figure 3. Cont. 


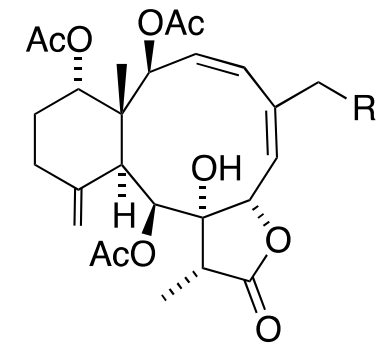

fragilisinin $E, R=O M e(30)$ fragilisinin $\mathrm{H}, \mathrm{R}=\mathrm{OH}(\mathbf{3 1})$

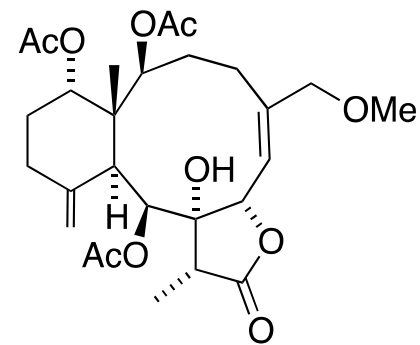

fragilisinin $F(32)$

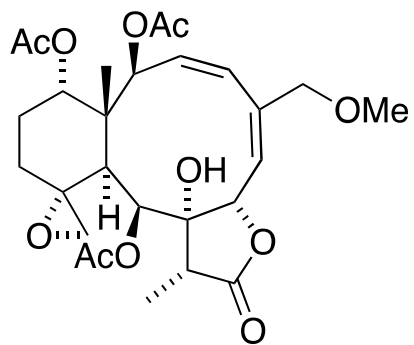

fragilisinin $G(33)$

Figure 3. Structures of fragilisinins A-L briarane diterpenoids from Junceella fragilis [35].

Table 2. Biofouling activity of fragilisinins against the larval settlement of the barnacle Balanus amphitrite [35].

\begin{tabular}{lcc}
\hline \multicolumn{1}{c}{ Compound } & $\mathbf{E C}_{\mathbf{5 0}}(\boldsymbol{\mu M})$ & $\mathbf{L C}_{\mathbf{5 0}} / \mathbf{E C}_{\mathbf{5 0}}$ \\
\hline fragilisinin E (30) & 14.0 & $>13$ \\
fragilisinin F (32) & 12.6 & $>14.5$ \\
fragilisinin J (25) & 11.9 & $>11.5$ \\
junceellolide A (34) $_{\text {junceellonoid D (35) }}$ & 5.6 & $>33.3$ \\
positive control $^{\text {a }}$ & 10.0 & $>20$ \\
\hline
\end{tabular}

a 5-octylfuran-2(5H)-one.

An examination of the Chinese soft coral Sinularia rigida has yielded 19 new cembrane diterpenoids, the sinulariols, of which $\mathrm{J}(\mathbf{3 6})$ and $\mathrm{P}(\mathbf{3 7})$ display antifouling activity against $B$. amphitrite $(5.65 \mu \mathrm{g} / \mathrm{mL})$ and B. neritina $(14.03 \mu \mathrm{g} / \mathrm{mL})$, respectively (Figure 4). The one chlorinecontaining example, sinulariol E (38) is less active [36].

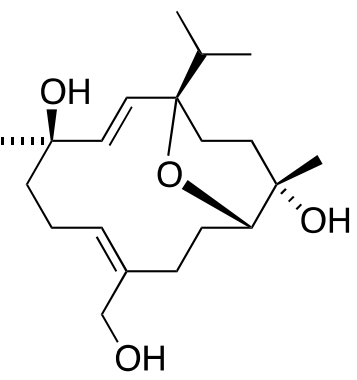

sinulariol J (36)

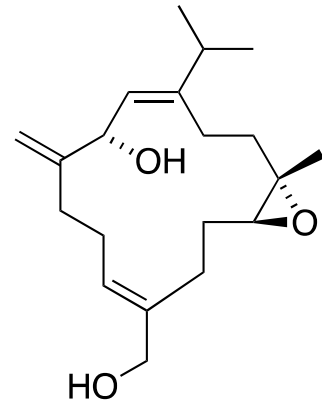

sinulariol $P(37)$

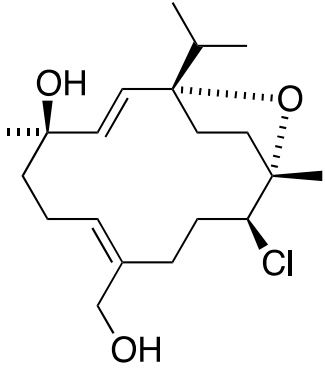

sinulariol $E(\mathbf{3 8})$

Figure 4. Structures of selected sinulariol cembrane diterpenoids from Sinularia rigida [36].

Potent antifouling activity is observed in some newly isolated resorcylic acid lactones found in the fungus Cochlionbolus lunatus derived from the gorgonian Dichotella gemmacea. Thus obtained were cochliomycins A-C (39-41) (Figure 5) [37,38]. Only cochliomycin A (39) shows potent activity against Balanus amphitrite $\left(\mathrm{EC}_{50} 1.2 \mu \mathrm{g} / \mathrm{mL} ; \mathrm{LC}_{50} / \mathrm{EC}_{50}>16.7\right)$, which was superior to the known analogues zeaenol, LL-Z1640-1, and LL-Z1640-2. Insufficient material of cochliomycins B and C was available for testing. 
<smiles>C/C=C/C[C@@H](O)[C@H]1OC(C)(C)O[C@@H]1/C=C\CC(C)OC(=O)c1c(O)cc(OC)cc1OC</smiles>

cochliomucin A (39)<smiles></smiles>

cochliomucin B (40)<smiles>C/C=C/CC(O)[C@H](O)C(O)/C=C\CC(C)OC(=O)c1c(O)cc(OC)cc1OC</smiles>

cochliomucin C (41)

Figure 5. Structures of cochliomycins A-C (39-41) from Cochliobolus lunatus [37,38].

Another soft-coral derived fungus, Pestalotiopsis sp. from the South China Sea Sarcophyton sp., contains the novel $( \pm$ )-pestalachloride $D(42)$ and the known analogue $( \pm)$-pestalachloride $C(43)$ (Figure 6) $[39,40]$. Both compounds are active against the bacteria E. coli, Vibrio anguillarum, and Vibrio parahaemolyticus with MIC values of 5.0, 10.0, and $20.0 \mu \mathrm{M}$, respectively [39].<smiles>COc1c(Cl)c(C)c(Cl)c2c1C1c3c(O)cc(O)c(C=O)c3CC1C(C)(C)O2</smiles>

pestalachloride $D(\mathbf{4 2})$<smiles>COc1c(Cl)c(C)c(Cl)c2c1[C@]1(OC1(C)C)c1c(O)c(O)cc(O)c1C[C@H]2C</smiles>

pestalachloride C (43)

Figure 6. Structures of ( \pm )-pestalachlorides D (42) and C (43) from Pestalotiopsis sp. [39,40].

The Antarctic soft coral Alcyonium roseum has yielded the two new illudalanes, alcyopterosins 44 and 45 (Figure 7) [41]. Although insufficient material was available for antibacterial testing, the authors believe that these metabolites may be feeding deterrents for the predatory sea star Odontaster validus and have antifouling activity, based on similar properties of related alcyopterosins. The soft-coral associated actinomycetes strain, Streptomyces sp. OUCMDZ-1703 has yielded the novel strepchloritides A (46) and B (47), which exhibit modest activity against E. coli, Pseudomonas aeruginosa, and S. aureus (Figure 7).<smiles>[R]c1cc2c(c(CCCl)c1C)C(OC(C)=O)C(C)(C)C2</smiles>

alcyopterosin $(\mathrm{R}=\mathrm{Me}) \mathbf{4 4}$ alcyopterosin $(\mathrm{R}=\mathrm{CHO}) 45$<smiles>[R]C(Cl)(Cl)C(=O)/C=C(\O)c1cc(O)cc(O)c1</smiles>

strepchloritide $A(R=H)(46)$ strepchloritide $B(R=C l)(47)$

Figure 7. Structures of alcyopterosins 44 and 45 from Alcyonium roseum [41], and strepchloritides A (46) and B (47) from Streptomyces sp. OUCMDZ-1703 [42]. 
The Mediterranean gorgonian Paramuricea clavata is reported to contain three new brominated metabolites, 2-bromo- $N$-methyltryptamine (48), 3-bromo- $N$-methyltyramine (49), and 6-bromo- $N$-methyltryptamine (50) (Figure 8) in addition to several known analogues [43]. Compound 50 was previously known from synthesis. Of the ten compounds tested, $\mathbf{4 8}$ shows the highest activity in preventing adhesion of three bacterial strains (Pseudoalteromonas sp. D41 and TC8, and Paracoccus sp. 4M6). However, insufficient material was available for toxicity screening.

The marine sponge Pseudoceratina sp. has yielded numerous brominated alkaloids with biological activity [2-4], including the four new pseudoceramines A-D (51-54) collected from this sponge in the Great Barrier Reef, Queensland, Australia (Figure 9) [44]. Pseudoceramine B (52) inhibits bacterial growth with $\mathrm{IC}_{50} 40 \mu \mathrm{M}$.<smiles>[R]c1ccc2c(CCNC)c(Br)[nH]c2c1</smiles>

$48\left(R^{1}=B r, R^{2}=H\right)$ $50\left(\mathrm{R}^{1}=\mathrm{H}, \mathrm{R}^{2}=\mathrm{Br}\right)$<smiles>CNCCc1ccc(O)c(Br)c1</smiles>

49

Figure 8. Brominated compounds 48-50 from Paramuricea clavata [43].<smiles>COc1c(Br)cc(C/C(=N\O)C(=O)NCCCN(C)CCCCN(C)CCCNC(=O)/C(Cc2cc(Br)cc(Br)c2)=N/O)cc1Br</smiles><smiles>CNC(Cc1cc(Br)c(OC)c(Br)c1)C(=O)NCCCN(C)CCCCN(C)CCCNC(=O)/C(Cc1cc(Br)c(OC)c(Br)c1)=N/O</smiles><smiles>CNCCCCN(C)CCCNC(=O)/C(Cc1cc(Br)c(OC)c(Br)c1)=N/O</smiles>

pseudoceramine C (53)<smiles>COc1c(Br)cc(C/C(=N/O)C(=O)NCCCNC(=O)OCc2ccccc2)cc1Br</smiles>

Figure 9. Structures of pseudoceramines A-D (51-54) from the sponge Pseudoceratina sp. [44].

Of the 12 bromotyrosines isolated from the southern Australian sponge Pseudoceratina sp., four were new metabolites: aplysamine-7 (55), (-)-purealin B (56), purealin C (57), and purealin D (58) (Figure 10) [45]. Purealin $C$ shows a broad spectrum of activity against two strains each of the 
Gram-positive $S$. aureus (IC50 2.6 and $6.2 \mu \mathrm{M}$ ) and B. subtilis (IC50 2.6 and $2.8 \mu \mathrm{M}$ ), while $(-)$-purealin B is only active against $B$. subtilis $\left(\mathrm{IC}_{50} 3.4\right.$ and $\left.3.8 \mu \mathrm{M}\right)$.

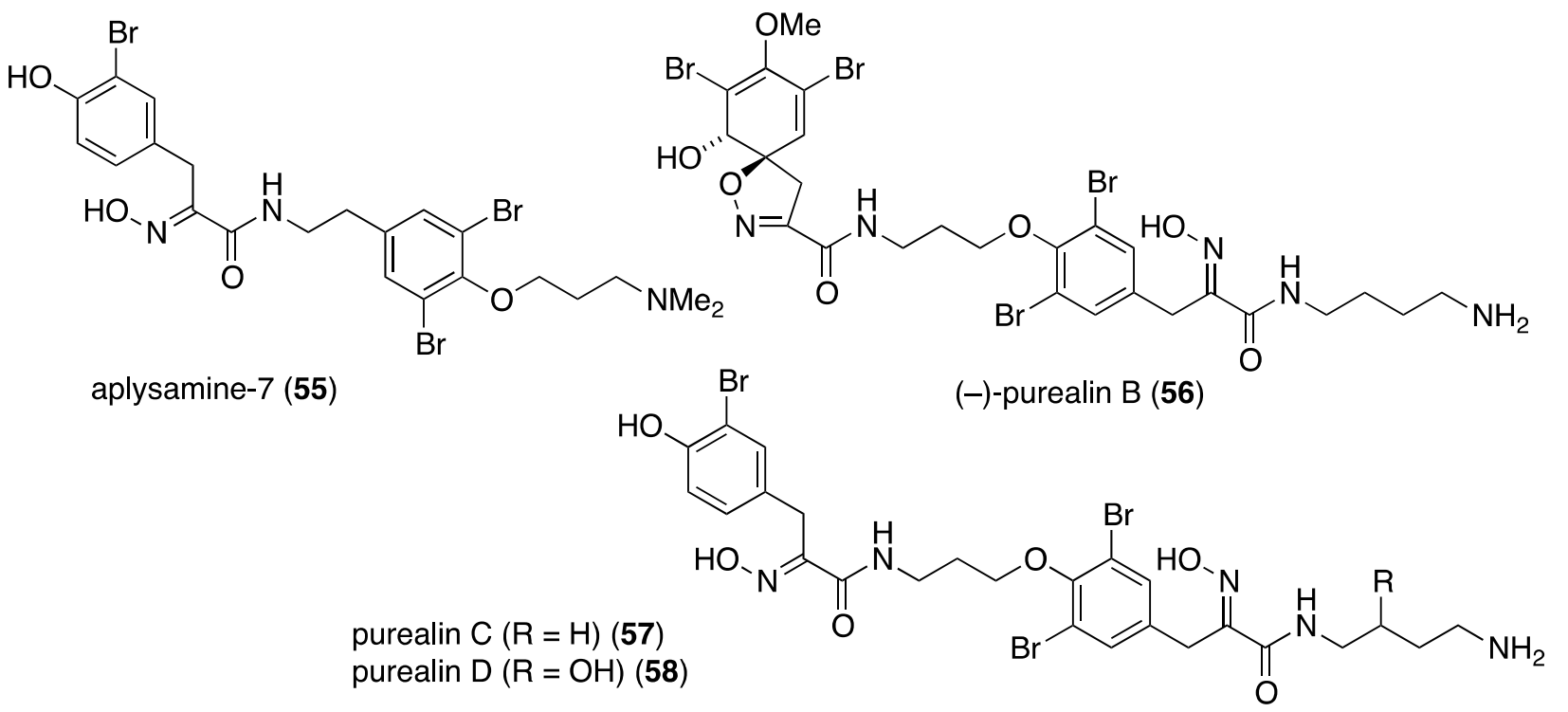

Figure 10. Structures of bromotyrosines 55-58 from the sponge Pseudoceratina sp. [45].

A collection of the sponge Iotrochota purpurea from Hainan Island, China, has yielded the ten new halogenated purpuroines A-J (59-68), five of which contain iodine (Figure 11) [46]. In addition to antifungal activity to be discussed in the next section, purpuroine I (67) shows selective inhibition of the human pathogen Streptococcus pneumonia (IC50 $18.06 \pm 0.76 \mu \mathrm{g} / \mathrm{mL}$; ampicillin, IC $\mathrm{I}_{50}$ $0.38 \pm 0.029 \mu \mathrm{g} / \mathrm{mL}$ ).<smiles></smiles>

purpuroine $A\left(R^{1}=R^{2}=R^{3}=B r\right)(59)$ purpuroine $B\left(R^{1}=R^{2}=B r, R^{3}=H\right)(60)$ purpuroine $C\left(R^{1}=R^{3}=C l, R^{2}=B r\right)(61)$ purpuroine $D\left(R^{1}=R^{2}=B r, R^{3}=I\right)(62)$ purpuroine $E\left(R^{1}=R^{2}=B r, R^{3}=C l\right)(63)$<smiles>[R]c1cc(CC(C(=O)[O-])C([N+](=O)[O-])[N+](=O)[O-])cc([R])c1[R7]</smiles>

purpuronine $F\left(R^{1}=R^{3}=I, R^{2}=M e\right)(64)$ purpuronine $G\left(R^{1}=R^{3}=I, R^{2}=H\right)(65)$ purpuronine $H\left(R^{1}=B r, R^{2}=M e, R^{3}=I\right)(66)$ purpuronine I $\left(\mathrm{R}^{1}=\mathrm{Br}, \mathrm{R}^{2}=\mathrm{H}, \mathrm{R}^{3}=\mathrm{I}\right)(\mathbf{6 7})$<smiles>CC(=O)C(Cc1c[nH]c2cc(Br)ccc12)C(C)C</smiles>

purpuroine $\mathrm{J}(68)$

Figure 11. Structures of purpuroines A-J (59-68) from the sponge Iotrochota purpurea [46].

The deep-sea Great Australian Bight sponge, Axinella sp., contains the three new brominated imidazoles, 14- $O$-sulfate massadine (69), 14- $O$-methyl massadine (70), and 3- $O$-methyl massadine chloride (71) (Figure 12) [47]. The latter chlorine-containing metabolite (71) exhibits antibacterial activity against the Gram-positive bacteria Staphylococcus aureus (ATCC 9144 and 25923; IC 503.7 and $4.2 \mu \mathrm{M}$, respectively) and B. subtilis (ATCC 6051 and 6633; IC50 2.6 and $2.2 \mu \mathrm{M}$, respectively), and the Gram-negative bacteria E. coli (ATCC 11775; IC50 $4.4 \mu \mathrm{M}$ ) and P. aeruginosa (ATCC 10145; $\left.\mathrm{IC}_{50} 4.9 \mu \mathrm{M}\right)$. The effect of the chlorine atom is noteworthy. 


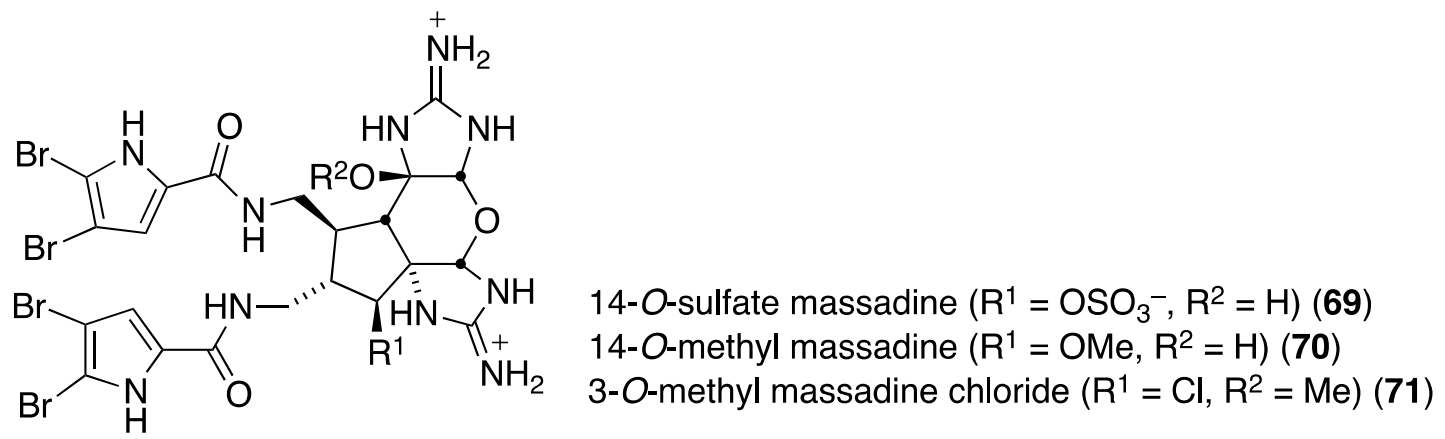

Figure 12. Structures of massadines 69-71 from the sponge Axinella sp. [47].

A deep-water Asteropus sponge from the Bahamas contains the novel indolo[3,2-a]carbazoles 72 and 73 (Figure 13); 72 shows some activity against methicillin-resistant $S$. aureus (MRSA; minimum inhibitory concentration (MIC) of $50 \mu \mathrm{g} / \mathrm{mL}$ [48].<smiles>[R]OC1=Cc2[nH]c3ccc4c(cc(Br)ccc4c2C2=CC(O)=C(O)C=[Se]12)[nH]3</smiles>

Figure 13. Structures of indolo[3,2-a]carbazoles 72 and 73 from the sponge Asteropus sp. [48].

Examination of the southern Australian sponge Ianthella sp. has revealed the presence of dictyodendrins F-J (74-78) (Figure 14) [49]. Antibacterial activity is limited to the Gram-positive B. subtilis (ATCC 6051 and 6633): 74 (IC 502.7 and $2.3 \mu \mathrm{M}$ ), 76 (IC 501.2 and $3.1 \mu \mathrm{M}$ ), and 77 (IC 502.5 and $2.8 \mu \mathrm{M}$ ).<smiles></smiles>

dictyodendrin $F(R=H, X=H)(74)$ dictyodendrin $\mathrm{G}(\mathrm{R}=\mathrm{Me}, \mathrm{X}=\mathrm{H})(\mathbf{7 5})$ dictyodendrin $\mathrm{H}(\mathrm{R}=\mathrm{H}, \mathrm{X}=\mathrm{Br})(\mathbf{7 6})$ dictyodendrin I $(\mathrm{R}=\mathrm{H}, \mathrm{X}=\mathrm{I})(77)$<smiles></smiles>

dictyodendrin $\mathrm{J}(\mathbf{7 8})$

Figure 14. Structures of dictyodendrins F-J (74-78) from the sponge Ianthella sp. [49].

A series of structurally novel indole alkaloids was isolated from the Okinawan sponge Suberites sp., including nakijinamines A (79), B (80), F (81), G (82), H (83), I (84), and 6-bromoconicamin (85) 
(Figure 15) [50]. An earlier study by this same research team identified the related nakijinamines $\mathrm{C}-\mathrm{E}$ (not shown) [51]. Of these alkaloids, only nakijinamine A (79) is active against $S$. aureus (MIC $16 \mu \mathrm{g} / \mathrm{mL}$ ), B. subtilis (MIC $16 \mu \mathrm{g} / \mathrm{mL}$ ), and Micrococcus luteus (MIC $2 \mu \mathrm{g} / \mathrm{mL}$ ). Nakijinamine I (84) is the first aaptamine-type alkaloid to have a 1,4-dioxane unit.<smiles></smiles>

nakijinamine $A(R=B r)(79)$ nakijinamine $B(R=H)(80)$<smiles>CN(C)C=Cc1c[nH]c2cc(Br)ccc12</smiles>

6-bromoconicamin (85)<smiles></smiles>

nakijinamine $F(R=$ iso- $\mathrm{Bu})(\mathbf{8 1})$ nakijinamine $\mathrm{G}(\mathrm{R}=\mathrm{sec}-\mathrm{Bu})(\mathbf{8 2})$ nakijinamine $\mathrm{H}\left(\mathrm{R}=\mathrm{CH}_{2} \mathrm{Ph}\right)(\mathbf{8 3})$<smiles></smiles>

nakijinamine I (84)

Figure 15. Structures of nakijinamines 79-84 and 6-bromoconicamin $(\mathbf{8 5})$ from the sponge Suberites sp. [50].

The Okinawan sponge Agelas sp. is a rich source of brominated pyrrole alkaloids and several recent studies have added to this collection. The agelasines O-U (86-92) from Agelas sp. (NSS-19) are novel diterpene alkaloids tethered to a 9-N-methyladenine unit (Figure 16) [52]. Of these alkaloids, only agelasines O-R (86-89) and T (91) show activity against $S$. aureus and B. subtilis (MIC 8.0-32.0 $\mu \mathrm{g} / \mathrm{mL}$ ), but not against $E$. coli $(\mathrm{MIC} \geq 32.0 \mu \mathrm{g} / \mathrm{mL})$. For both strains the activity decreases: Q $(\mathbf{8 8}) \sim \mathrm{R}(\mathbf{8 9})$ $>\mathrm{O}(\mathbf{8 6}) \sim \mathrm{T}(\mathbf{9 1})>\mathrm{P}(\mathbf{8 7})$.

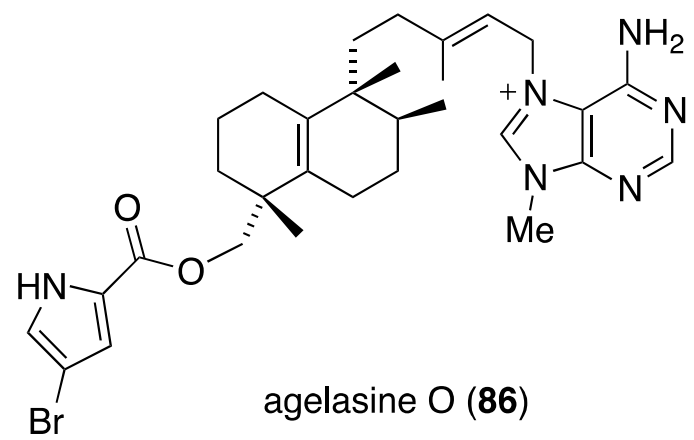<smiles>C[C@H]1CC[C@]2(C)C(COC(=O)c3cc(Br)c[nH]3)=CC(=O)C[C@H]2[C@@]12CC/C(=C/C[n+]1cn(C)c3ncnc(N)c31)C[C@H]2C</smiles>

Figure 16. Cont. 


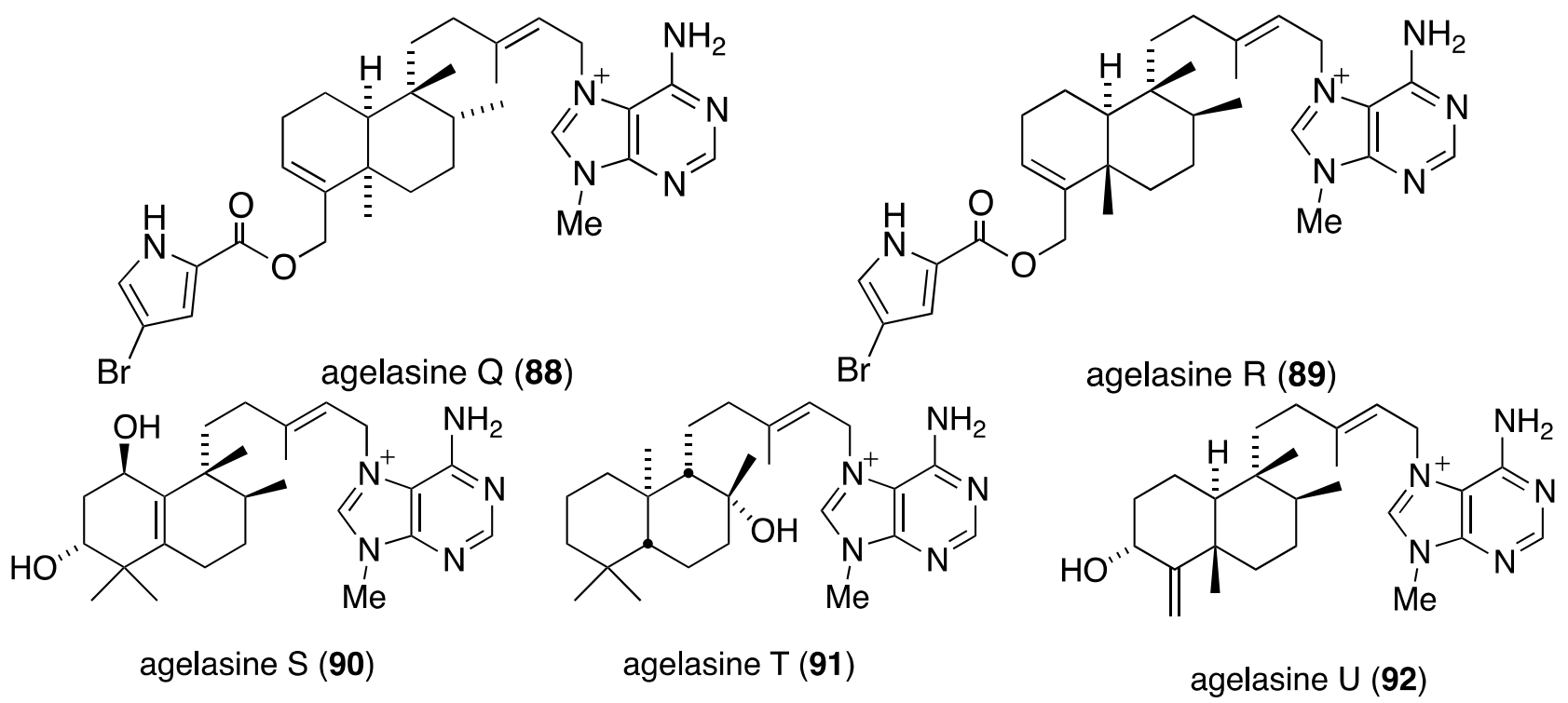

Figure 16. Structures of agelasines $\mathrm{O}-\mathrm{U}(\mathbf{8 6}-\mathbf{9 2})$ from the sponge Agelas sp. [52].

Another examination of the sponge Agelas sp. (SS-162) from the Kerama Islands, Okinawa, has led to the isolation of the new bromopyrrole alkaloids, 2-bromokeramadine (93), 2-bromo-9, 10-dihydrokeramadine (94), tauroacidins C (95) and D (96), and mukanadin G (97) (Figure 17) [53]. Of these bromopyrroles, only 2-bromokeramadine (93) shows (weak) activity against $E$. coli, although mukanadin G (97) has moderate antifungal activity (next section). The highly complex agelamadins A (98) and B (99) were also characterized in the Okinawan sponge Agelas sp. (SS-162) (Figure 18) [54]. Both bromopyrroles are active against B. subtilis (MIC, $16 \mu \mathrm{g} / \mathrm{mL}$ each) and Micrococcus luteus (MIC, 4.0 and $8.0 \mu \mathrm{g} / \mathrm{mL}$, respectively). The related agelamadins $\mathrm{C}-\mathrm{E}$ exhibit only antifungal activity as shown in the next section.

The South China Sea sponge Acanthella cavernosa contains eight new chlorinated diterpenoids, kalihinols M-T (100-107) (Figure 18). In addition, seven previously isolated analogues were isolated [55]. Kalihinols O (102), P (103), Q (104), R (105), S (106), and T (107) exhibit significant antifouling activity against Balanus amphitrite larvae: $\mathrm{EC}_{50}$ 1.43, 0.72, 1.48, 1.16, 0.53, and $0.74 \mu \mathrm{M}$, respectively.<smiles>C[n+]1c(/C=C/CNC(=O)c2cc(Br)c(Br)[nH]2)c[nH]c1N</smiles>

2-bromokeramadine (93)<smiles>COC(/C=C1\NC(=N)[NH+]=C1NCCS(=O)(=O)[O-])CNC(=O)c1cc(Br)c(Br)[nH]1</smiles>

tauroacidin C (95)<smiles>Cn1c(CCCNC(=O)c2cc(Br)c(Br)[nH]2)c[nH+]c1N</smiles>

2-bromo-9,10-dihydrokeramadine (94)<smiles>N=C1NC(=CC(=O)CNC(=O)c2cc(Br)c(Br)[nH]2)C(NCCS(=O)(=O)[O-])=[NH+]1</smiles>

tauroacidin D (96)

Figure 17. Cont. 
<smiles></smiles>

mukanadin $\mathrm{G}(\mathbf{9 7})$<smiles>[R][C@]1(c2cnc(N)[nH]2)[C@@H]2[NH+]=C(N)N[C@@H]2[C@H]2NC(=O)c3cc(Br)c(Br)n3[C@H]21</smiles>

agelamadin $\mathrm{A}(\mathrm{R}=\mathrm{OMe})(\mathbf{9 8})$ agelamadin $\mathrm{B}(\mathrm{R}=\mathrm{OH})(\mathbf{9 9})$

Figure 17. Structures of bromopyrroles 93-99 from the sponge Agelas sp. (SS-162) [53,54].<smiles>CC(C)(Cl)[C@@H]1CC[C@@H]([C@H]2CC[C@](C)(N(S)S)[C@H]3CC[C@](C)(NC(=O)O)[C@H](O)[C@H]23)O1</smiles>

kalihinol M (100)

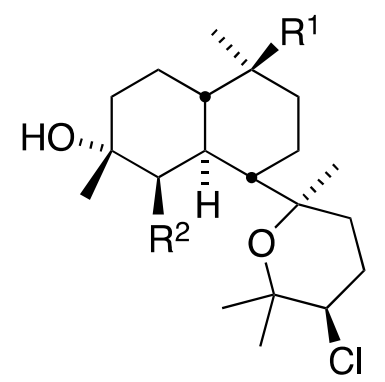

kalihinol $O\left(R^{1}=N C S, R^{2}=N C\right)(102)$ kalihinol $Q\left(R^{1}=N C, R^{2}=N C S\right)(104)$ kalihinol $R\left(R^{1}=R^{2}=N C S\right)(105)$<smiles>CC1(C)O[C@H](C2CC[C@](C)(N(S)S(=O)(=O)[O-])[C@H]3CC[C@](C)(NC(=O)O)[C@H](O)[C@H]23)C[C@@H]1Cl</smiles>

kalihinol N (101)

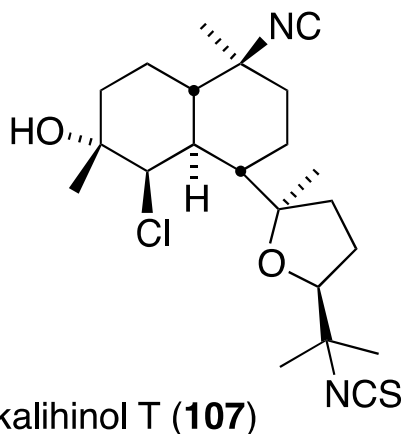

kalihinol T (107)

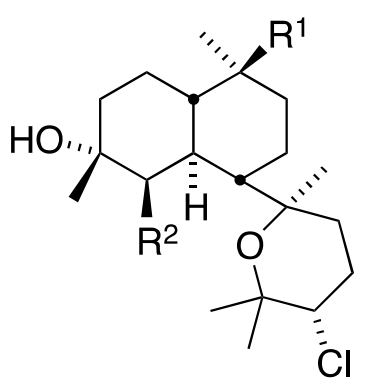

kalihinol $P\left(R^{1}=N C, R^{2}=N C S\right)(103)$

kalihinol $S\left(R^{1}=\right.$ NCS, $R^{2}=$ NHCHO) (106)

Figure 18. Structures of kalihinols M-T (100-107) from the sponge Acanthella caverenosa [55].

While no new marinopyrroles were reported in the time frame for this review, it is important to cite an excellent survey of these antibacterial marine halogenated pyrroles [56] and an equally excellent report on their activity against methicillin-resistant $S$. aureus, including synthetic marinopyrrole analogues [57].

Like gorgonians and marine sponges, algae employ a chemical arsenal to prevent bacterial smothering (biofouling), and several examples of halogenated antibacterial compounds have been isolated from algae. 
<smiles>[R]C1C(=O)C(Br)=C(Br)[C@]1(O)C(Br)Br</smiles>

mahorone $(\mathrm{R}=\mathrm{H})(\mathbf{1 0 8})$

5-bromomahorone $(\mathrm{R}=\mathrm{Br})(\mathbf{1 0 9})$<smiles>C=C1[C@H](C)CC=C(C)[C@@]12CC[C@H](Br)C(C)(Cl)C2</smiles>

laurokamin $A$ (112)<smiles>C=C(C)C(=O)/C(Cl)=C\[C@@](C)(Cl)C(Br)CCl</smiles>

plocamenone (110)<smiles>C=C(C)C(=O)/C(Cl)=C/[C@@](C)(Cl)[C@H](Br)CCl</smiles>

isoplocamenone (111)

Figure 19. Structures of red algae metabolites 108-114 [58-60].

The prodigious organohalogen-producing red alga Asparagopsis taxiformis "limu kohu," which is the favorate edible seaweed of native Hawaiians, and the source of more than 100 organohalogens [2,3], contains the unusual mahorone (108) and 5-bromomahorone (109) (Figure 19) [58]. Both compounds are highly toxic to the marine bacterium Vibrio fisheri ( $\mathrm{EC}_{50} 0.16 \mu \mathrm{M}$ for both), and both are most active against the Gram-negative bacterium Acinebacter baumanni and lesser activity towards E. coli and $S$. aureus. The red alga Plocamiun angustum metabolite plocamenone (110) inhibits the growth of B. subtilis comparable to that of chloramphenicol (inhibition zone of $10 \mathrm{~mm} v s .12 \mathrm{~mm}$, respectively). Species of Laurencia red algae continue to reveal novel halogenated natural products. A Chinese collection of Laurencia okamurae yielded the three new laurokamins A-C (112-114) (Figure 19) [60], but only laurokamins B (113) and C (114) show (weak) activity against E. coli (6 mm inhibition diameter).

Three omaezallenes (115-117) were isolated and characterized from a collection of Laurencia sp. from Omaezaki, Japan (Figure 20) [61]. Of the three metabolites, omaezallene (115) was the most active in an antifouling assay against the larvae of the barnacle Amphibalanus amphitrite (EC50 $0.22 \mu \mathrm{g} / \mathrm{mL}$ ), but only weakly toxic to the larvae ( $\mathrm{LC}_{50} 4.8 \mu \mathrm{g} / \mathrm{mL}$ ). The other metabolites have: 116, $\mathrm{EC}_{50} 0.30 \mu \mathrm{g} / \mathrm{mL}$, and 117, EC $501.5 \mu \mathrm{g} / \mathrm{mL}$.<smiles>CC/C(Br)=C\C=C\[C@@H](O)[C@H](Br)[C@H]1OC(/C=C(/C)Br)C[C@H]1O</smiles>

omaezallene (115)<smiles>CC/C(Br)=C\C=C\[C@@H](O)[C@H](Br)C1OC(C=C2C(C)=C=C2Br)C[C@H]1O</smiles>

116 (unnamed)<smiles>CC/C(Br)=C\CC[C@@H](O)[C@@H](Br)C1OC(C=C2C(C)=C(Br)[C@@H]2C)C[C@H]1O</smiles>

117 (unnamed)

Figure 20. Structures of omaezallenes 115-117 from the red alga Laurencia sp. [61].

A collection of Formosan Laurencia brongniarii afforded the new polybrominated indole, 4,5,6-tribromo-2-methylsulfinylindole (118) in addition to 11 known brominated indoles (Figure 21) [62]. Although 118 is inactive, of the known indoles, 119-121 show significant antibacterial activity against 
Enterobacter aerogenes (ATCC 13048), Salmonella enteritidis (ATCC 13076), and Serratia marcescens (ATCC 25419). Several bromoditerpenes were characterized from the red alga, Sphaerococcus coronopifolius, living in the Berlenga Nature Reserve, Peniche, Portugal. These include the new sphaerodactylomelol (122) and the previous known sphaeranes 123-126 (Figure 21) [63]. Although no activity against E. coli (ATCC 25922) and Pseudomonas aeruginosa (ATCC 27853) is observed for 122-126, sphaerodactylomelol (122), 123, and 125 are active against $S$. aureus $\left(\mathrm{IC}_{50}\right.$ 96.30, 22.42, and $6.35 \mu \mathrm{M}$, respectively).<smiles>CS(=O)c1cc2c(Br)c(Br)c(Br)cc2[nH]1</smiles>

118

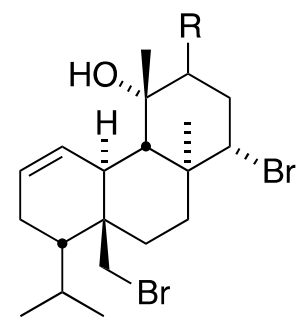

bromosphaerol $(\mathrm{R}=\mathrm{H})(\mathbf{1 2 3})$ 12S-hydroxybromosphaerol $(\mathrm{R}=-\mathrm{OH})(\mathbf{1 2 4})$ $12 R$-hydroxybromosphaerol $(\mathrm{R}=\cdots \cdot \mathrm{OH})(\mathbf{1 2 5})$<smiles>[R]c1[nH]c2cc(Br)c([R])c(Br)c2c1C</smiles>

$119\left(R^{1}=B r, R^{2}=H\right)$ $120\left(R^{1}=\mathrm{SMe}, \mathrm{R}^{2}=\mathrm{H}\right)$ $121\left(R^{1}=S M e, R^{2}=B r\right)$

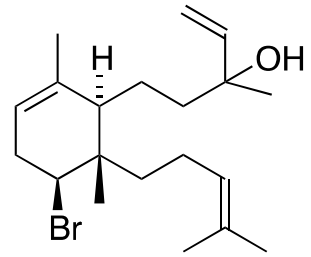

sphaerodactylomelol (122)

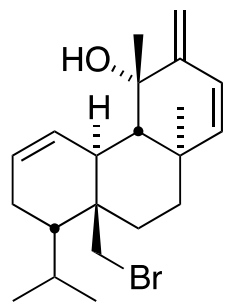

sphaerococcenol (126)

Figure 21. Structures of bromoindoles 118-121 and bromosphaerols 122-126 [62,63].

The Fijian red alga Callophycus sp. has yielded five new bromophycoic acids A-E (127-131) (Figure 22) [64]. These new examples of diterpene-benzoate marine natural products possess a range of biological activities, including antibacterial. For example, all five compounds are active against methicillin-resistant $S$. aureus (MIC $1.6-6.3 \mu \mathrm{g} / \mathrm{mL}$ ) with bromophycoic acid A (127) being comparable to vancomycin $(1.6 v s .2 \mu \mathrm{g} / \mathrm{mL})$. Likewise, bromophycoic acids $\mathrm{A}$ and $\mathrm{E}$ are active against vancomycin-resistant Enterococcus facium (MIC 6.3 and $1.6 \mu \mathrm{g} / \mathrm{mL}$, respectively).

The ascidian Synoicum sp. collected from Korean waters was found to contain eudistomins $\mathrm{Y}_{2}-\mathrm{Y}_{7}$ (132-137) (Figure 23) [65]. These known $\beta$-carbolines display a range of activity against both Gram-positive and Gram-negative bacteria (Table 3). This study also included the synthesis of several hydroxyl analogues via sodium borohydride reduction of the carbonyl group, but no improvement in antibacterial activity is observed. Although 132-137 were previously described, antibacterial activity was not reported [66].

Another examination of this ascidian from Korea has revealed the presence of nine new brominated furanones, cadiolides 138-142 and synoilides 143-146 (Figure 24) [67]. Cadiolides $H$ and synoilides $\mathrm{A}$ and $\mathrm{B}$ are interconverting $Z$ and $E$ isomers. Simultaneously with this study, another group isolated cadiolide E (138) along with the related cadiolides C (147), D (148), and F (149) from the ascidian Pseudodistoma antinboja (Figure 24) [68]. Like the eudistomins (Table 3), the cadiolides display significant antibacterial activity against both Gram-positive and Gram-negative bacteria (Table 4). The 
synoilides (143-146) show much weaker or no activity against these bacteria. Cadiolide F (149) and rubrolides $\mathrm{P}$ (150) and Q (151) also exist as interconverting $Z$ and $E$ isomers.
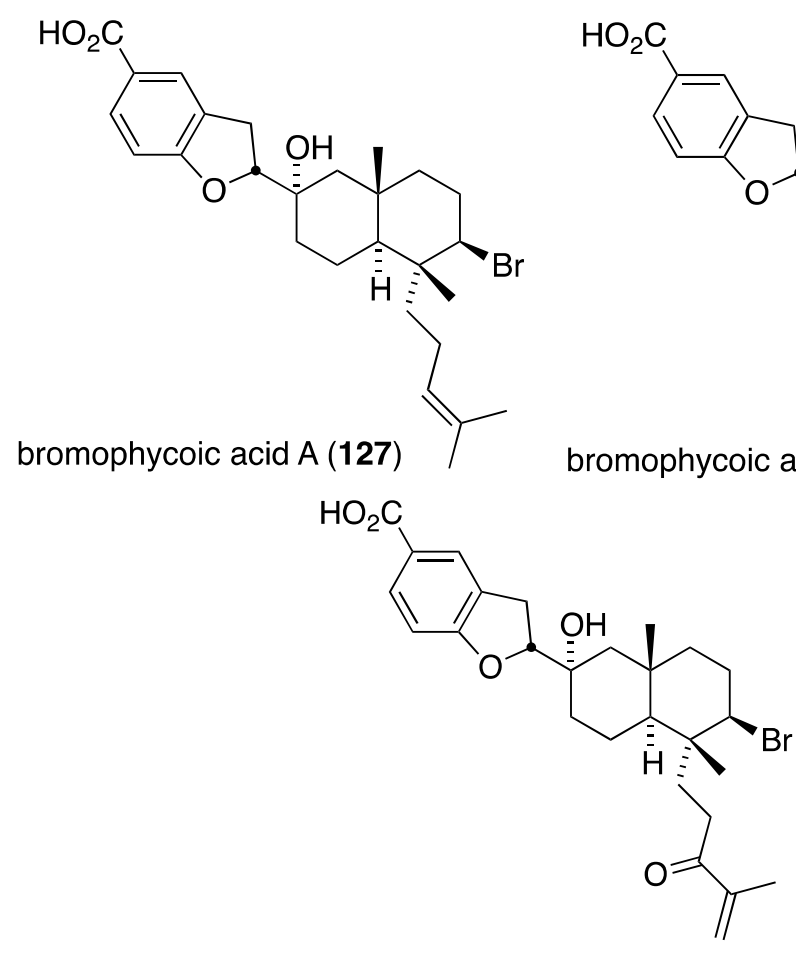

bromophycoic acid D (130)
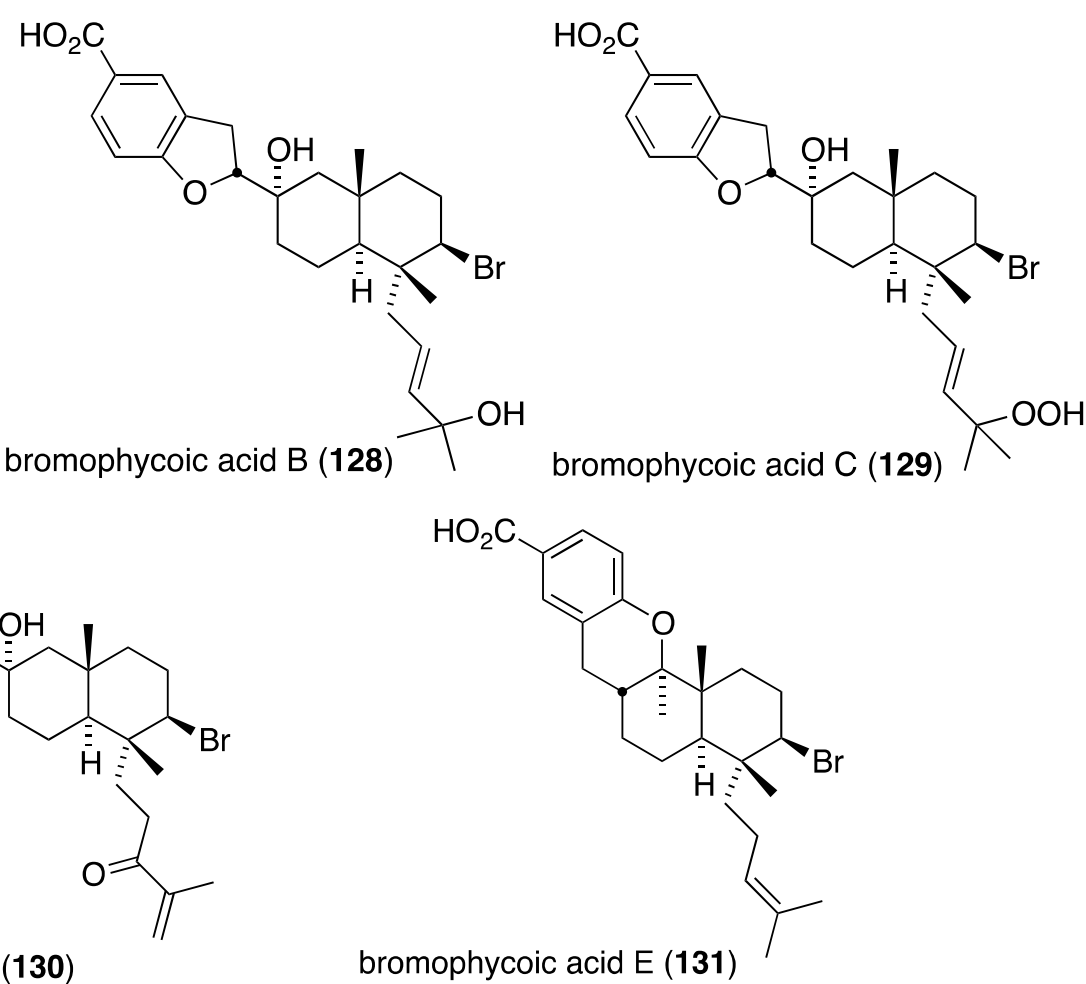

Figure 22. Structures of bromophycoic acids A-E (127-131) from the red alga Callophycus sp. [64].<smiles>[R]c1cc2[nH]c3c(C(=O)c4cc([R7])c(O)c([R8])c4)nccc3c2cc1[R]</smiles>

eudistomin $Y_{2}\left(R^{1}=B r, R^{2}=R^{3}=R^{4}=H\right)(132)$

eudistomin $Y_{3}\left(R^{3}=B r, R^{1}=R^{2}=R^{4}=H\right)(133)$

eudistomin $Y_{4}\left(R^{1}=R^{3}=B r, R^{2}=R^{4}=H\right)(134)$

eudistomin $Y_{5}\left(R^{3}=R^{4}=B r, R^{1}=R^{2}=H\right)(135)$

eudistomin $Y_{6}\left(R^{1}=R^{3}=R^{4}=B r, R^{3}=H\right)(136)$

eudistomin $Y_{7}\left(R^{2}=R^{3}=R^{4}=B r, R^{1}=H\right)(137)$

Figure 23. Structures of eudistomins $\mathrm{Y}_{2}-\mathrm{Y}_{7}(\mathbf{1 3 2}-\mathbf{1 3 7})$ from the ascidian Synoicum sp. [65].

Table 3. Antibacterial activity of eudistomins $\mathrm{Y}_{2}-\mathrm{Y}_{7}(\mathbf{1 3 2}-\mathbf{1 3 7})(\mathrm{MIC} \mu \mathrm{g} / \mathrm{mL})$ [65].

\begin{tabular}{lcccccc}
\hline \multicolumn{1}{c}{ Bacterium } & $\mathbf{Y}_{\mathbf{2}} \mathbf{( 1 3 2 )}$ & $\mathbf{Y}_{\mathbf{3}}(\mathbf{1 3 3})$ & $\mathbf{Y}_{\mathbf{4}} \mathbf{( 1 3 4 )}$ & $\mathbf{Y}_{\mathbf{5}} \mathbf{( 1 3 5 )}$ & $\mathbf{Y}_{\mathbf{6}}(\mathbf{1 3 6})$ & $\mathbf{Y}_{\mathbf{7}}(\mathbf{1 3 7 )}$ \\
\hline Staphylococcus aureus (ATCC 6538p) & 50 & 12.5 & 3.125 & 6.25 & 1.56 & 3.125 \\
Bacillus subtilis (ATCC 6633) & 25 & 12.5 & 0.78 & 3.125 & 1.56 & 0.78 \\
Micrococcus luteus (IFO 12708) & 25 & 12.5 & 1.56 & 3.125 & 1.56 & 1.56 \\
Salmonella typhimurium (ATCC 14028) & 50 & 6.25 & 0.39 & 0.78 & 0.39 & 0.78 \\
Proteus vulgaris (ATCC 3851) & 25 & 6.25 & 0.39 & 1.56 & 0.78 & 0.78 \\
Escherichia coli (ATCC 35270) & $>100$ & $>100$ & 50 & 100 & 50 & 50 \\
\hline
\end{tabular}

Similar to the cadiolides are the rubrolides and, in addition to rubrolides P (150) and Q (151), four new examples were found in a South African Synoicum globosum ascidian, 3"-bromorubrolide F (152), 3'-bromorubrolide E (153), 3'-bromorubrolide F (154), and 3',3"-dibromorubrolide E (155) 
(Figure 25) [69]. The previously known non-brominated rubrolides E (156) and F (157) were also isolated from this animal, and all six rubrolides display varying degrees of antibacterial activity (Table 5). It is noted that 3'-bromorubrolide F (154) is identical to rubrolide Q (151).<smiles>O=C1O/C(=C\c2cc(Br)c(O)c(Br)c2)C(c2ccc(O)c(Br)c2)=C1C(=O)c1cc(Br)c(O)c(Br)c1</smiles>

cadiolide $\mathrm{E}(\mathbf{1 3 8})$<smiles>[R20]c1ccc(C=C2OC(=O)C(C(O)c3cc(Br)c(OC)c(Br)c3)=C2c2cc([R7])c(O)c(Br)c2)cc1[R]</smiles><smiles>COC(=O)C1=C(c2cc(Br)c(O)c(Br)c2)C(=O)OC1=C(c1cc(Br)c(O)c(Br)c1)c1cc(Br)c(O)c(Br)c1</smiles>

cadiolide I (142)

cadiolide $\mathrm{G}\left(\mathrm{R}^{1}=\mathrm{R}^{3}=\mathrm{H}, \mathrm{R}^{2}=\mathrm{Br}, 4 Z\right)(\mathbf{1 3 9})$

cadiolide $H(Z)\left(R^{1}=B r, R^{2}=H, R^{3}=M e, 4 Z\right)(140)$

cadiolide $\mathrm{H}(E)\left(\mathrm{R}^{1}=\mathrm{Br}, \mathrm{R}^{2}=\mathrm{H}, \mathrm{R}^{3}=\mathrm{Me}, 4 E\right)(\mathbf{1 4 1})$<smiles>[R]OC(=O)C(C(=O)OC)=C(C(=O)c1cc(Br)c(O)c(Br)c1)c1cc(Br)c(O)c(Br)c1</smiles>

synoilide $A(Z)(R=B r, 2 Z)(143)$ synoilide $A(E)(R=B r, 2 E)(144)$ synoilide $B(Z)(R=H, 2 Z)(145)$ synoilide $B(E)(R=H, 2 E)(146)$<smiles>[R7]Oc1c([R])cc(C(=C2C=C(C(=O)c3cc(Br)c(O)c(Br)c3)C(=O)O2)c2cc([R7])c(O)c(Br)c2)cc1Br</smiles>

cadiolide $C\left(R^{1}=R^{2}=R^{3}=H\right)(147)$

cadiolide $D\left(R^{1}=B r, R^{2}=R^{3}=H\right)(148)$

cadiolide $F\left(R^{1}=R^{3}=H, R^{2}=M e\right)(149)$<smiles>[R7]c1cc([R7])cc(/C=C2\OC(=O)C=C2c2cc([R7])c(O)c(Br)c2)c1</smiles>

rubrolide $P\left(R^{1}=B r, R^{2}=R^{4}=H, R^{3}=M e\right)(150)$

rubrolide $Q\left(R^{1}=R^{2}=R^{4}=H, R^{3}=M e\right)(151)$

Figure 24. Structures of the cadiolides, synoilides, and rubrolides (138-151) from the ascidians Synoicum and Pseudodistoma antinboja [67,68]. 
Table 4. Antibacterial activity of cadiolides E, G, H, and I (138-142, 147-149) and rubrolides $\mathrm{P}$ and $\mathrm{Q}(\mathbf{1 5 0}, \mathbf{1 5 1})(\mathrm{MIC} \mu \mathrm{g} / \mathrm{mL})[67,68]$.

\begin{tabular}{lccccccccc}
\hline \multicolumn{1}{c}{ Bacterium } & $\mathbf{1 3 8}$ & $\mathbf{1 3 9}$ & $\mathbf{1 4 0 / 1 4 1}$ & $\mathbf{1 4 2}$ & $\mathbf{1 4 7}$ & $\mathbf{1 4 8}$ & $\mathbf{1 4 9}$ & $\mathbf{1 5 0}$ & $\mathbf{1 5 1}$ \\
\hline Staphylococcus aureus & 3.1 & 3.1 & 6.3 & 0.8 & 0.4 & 6.3 & 12.5 & 50 & 50 \\
Bacillus subtilis & 1.6 & 12.5 & 1.6 & 0.8 & 3.1 & 6.3 & 12.5 & 50 & 50 \\
Kocuria rhizophilia & 0.8 & 3.1 & 3.1 & 0.8 & - & - & - & - & - \\
Salmonella enterica & 1.6 & 0.8 & 3.1 & 1.6 & - & - & - & - & - \\
Proteus hauseri & 3.1 & 3.1 & 3.1 & 6.3 & - & - & - & - & - \\
Escherichia coli & $>100$ & $>100$ & $>100$ & $>100$ & - & - & - & - & - \\
Staphylococcus & - & - & & & 0.4 & 0.8 & 6.3 & 50 & 25 \\
epidermidis & - & - & & & & & & & \\
Kocuria rhizophila & - & - & & & 0.2 & 1.6 & 3.1 & 6.3 & 3.1 \\
\hline
\end{tabular}<smiles>[R]Oc1ccc(/C=C2\OC(=O)C=C2c2ccc(O)c([R])c2)cc1[R]</smiles>

$$
\begin{aligned}
& \text { 3"-bromorubrolide } F\left(R^{1}=H, R^{2}=B r, R^{3}=M e\right)(152) \\
& \text { 3'-bromorubrolide } E\left(R^{1}=B r, R^{2}=R^{3}=H\right)(153) \\
& \text { 3'-bromorubrolide } F\left(R^{1}=B r, R^{2}=H, R^{3}=M e\right)(154) \\
& \text { 3',3"-dibromorubrolide } E\left(R^{1}=R^{2}=B r, R^{3}=H\right)(155) \\
& \text { rubrolide } E\left(R^{1}=R^{2}=R^{3}=H\right)(156) \\
& \text { rubrolide } F\left(R^{1}=R^{2}=H, R^{3}=M e\right)(157)
\end{aligned}
$$

Figure 25. Structures of rubrolides 152-157 from the ascidian Synoicum globosum [69].

Table 5. Antibacterial activity of rubrolides 152-157 from the ascidian Synoicum globosum ( $\left.\mathrm{IC}_{50} \mu \mathrm{M}\right)$ [69].

\begin{tabular}{lcccccc}
\hline \multicolumn{1}{c}{ Bacterium } & $\mathbf{1 5 2}$ & $\mathbf{1 5 3}$ & $\mathbf{1 5 4}$ & $\mathbf{1 5 5}$ & $\mathbf{1 5 6}$ & $\mathbf{1 5 7}$ \\
\hline MRSA $^{\mathrm{a}}$ (ATCC BAA-1720) & 256 & 82 & 360 & 89 & 105 & 1006 \\
Staphylococcus epidermidis (ATCC 35984) $_{\text {Enterococcus faecalis (ATCC 700802) }}^{\mathrm{b}}$ & 98 & 38 & 42 & 28 & 21 & 79 \\
Escherichia coli (0157:H7) $^{\mathrm{b}}$ & 43 & 16 & 2 & 2 & 89 & 47 \\
\hline
\end{tabular}

a Methicillin-resistant Staphylococcus aureus; ${ }^{\mathrm{b}}$ Gentamycin- and vancomycin-resistant; percent growth at $100 \mu \mathrm{g} / \mathrm{mL}$.

The ascidian Synoicum pulmonaria from the Norwegian coast contains synoxazolidinones A (158) and C (159), and pulmonarins A (160) and B (161) (Figure 26) [70]. The two synoxazolidinones display broad activity against fouling marine species and $\mathbf{1 5 9}$ is comparable to the most active commercial antifouling product, Sea-Nine-211. In contrast, the pulmonarins prevent bacterial growth but have lower activity against microalgae and no activity towards barnacles (Table 6). In addition, several analogues were synthesized, but are generally less active than their natural counterparts. 
<smiles>COc1c(Br)cc(/C=C2\OC([C@H](Cl)CCNC(=N)N)NC2=O)cc1Br</smiles>

synoxazolidinone $A$ (158)<smiles>COc1c(Br)cc(C(=O)OCC[N+](C)(C)C)cc1Br</smiles>

pulmonarin A (160)<smiles>COc1c(Br)cc(/C=C2\OC3C(Cl)C[C@@H](NC(=N)N)N3C2=O)cc1Br</smiles>

synoxazolidinone C (159)<smiles>COc1c(Br)cc(CC(=O)NCCCCC[N+](C)(C)C)cc1Br</smiles>

pulmonarin B (161)

Figure 26. Structures of synoxazolidinones A (158) and C (159), and pulmonarians A (160) and B (161) from the ascidian Synoicum pulmonaria [70].

Table 6. Adhesion growth inhibition of synoxazolidiones $A$ (158) and $C$ (159), and pulmonarin A (160) from the ascidian Synoicum pulmonaria [70] ${ }^{\mathrm{a}}$.

\begin{tabular}{|c|c|c|c|c|c|c|c|c|}
\hline & \multicolumn{2}{|c|}{156} & \multicolumn{2}{|c|}{159} & \multicolumn{2}{|c|}{160} & \multicolumn{2}{|c|}{161} \\
\hline & Ad $^{b}$ & $\mathbf{G r}^{\mathrm{c}}$ & Ad & Gr & Ad & Gr & Ad & Gr \\
\hline \multicolumn{9}{|c|}{ Marine Bacteria } \\
\hline Halomonas aquamarina & 20 & - & - & 2 & 3 & - & - & - \\
\hline Polaribacter irgensii & - & 20 & 20 & 2 & - & 0.2 & - & - \\
\hline Pseudoalteromonas elyakovii & - & 0.02 & - & 20 & - & 0.2 & - & - \\
\hline Roseobacter litoralis & - & 0.02 & 2 & 0.2 & 0.03 & - & 20 & - \\
\hline Shewanella putrefaciens & - & 0.2 & - & 20 & - & - & - & - \\
\hline Vibrio aestuarians & - & 0.02 & 2 & 0.2 & 0.03 & - & 20 & - \\
\hline Vibrio carchariae & - & 2 & 20 & 2 & 3 & - & 20 & - \\
\hline Vibrio harveyi & - & - & 2 & 0.02 & - & - & - & - \\
\hline Vibrio natriegens & - & 0.02 & 20 & 2 & 0.03 & - & 20 & - \\
\hline Vibrio proteolylicus & - & 0.02 & 2 & 0.02 & - & - & - & - \\
\hline \multicolumn{9}{|c|}{ Microalgae } \\
\hline Cylindrotheca closterium & 20 & 20 & 2 & 0.2 & - & - & - & - \\
\hline Exanthemachrysis gayraliae & 20 & 20 & 2 & 0.2 & - & - & - & - \\
\hline Halamphora coffeaeformis & 20 & 20 & 2 & 2 & 30 & - & - & - \\
\hline Pleurochrysis roscoffensis & 20 & 20 & 2 & 2 & - & - & - & - \\
\hline Porphyridium purpureum & - & 20 & 0.2 & 0.02 & - & 0.2 & - & - \\
\hline
\end{tabular}

Balanus improvisus $\left(\mathrm{IC}_{50}\right)$

\section{Crustacean Settlement}

${ }^{\mathrm{a}}$ Inactive at $\geq 10 \mu \mathrm{g} / \mathrm{mL} ;{ }^{\mathrm{b}}$ Adhesion inhibition (MIC, $\mu \mathrm{M}$ ); ${ }^{\mathrm{c}}$ Growth inhibition (MIC, $\mu \mathrm{M}$ ).

Several novel antibacterial organohalogen marine fungal metabolites have been discovered in recent years. The fungus Bartalinia robillardoides (strain LF550), which was isolated from the Mediterranean sponge Tethya aurantium, produces three novel chloroazaphilones, helicusin E (162), isochromophilone X (163), and isochromophilone XI (164) (Figure 27) [71]. Only isochromophilone 
XI (164) shows antibacterial activity against B. subtilis ( $\left.\mathrm{IC}_{50} 55.6 \mu \mathrm{M}\right)$ and Staphylococcus lentus (IC50 $78.4 \mu \mathrm{M}$ ), which is slightly less active than the previously known deacetylsclerotiorin, also isolated from this fungus.<smiles>CCC(C)C(O)C(C)(O)/C=C/C1=CC2=C(Cl)C(=O)C(C)(OC(=O)/C=C(\C)CC(=O)O)C(=O)C2=CO1</smiles>

helicusin E (162)<smiles>CCC(C)/C=C(C)/C=C/C1=CC2=C(Cl)C(=O)[C@](C)(OC(=O)/C=C(\C)CC(=O)O)C(=O)C2=CN1CCO</smiles>

isochromophilone $X(\mathbf{1 6 3})$<smiles>CCC(C)/C=C(C)/C=C/C1=CC2=C(Cl)C(=O)C(C)(OC(=O)/C=C(\C)CC(=O)O)C(=O)C2(O)CO1</smiles>

isochromophilone $\mathrm{XI}(164)$

Figure 27. Structures of fungal metabolites 162-164 from the fungus Bartalinia robillardoides strain LF550 [71].

The deep-sea derived Spiromastix sp. fungus (collected at 2869 meters) has furnished 15 new spiromastixones A-O (165-179) (Figure 28) [72]. These novel chlorodepsidones display impressive antibacterial activity against the Gram-positive bacteria S. aureus (ATCC 29213), Bacillus thuringensis (SCS10 BT01), and B. subtilis (SCS10 BT01), but not against the Gram-negative E. coli (ATCC 25922). For example, spiromastixone J (175) has $0.125,0.25$, and $0.125 \mu \mathrm{g} / \mathrm{mL}$, respectively, against the three Gram-positive bacteria. Moreover, 175 is strongly inhibitory towards MRSA, methicillin-resistant Staphylococcus epidermidis (MRSE), and vancomycin-resistant Enterococcus faecalis and E. faecium (VSE). Spiromastixones F-I (171-174) are also potent inhibitors of MRSA and MRSE, and are superior to levofloxacin. This activity increases with an increasing number of chlorines.<smiles>[R8]c1c([R3])c2c(c([10BH])c1CCC)Oc1c([R7])c(O)c([R])c(CCC)c1C(=O)O2</smiles><smiles>[R]c1c([R])c([R])c2c(c1[R])OC(=O)c1c(CCC)c([R])c(O)c([R])c1O2</smiles>

spiromastixone $A\left(R^{1}=R^{2}=R^{3}=R^{5}=H, R^{4}=O H\right)(165)$ spiromastixone $B\left(R^{1}=R^{3}=R^{5}=H, R^{2}=C l, R^{4}=O H\right)(166)$ spiromastixone $C\left(R^{1}=\mathrm{Cl}, \mathrm{R}^{2}=\mathrm{R}^{3}=\mathrm{R}^{5}=\mathrm{H}, \mathrm{R}^{4}=\mathrm{OH}\right)(\mathbf{1 6 7})$ spiromastixone $D\left(R^{1}=R^{5}=C l, R^{2}=R^{3}=H, R^{4}=O H\right)(168)$ spiromastixone $E\left(R^{1}=R^{2}=C l, R^{3}=R^{5}=H, R^{4}=O H\right)(169)$ spiromastixone $F\left(R^{1}=R^{2}=R^{5}=C l, R^{3}=H, R^{4}=O H\right)(170)$ spiromastixone $G\left(R^{1}=R^{2}=R^{5}=\mathrm{Cl}, R^{3}=H, R^{4}=O M e\right)(171)$ spiromastixone $H\left(R^{1}=R^{2}=R^{3}=C l, R^{4}=O H, R^{5}=H\right)(172)$ spiromastixone I $\left(R^{1}=R^{2}=R^{3}=R^{5}=C l, R^{4}=O H\right)(173)$ spiromastixone $\mathrm{J}\left(\mathrm{R}^{1}=\mathrm{R}^{2}=\mathrm{R}^{3}=\mathrm{R}^{5}=\mathrm{Cl}, \mathrm{R}^{4}=\mathrm{OMe}\right)(\mathbf{1 7 4})$

spiromastixone $K\left(R^{1}=R^{2}=R^{5}=C l, R^{3}=H, R^{4}=O M e\right)(175)$ spiromastixone $L\left(R^{1}=R^{2}=R^{3}=R^{5}=C l, R^{4}=O M e\right)(176)$ spiromastixone $M\left(R^{1}=R^{2}=C l, R^{3}=R^{5}=H, R^{4}=O H\right)(177)$ spiromastixone $N\left(R^{1}=R^{2}=R^{5}=C l, R^{3}=H, R^{4}=O H\right)(178)$ spiromastixone $O\left(R^{1}=R^{2}=R^{3}=R^{5}=C l, R^{4}=O H\right)(179)$

Figure 28. Structures of spiromastixones A-O (165-179) from the fungus Spiromastix sp. [72]. 
Marine bacteria also produce antibacterial compounds, including those that contain halogen. Merochlorins A-D (180-183) are novel meroterpenoids isolated from the marine bacterium Streptomyces sp. strain CNH-189 from a California coastal sediment (Figure 29) [73,74]. Both merochlorins A (180) and B (181) are active against MRSA $(2-4 \mu \mathrm{g} / \mathrm{mL})$, and $\mathbf{1 8 0}$ is active in vitro against Clostridium difficile.<smiles>CC(C)=CCC[C@]12CC(=C(C)C)C[C@@H]1[C@@](C)(CCC=C(C)C)C(=O)C2(Cl)Cl</smiles>

merochlorin A (180)<smiles>CC(C)=CCC[C@]1(C)OC2=C(Cl)C(=O)c3c(O)cc(O)cc3[C@]21CC(C)=C(C)C</smiles>

merochlorin B (181)<smiles>CC(C)=CCC(=O)C1(O)CC(C)=CCC(C)=C1C(=O)c1cc(OC(C)(C)C(C)Cl)cc(O)c1C</smiles>

merochlorin C (182)<smiles>CC(C)=CCC/C(C)=C\C/C(C)=C(/C)C[C@]1(O)C(=O)c2cc(O)cc(O)c2C(=O)C1(C)Cl</smiles>

merochlorin D (183)

Figure 29. Structures of merochlorins A-D (180-183) from Streptomyces sp. CNH-189 [73,74].

Another California marine sediment contains Streptomyces strains CNQ-329 and CNH-070, which produce the six novel napyradiomycins A-F (184-189) (Figure 30) along with three previously known napyradiomycins B2-B4 (e.g., B3 = 190) [75]. Of these metabolites, napyradiomycins A (184) and B3 (190) are the most active against MRSA (MIC 16 and $2 \mu \mathrm{g} / \mathrm{mL}$, respectively).<smiles>[R]C1C=C2C(=O)c3c(O)c(C/C(=C\CC/C(C)=C/CCO)CO)cc(O)c3C(=O)C2OC1(C)C</smiles>

napyradiomycin $A(R=\alpha-C l)(\mathbf{1 8 4})$ napyradiomycin $B(R=\beta-\mathrm{OH})(\mathbf{1 8 5})$<smiles>C=C1CCC(P)C(C)(C)C1CC12OC(C)(C)[C@@H](Cl)C=C1C(=O)c1c(O)cc(O)cc1C2=O</smiles>

napyradiomycin $\mathrm{E}(\mathrm{R}=\mathrm{Br})(\mathbf{1 8 8})$ napyradiomycin $\mathrm{B} 2(\mathrm{R}=\mathrm{Cl})$

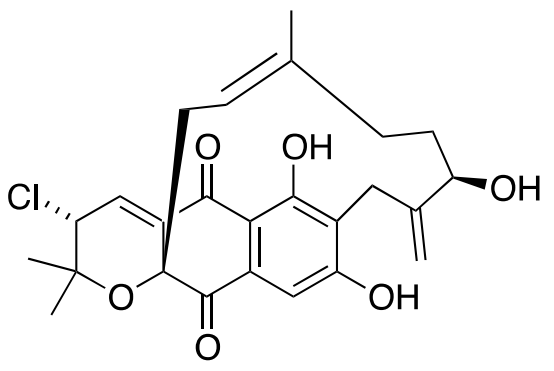

napyradiomycin C (186)

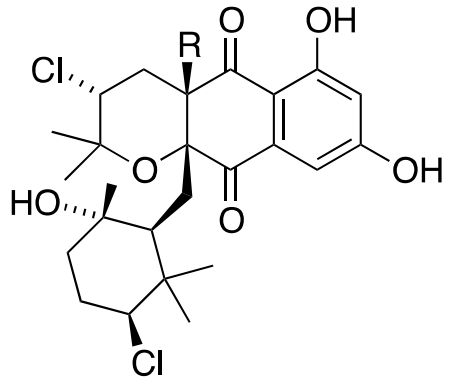

napyradiomycin $F(R=H)(\mathbf{1 8 9})$ napyradiomycin $\mathrm{B} 3(\mathrm{R}=\mathrm{Cl})(\mathbf{1 9 0})$

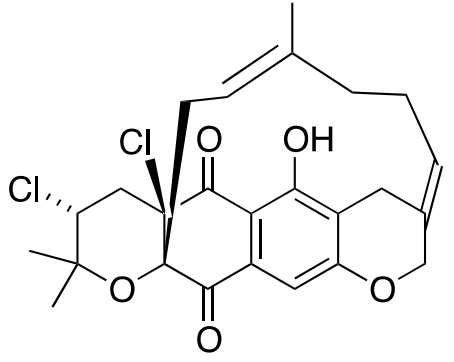

napyradiomycin $D$ (187)

Figure 30. Structures of napyradiomycins A-F (184-189) from Streptomyces CNQ-329 and $\mathrm{CNH}-070$ [75]. 
A Chinese collection of the marine-derived Streptomyces sp. SCS10 10428 has afforded the three new napyradiomycins 191-193, in addition to several known analogues, including napyradiomycins B1 and B3 (190) (Figure 31) [76]. Metabolites 191 and 192 are strongly active against $S$. aureus ATCC 29213 (MIC 4 and $0.5 \mu \mathrm{g} / \mathrm{mL}$, respectively), and all three napyradiomycins are active against B. thuringiensis SCS10 BT01 and B. subtilis SCS10 BS01 (MIC 1-6 $\mu \mathrm{g} / \mathrm{mL}$ ).
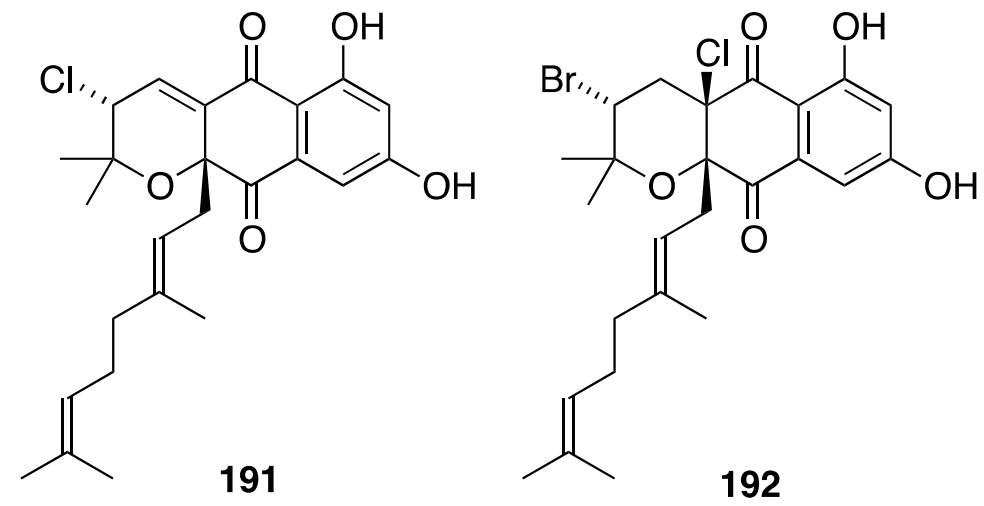<smiles>CC1(C)OC2=C(C[C@H]1Cl)C(=O)c1c(O)cc(O)cc1C2=O</smiles>

Figure 31. Structures of napyradiomycins 191-193 [76].

From a coastal sediment in Germany there was isolated the novel salimabromide (194), produced by the marine myxobacterium Enhygromxya salina (Figure 32) [77]. This structurally unusual compound has modest activity only against Arthrobacter cristallopoedes.<smiles></smiles>

\section{salimabromide (194)}

Figure 32. Structure of salimabromide (194) from the marine myxobacterium Enhygromxya salina [77].

Cyanobacteria (blue-green algae) are prodigious producers of biologically active organohalogen natural products, and a collection of Leptolyngbya crossbyana found overgrowing on Hawaiian coral yielded the new honaucins A-C (195-197) (Figure 33) [78]. All three compounds inhibit quorum sensing against Vibrio harveyi BB120 ( $\mathrm{IC}_{50}$ 5.6, 17.6, and $14.6 \mu \mathrm{M}$, respectively), and to a lesser extent towards E. coli JB525. Interestingly, the synthetic brominated and iodinated analogues of honaucin A (195) are more active in quorum sensing inhibition than the natural honaucin A itself. A Guamanian cyanobacterium which is very similar to Lyngbya produces the novel biologically active lipids pitinoic acids A-C (198-200), which inhibit quorum sensing in the Gram-negative bacterium Pseudomonas aeruginosa (Figure 33) [79]. 
<smiles>O=C(/C=C/CCl)O[C@@H]1COC(=O)C1</smiles>

honaucin A (195)<smiles>CC(COC(=O)/C=C/CCl)CC(C)C(=O)O</smiles>

honaucin $B(R=E t)(196)$

honaucin $C(R=M e)(197)$<smiles>C=C(CCCCC)CCCC(=O)O</smiles>

pitinoic acid $A(198)$<smiles>C=C(CCCCC)CCCC(=O)OC(CC=CCl)C(=O)O</smiles><smiles>O=C(O)[C@H](O)C/C=C/Cl</smiles>

pitinoic acid C (200)

Figure 33. Structures of honaucins A-C (195-197) from the cyanobacterium Leptolyngbya crossbyana [78], and pitinoic acids A-C (198-200) from a cyanobacterium [79].

\section{Antifungal Activity}

In addition to their often potent antibacterial activity (vide supra), many marine sponges contain halogenated metabolites with powerful antifungal properties. The new tetramic acid glycoside, aurantoside K (201), was isolated from a Fijian sponge belonging to the genus Melophlus (Figure 34) [80]. Auranotoside $\mathrm{K}$ is a demethylated analogue of the previously known aurantoside I. Although devoid of antibacterial, antimalarial, and cytotoxicity in the assays examined, 201 displays broad antifungal activity towards Candida albicans (wild type ATCC 32354 and amphotericin-resistant ATCC 90873; MIC 31.25 and $1.95 \mu \mathrm{g} / \mathrm{mL}$, respectively), Cryptococcus neoformans, Aspergillus niger, Penicillium sp., Rhizopus sporangia, and Sordaria sp. The Indonesian sponge Theonella swinhoei has yielded the new aurantoside $\mathrm{J}$ (202), which is an epimer of the previously known auranotoside G (Figure 34) [81]. The new 202 differs from aurantoside $\mathrm{G}$ at the anomeric center $\mathrm{C}-1^{\prime}$ of the xylose sugar unit. Antifungal activity of $\mathbf{2 0 2}$ is negligible compared to that of aurantosides G and I.

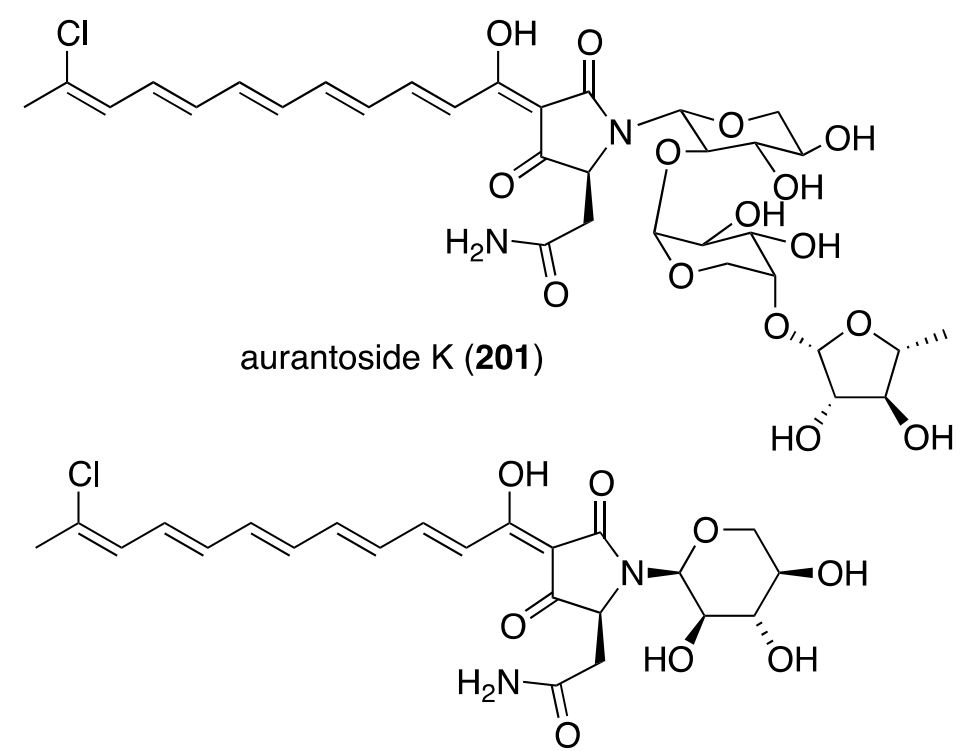

aurantoside $\mathrm{J}$ (202)

Figure 34. Structure of aurantoside K (201) from the sponge Melophlus sp. [80] and aurantoside J (202) from the sponge Theonella swinhoei [81]. 
A Red Sea specimen of Theonella swinhoei contains the antifungal glycopeptide theonellamide G (203) (Figure 35), which is very similar to the known theonellamide A, lacking only a methyl group on the $p$-bromophenylalanine and a hydroxyl group in the $\alpha$-aminoadipic acid group [82]. Theonellamide $\mathrm{G}$ shows potent antifungal activity against both wild and amphotericin B-resistant strains of Candida albicans; IC50 4.49 and $2.0 \mu \mathrm{M}$, respectively. The positive control amphotericin B had $1.48 \mu \mathrm{M}$ against the wild type Candida albicans.

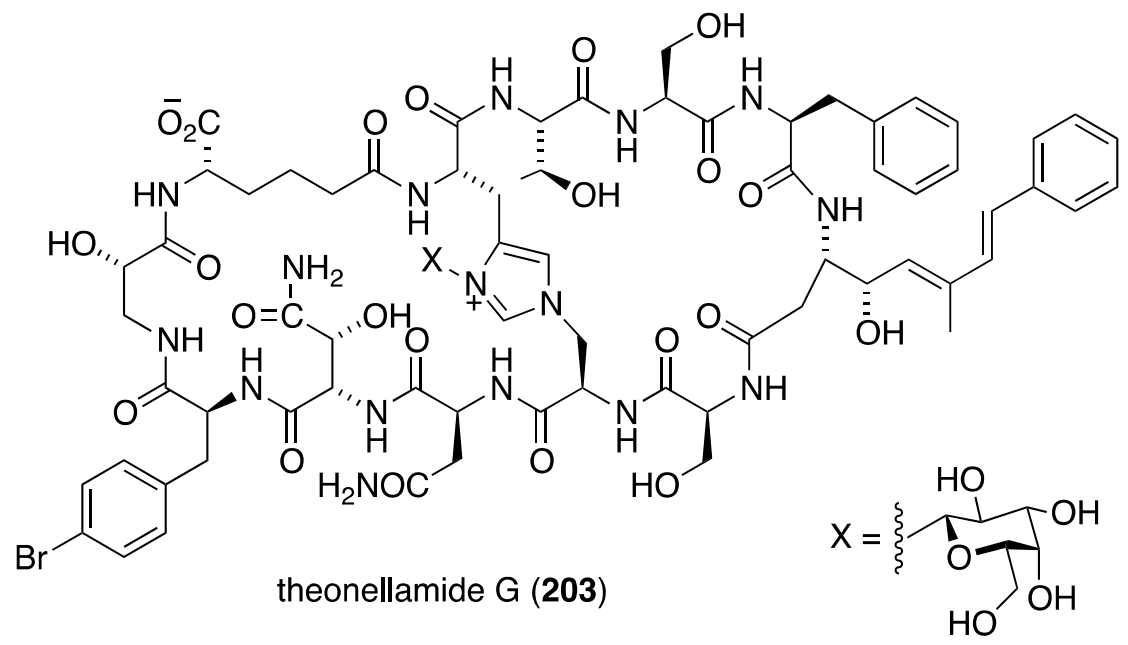

Figure 35. Structure of theonellamide G (203) from the sponge Theonella swinhoei [82].

The New Zealand sponge Hamigera tarangaensis has yielded a suite of new hamigerans (204-211) (Figure 36), in addition to several known related hamigerans [83]. Hamigeran $\mathrm{G}$ (205) also exists as an enol tautomer, and hamigeran F (204) undergoes what appears to be an acid-catalyzed retro-aldol transformation (observed in a $\mathrm{CDCl}_{3}$ solution of 204). Hamigeran $\mathrm{G}$ selectively inhibits the growth of two strains of the yeast Saccharomyces cerevisiae.

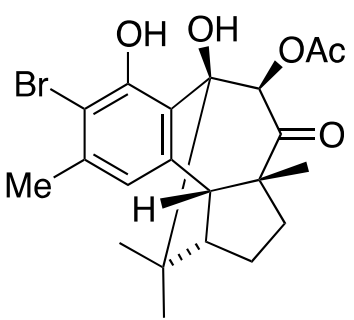

hamigeran F (204)<smiles>COC(=O)[C@]1(O)C(=O)[C@]2(C)CC[C@@H](C(C)C)[C@]2(C(C)=O)c2cc(C)c(Br)c(O)c21</smiles>

hamigeran $J(208)$<smiles>Cc1cc2c(c(O)c1Br)C(=O)C(=O)C[C@]1(C)CC[C@H](C(C)C)[C@H]21</smiles>

hamigeran $\mathrm{G}$ (205)<smiles>Cc1c(Br)c(O)c2c(c1Br)[C@H]1[C@H](C(C)C)CC[C@]1(C)[C@@H](O)C(=O)C2Br</smiles>

4-bromohamigeran K (209)<smiles>CC(=O)O[C@H]1C(=O)[C@](C)(O)c2c(O)cc(C)cc2[C@]2(C)CC[C@H](C(C)C)[C@]12C</smiles>

hamigeran $\mathrm{H}(\mathbf{2 0 6})$<smiles>COc1cc2c(c(O)c1Br)C(=O)C(O)[C@H](O)[C@@]1(C)CC[C@H](C(C)C)[C@]21C</smiles>

hamigeran I (207)<smiles>Cc1cc([C@]2(C(=O)O)[C@H](C(C)C)CC[C@@]2(C)CC(=O)O)c(C)c(O)c1Br</smiles>

hamigeran $L(R=H)(210)$

hamigeran $\mathrm{L}$ 11-O-methyl ester $(\mathrm{R}=\mathrm{Me})(\mathbf{2 1 1})$

Figure 36. Structures of hamigerans 204-211 from the sponge Hamigera tarangaensis [83]. 
The indolo[3,2-a]carbazole $\mathbf{7 2}$ from the deep-water sponge Asteropus sp. is antifungal towards Candida albicans (MIC $25 \mu \mathrm{g} / \mathrm{mL}$ ), but 73 is not [48]. Similarly, purpuroine D (61) is active against C. albicans (IC50 $19.03 \pm 0.12 \mu \mathrm{g} / \mathrm{mL}$ ), and purpuroines A (59), C (60), and D (61) inhibit the human disease-causing Aspergillus fumigates (IC50 $28.58 \pm 0.52,26.07 \pm 0.55,25.56 \pm 0.44 \mu \mathrm{g} / \mathrm{mL}$, respectively) [46]. The previously cited nakijinamine A (79) shows antifungal activity towards C. albicans ( $\mathrm{IC}_{50} 0.25 \mu \mathrm{g} / \mathrm{mL}$ ), Cryptococcus neoformans ( $\mathrm{IC}_{50} 0.5 \mu \mathrm{g} / \mathrm{mL}$ ), and Trichophyton mentagrophytes $\left(\mathrm{IC}_{50} 0.25 \mu \mathrm{g} / \mathrm{mL}\right)$. Less activity against $C$. albicans is seen with nakijinamines $\mathrm{B}(\mathbf{8 0})$ and $\mathrm{F}$ (81) (IC50 $8 \mu \mathrm{g} / \mathrm{mL}$ each) [50]. The Agelas sponge metabolites, agelasines O (86), P (87), Q (88), $\mathrm{R}(\mathbf{8 9})$, and $\mathrm{T}$ (91) show varying degrees of activity against the fungi $C$. albicans, Aspergillus niger, Trichophyton mentagrophytes, and Cryptococcus neoformans, with the greatest activity towards the latter fungus by $\mathrm{Q}(\mathbf{8 8})$ and $\mathrm{R}(\mathbf{8 9})\left(\mathrm{IC}_{50} 8.0 \mu \mathrm{g} / \mathrm{mL}\right.$ each) [52]. Similarly, these four fungi species are inhibited by the Agelas bromopyrroles 93-97, especially mukanadin G (97) against C. albicans and Cryptococcus neoformans ( $\mathrm{IC}_{50} 16$ and $8.0 \mu \mathrm{g} / \mathrm{mL}$, respectively) [53]. In addition to the Agelas sp. sponge metabolites agelamadins A (98) and B (99) [54], the new agelamadins C-E (212-214) (Figure 37) are also present in this sponge [84]. Antifungal activity is displayed against Cryptococcus neoformans by agelamadins A (98), B (99), C (212), and E (214) (IC50 8.0, 4.0, 32, $32 \mu \mathrm{g} / \mathrm{mL}$, respectively $[54,84]$.

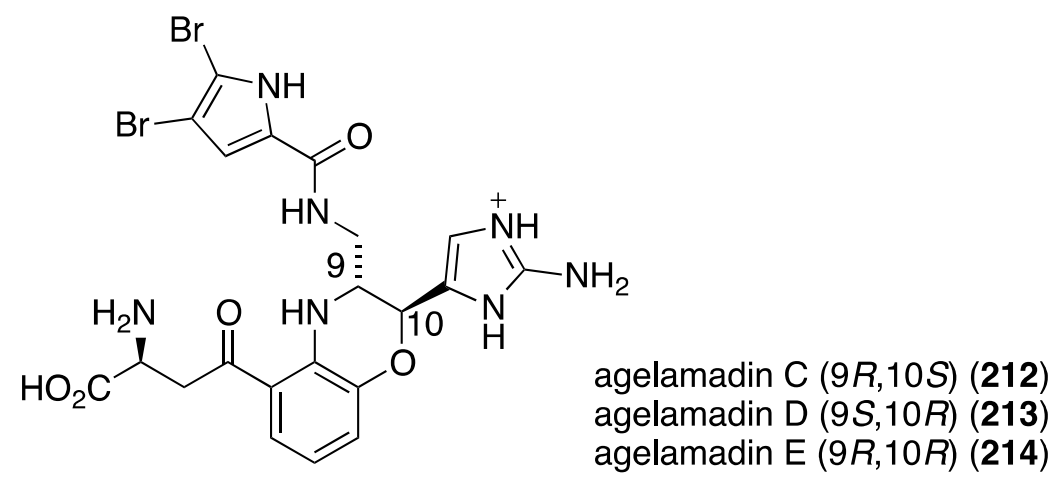

Figure 37. Structures of agelamadins C-E (212-214) from the sponge Agelas sp. SS-162 [84].

Further examination of Agelas spp. (SS-162 and SS-156) sponges from Okinawa reveals the presence of nagelamides U-W (216-218) [85], X-Z (219-221) [86], 2-debromonagelamide U (222), 2-debromomukanadin (223), and 2-debromonagelamide P (224) [87] (Figure 38). Antifungal activity against several fungi is summarized in Table 7, for which nagelamide $Z$ (221) shows significant activity towards all four fungi.

Marine algae can exhibit antifungal activity and several recent examples are described. The red alga Laurencia composita, collected from Pingtan Island, China, has afforded novel chamigranes, the laurecomins A-D (225-228) (Figure 39) [88]. Of these, laurecomin B (226) is antifungal towards Colletotrichum lagenarium (inhibitory diameter of $10 \mathrm{~mm}$ ).

A collection of Laurencia okamurai from Nanji Island, China, has furnished several new

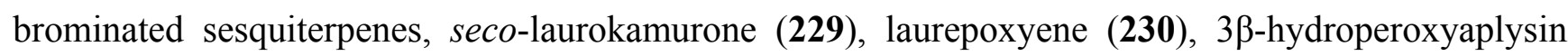
(231), 3 $\alpha$-hydroperoxy-3-epiaplysin (232), 8,10-dibromoisoaplysin (233), and laurokamurene D (234) (Figure 40) [89]. Antifungal activity of $\mathbf{2 3 0}-\mathbf{2 3 3}$ is tabulated in Table 8. 
<smiles>[R]C1(NC(N)=[NH2+])C[C@H](CNC(=O)c2cc(Br)c(Br)[nH]2)N(CCS(=O)(=O)[O-])C1=O</smiles>

nagelamide $U(R=\beta-H)(216)$ nagelamide $V(R=\alpha-H)(217)$<smiles>[R16][Z20](=O)[C@H](NC(=O)c1cc(Br)c(Br)[nH]1)C(=O)N[C@H](/C=C/c1c[nH]c(=[NH2+])[nH]1)c1[nH]c(=[NH2+])[nH]c1/C=C/CNC(=O)c1cc(Br)c(Br)[nH]1</smiles><smiles></smiles>

2-debromomukanadin G (223)<smiles></smiles>

nagelamide W (218)<smiles>NC(=[NH2+])NC1CC(CNC(=O)c2cc(Br)c[nH]2)N(CCS(=O)(=O)[O-])C1=O</smiles>

2-debromonagelamide $U$ (222)

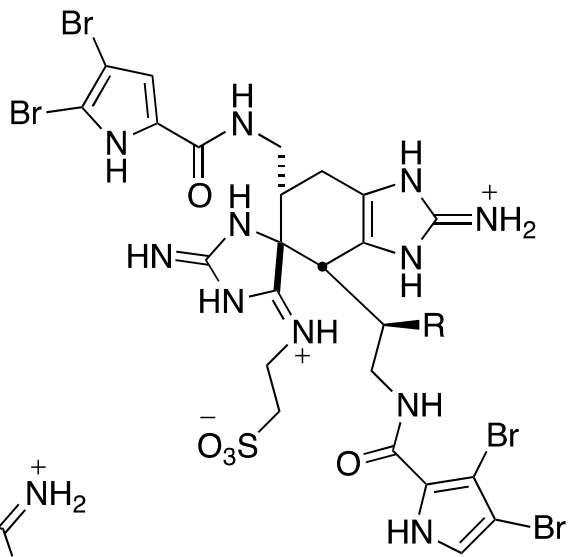

nagelamide $X(R=O H)(\mathbf{2 1 9})$ nagelamide $Y(R=H)(220)$

Figure 38. Structures of nagelamides $U-Z$ (216-221) and 222-224 from Agelas spp. sponges [85-87].

Table 7. Antifungal activity of nagelamides U-Z (216-221) and 222-224 [85-87].

\begin{tabular}{lcccccccc}
\hline & \multicolumn{10}{c}{ Compound $\left(\mathbf{I C}_{\mathbf{5 0}} \boldsymbol{\mu} \mathbf{g} / \mathbf{m L}\right)$} \\
\hline \multicolumn{1}{c}{ Fungus } & $\mathbf{2 1 6}$ & $\mathbf{2 1 8}$ & $\mathbf{2 1 9}$ & $\mathbf{2 2 0}$ & $\mathbf{2 2 1}$ & $\mathbf{2 2 2}$ & $\mathbf{2 2 3}$ & $\mathbf{2 2 4}$ \\
\hline Candida albicans & 4 & 4 & 2.0 & 2.0 & 0.25 & - & - & - \\
Trichophyton mentagrophytes & - & - & 16 & $<32$ & 4.0 & 16 & - & 32 \\
Cryptococcus neoformans & - & - & $<32$ & $<32$ & 2.0 & 32 & 32 & - \\
Aspergillus niger & - & - & 32 & $<32$ & 4.0 & - & - & - \\
\hline
\end{tabular}<smiles>C=C1CC[C@@H](C)C[C@]1(C)CC1C(C)=CCC1C</smiles>

laurecomin A (225)<smiles>C=C1CC[C@@H](Br)C[C@@]12C=CC(C)(O)CC2</smiles>

laurecomin B (226)<smiles>CC1=C(C[C@@]2(C)C(C)=C(C)CC2(C)C)C(C)(C)[C@H](Br)CC1</smiles>

laurecomin C (227)<smiles>CC1(C)C(=O)[C@@H](O)[C@@]2(CC1O)C(C)(C)C(=O)[C@H](O)[C@H]1O[C@@]12C</smiles>

laurecomin D (228)

Figure 39. Structures of laurecomins A-D (225-228) from the red alga Laurencia composita [88]. 
<smiles>COc1cc(O)c(C(=O)CC[C@H](C)C(C)(C)O)cc1Br</smiles>

seco-laurokamurone (229)<smiles>Cc1cc2c(cc1Br)[C@@]1(C)CC[C@](C)(O)[C@@]1(C)O2</smiles>

3 $\alpha$-hydroperoxyaplysin (232)<smiles>COc1cc(O)c([C@]2(C)CC[C@]3(C)O[C@]32C)cc1Br</smiles>

laurepoxyene (230)<smiles>Cc1c(Br)cc2c(c1Br)O[C@]1(CBr)[C@@H](C)CC[C@@]21C</smiles>

8,10-dibromoisoaplysin (233)<smiles>Cc1cc2c(cc1Br)[C@@]1(C)CC[C@](C)(O)[C@@]1(C)O2</smiles>

3ß-hydroperoxyaplysin (231)<smiles>COc1cc(Br)c(C2(O)CC[C@@H](C)C2(C)C)cc1Br</smiles>

laurokamurene D (234)

Figure 40. Structures of brominated sesquiterpenes 229-234 from the red alga Laurencia okamurai [89].

Table 8. Antifungal activity of brominated sesquiterpenes 230-233 from the red alga Laurencia okamurai [89].

\begin{tabular}{lcccccc}
\hline & \multicolumn{6}{c}{ Compound $^{\text {a }}$} \\
\hline \multicolumn{1}{c}{ Fungus } & $\mathbf{2 3 0}$ & $\mathbf{2 3 1}$ & $\mathbf{2 3 2}$ & $\mathbf{2 3 3}$ & Amphotericin B $^{\mathbf{b}}$ & Fluconazole $^{\mathbf{b}}$ \\
\hline Cryptococcus neoformans (32609) & $>64$ & 4 & 8 & $>64$ & 1 & 1 \\
Candida glabrata (537) & 2 & 4 & $>64$ & $>64$ & 2 & 1 \\
Trichophyton rubrum & 32 & 16 & $>64$ & $>64$ & 1 & $>64$ \\
Aspergillus fumigatus (07544) & $>64$ & $>64$ & $>64$ & $>64$ & 2 & 8 \\
\hline \multicolumn{7}{c}{${ }^{\mathrm{a}} \mathrm{MIC}_{50} \mu \mathrm{g} / \mathrm{mL}^{\mathrm{b}}{ }^{\mathrm{b}}$ Positive controls. }
\end{tabular}

The red alga Symphyocladia latiuscula from the coast of Qingdao, China, is a rich source of brominated phenols, and several new examples have been discovered (235-245) (Figure 41) [90-92]. Bromocatechols 235, 242, and 244 display moderate activity against Candida albicans (MIC 37.5, 10, and $25 \mu \mathrm{g} / \mathrm{mL}$, respectively) [90-92].

Weak antifungal activity is observed for gemmacolides T-Y (7-12) against Microbotryum violaceum and Septoria tritici, in the zone of inhibition ranging from 9.5-17 $\mathrm{mm}$ [31]. Two of the Synoicum sp. ascidian eudistomins, $\mathrm{Y}_{2}(\mathbf{1 3 2})$ and the non-brominated $\mathrm{Y}_{1}$, show potent to moderate activity against Candida albicans (MIC 6.25 and $50 \mu \mathrm{g} / \mathrm{mL}$, respectively) [65]. The other eudistomins $\mathrm{Y}_{3}-\mathrm{Y}_{7}$ are inactive against the four fungal strains tested. A study of the bryozoan Chartella membranaceatruncata, collected in Kandalaksha Bay, the White Sea, resulted in the characterization of 2,4,7-tribromotryptamine (246) (Figure 42), which displays potent activity towards Candida albicans and Saccharomyces cereviseae, although this result was not quantified [93]. 
<smiles>CS(=O)Cc1c(Br)c(O)c(O)c(Br)c1Br</smiles><smiles>O=C(O)C[C@H](C(=O)O)C(=Cc1c(Br)c(O)c(O)c(Br)c1Br)C(=O)O</smiles>

235 symphyocladin $\mathrm{A}(E, \mathrm{R}=\mathrm{H})(\mathbf{2 3 6})$ symphyocladin $B(Z, R=H)(237)$ symphyocladin $C(E, \mathrm{R}=\mathrm{Me})(\mathbf{2 3 8})$ symphyocladin $D(Z, R=M e)(239)$<smiles>O=C(O)/C=C(\C(=O)O)C(Cc1c(Br)c(O)c(O)c(Br)c1Br)C(=O)O</smiles>

symphyocladin E (240)<smiles>O=C(O)[C@@H]1CCC(=O)N1Cc1c(Br)c(O)c(O)c(Br)c1Br</smiles>

symphyocladin F (241)<smiles>O=C(NCc1c(Br)c(O)c(O)c(Br)c1Br)NCc1c(Br)c(O)c(O)c(Br)c1Br</smiles>

symphyocladin $\mathrm{G}$ (242)<smiles>O=C1CCCN1Cc1c(Br)c(O)c(O)c(Br)c1Cc1c(Br)c(O)c(O)c(Br)c1Br</smiles>

243<smiles>[R]c1c(Br)c(O)c(O)c(Br)c1CN(CCCC(C)=O)C(=O)NCc1c(Br)c(O)c(O)c(Br)c1Br</smiles>

Figure 41. Structures of symphyocladins $A-G(\mathbf{2 3 6}-\mathbf{2 4 2})$ and other bromophenols from the red alga Symphyocladia latiuscula [90-92].<smiles>NCCc1c(Br)[nH]c2c(Br)ccc(Br)c12</smiles>

246

Figure 42. Structure of 2,4,7-tribromotryptamine (246) from the bryozoan Chartella membranaceatruncata [93].

Several marine-derived bacteria have antifungal properties, such as strepchloritide B (47), from Streptomyces sp. OUCMDZ-1703, towards Candida albicans (13 $\pm 0.5 \mathrm{~mm}$ inhibitory diameter zone) [42], and the extraordinarily complex forazoline A (247), from Actinomadura sp. cultivated from the ascidian Ecteinascidia turbinata, towards Candida albicans (MIC $16 \mu \mathrm{g} / \mathrm{mL}$ ) [94]. This unique marine polyketide is also active in vivo in a disseminated candidiasis model in mice, with no toxicity. This important antifungal compound may prove to be a clinical candidate to treat Candida albicans fungal infections in humans such as candidiasis, which affects some 400,000 people annually with a mortality rate of $46 \%-75 \%$ [95]. Indeed, fungal infections of all types cause 1.5 million deaths per year worldwide [96]. 


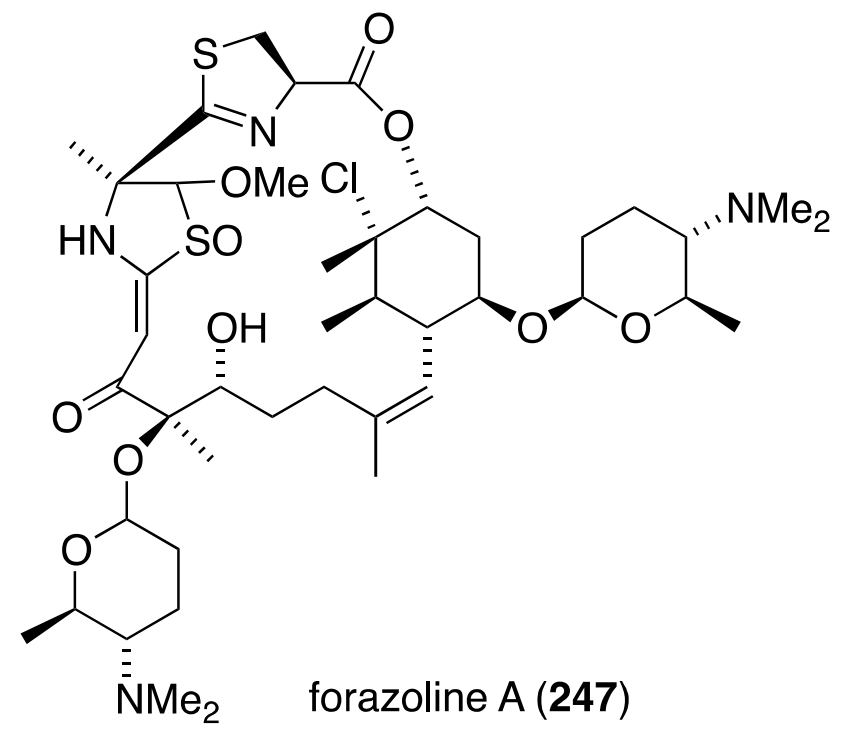

Figure 43. Structure of forazoline A (247) from Actinomadura sp. [94].

The fungal metabolite isochromophilone XI (164), from Bartalinia robillardoides, is active against the fungus Trichophyton rubrum ( $\mathrm{IC}_{50} 41.5 \mu \mathrm{M}$ ), but not against Candida albicans and Septoria tritici [71]. The Baltic Sea cyanobacterium Anabaena cylindrica Bio33, cultivated in the laboratory, has provided the antifungal lipopeptides balticidins A-D (248-251) (Figure 44) [97,98]. These complex metabolites are active towards Candida maltosa with inhibition zones for balticidins A-D of 12, 15, 9, and $18 \mathrm{~mm}$, respectively [97]. Antifungal activity with these compounds is also observed against C. albicans, Candida krusei, Aspergillus fumigatus, Microsporum gypseum, Mucor sp., and Microsporum canis. No antibacterial activity is observed for these compounds.

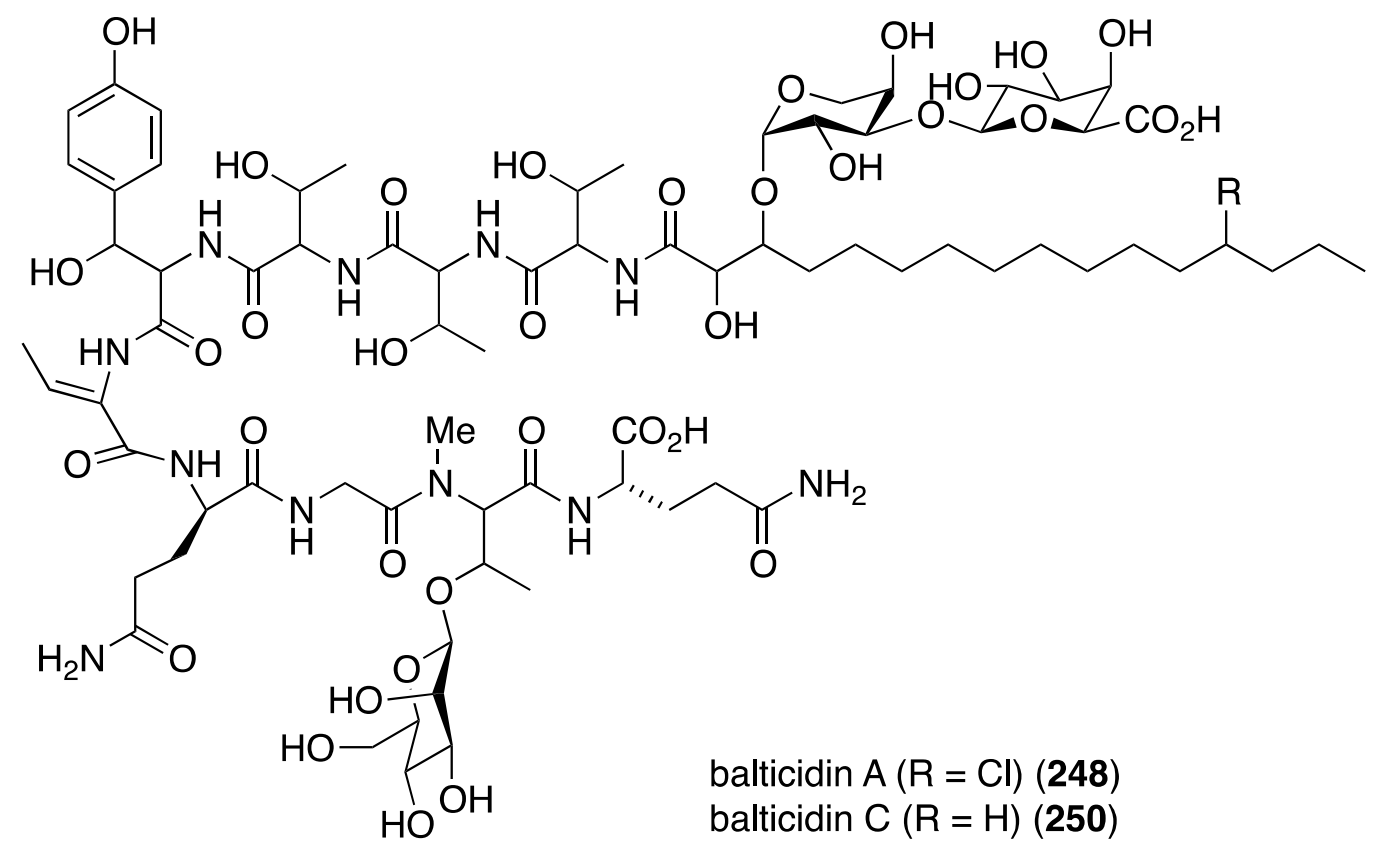

Figure 44. Cont. 


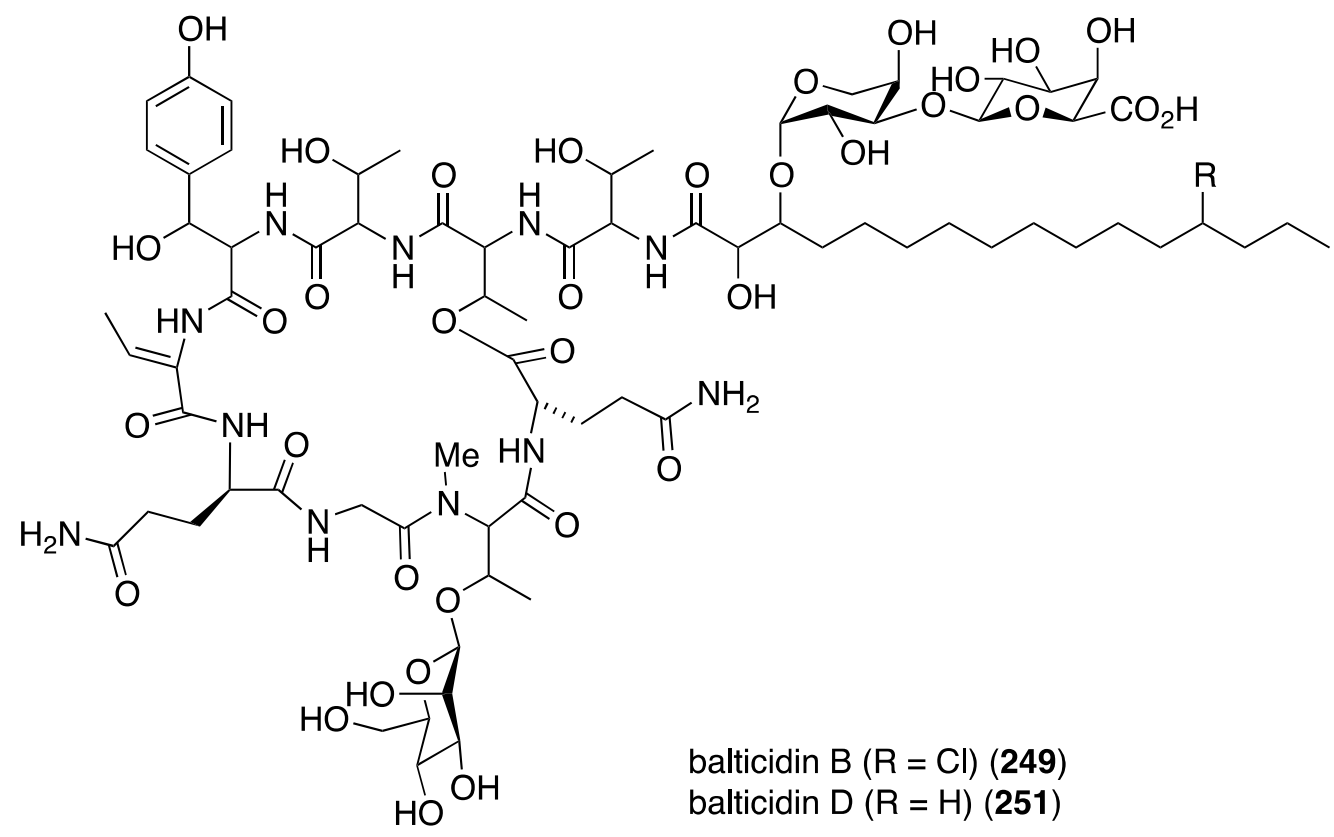

Figure 44. Structures of balticidins A-D (248-251) from the cyanobacterium Anabaena cylindrica Bio33 [97,98].

\section{Antiparasitic Activity}

The parasitic diseases malaria, leishmaniasis, echinococcus, Chagas disease (American trypanosomiasis), onchocerciasis ("river blindness"), dracunculiasis ("guinea worm disease"), trypanosomiasis ("sleeping sickness"), schistosomiasis, lymphatic filariasis (elephantiasis), and others in tropical and sub-tropical regions put billions of people at risk and account for millions of illnesses and deaths annually [99-104]. The need for new drugs to combat these parasite vectors is paramount, and a number of newly isolated halogenated marine natural products display antiparasitic activity.

A study of the Australian sponge Pseudoceratina sp. has yielded the new psammaplysin $\mathrm{H}(\mathbf{2 5 2})$ in addition to the known psammaplysins G (253) and F (254) (Figure 45) [104]. Compared to the latter two metabolites, 252 displays potent in vitro antimalarial activity against the chloroquine-sensitive (3D7) line of Plasmodium falciparum ( $\operatorname{IC}_{50}(\mu \mathrm{M}), 252$ : $0.41 \pm 0.1$; 253: $5.22 \pm 1.6$; 254: $1.92 \pm 1.1$ ), and minimal toxicity towards the mammalian cell lines HEK293 and HepG2, relative to 253 and 254 (selectivity index $\geq 97$ ).<smiles>[R]CCc1cc(Br)c(OCCCNC(=O)C2=NO[C@]3(CC(Br)=C(OC)C(Br)=CO3)[C@H]2O)c(Br)c1</smiles>

psammaplysin $\mathrm{H}\left(\mathrm{R}=\stackrel{+}{\mathrm{N}} \mathrm{Me}_{3}\right)(\mathbf{2 5 2})$ psammaplysin $\mathrm{G}\left(\mathrm{R}=\mathrm{N}(\mathrm{Me}) \mathrm{CONH}_{2}\right)(\mathbf{2 5 3})$ psammaplysin $\mathrm{F}(\mathrm{R}=\mathrm{NHMe})(\mathbf{2 5 4})$

Figure 45. Structures of psammaplysins H (252), G (253), and F (254) from the sponge Pseudoceratina sp. [104]. 
The Balinese sponge Aplysinella strongylata is the repository of 21 new psammaplysins (255-275) and six previously known analogues (Figure 46) [105]. Of those compounds tested (255, 256, 258, 259, 263, 269, and 273) against the 3D7 Plasmodium falciparum parasite, 19-hydroxypsammaplysin E (255) displays the highest activity ( $\mathrm{IC}_{50} 6.4 \mu \mathrm{M}$ ).

A collection of the sponge Suberea ianthelliformis has yielded five new bromotyrosines, araplysillin N20 formamide (276), araplysillin N20 formamide $N$-oxide (277), and araplysillins IV-VI (278-280) (Figure 47) in addition to 13 known brominated analogues [106]. Of the new metabolites, 276 and 277 show moderate activity against both chloroquine-resistent (FcB-1) strain of Plasmodium falciparum ( $\mathrm{IC}_{50} 3.6$ and $5.0 \mu \mathrm{M}$, respectively) and the chloroquine-sensitive (3D7) strain ( $\mathrm{IC}_{50} 7.0$ and $4.1 \mu \mathrm{M}$, respectively).<smiles>COC1=C(Br)C[C@]2(OC=C1Br)ON=C(C(=O)NCCCOc1c(Br)cc(C(O)CNC=C3C(=O)C=CC3=O)cc1Br)[C@H]2O</smiles>

19-hydroxypsammaplysin E (255)<smiles>COC1=C(Br)C[C@]2(OC=C1Br)ON=C(C(=O)NCCCOc1c(Br)cc(C3CNC(=O)O3)cc1Br)[C@H]2O</smiles>

psammaplysin L (258)<smiles>[R]c1cc(Br)c(OCCCNC(=O)C2=NO[C@@]3(C2)CC(Br)=C(OC)C(Br)=CO3)c(Br)c1</smiles>

psammaplysin $\mathrm{K}(\mathrm{R}=\mathrm{CHO})(\mathbf{2 5 6})$ psammaplysin $\mathrm{K}$ dimethoxy acetal $\left(\mathrm{R}=\mathrm{CH}(\mathrm{OMe})_{2}\right)$

$(257)$<smiles>COC1=C(Br)[C@@H](O)[C@]2(OC=C1Br)ON=C(C(=O)NCCCOc1c(Br)cc(CCNC=O)cc1Br)[C@@H]2O</smiles>
psammaplysin M (259)<smiles>COC1=C(Br)C[C@@]2(OC=C1Br)ON=C(C(=O)NCCCOc1c(Br)cc(CCNC(=O)CCCCC(C)C)cc1Br)[C@H]2O</smiles>

psammaplysin N (260)

Figure 46. Cont. 
<smiles>[R]C(CNC(=O)CCCCCC(C)CC)c1cc(Br)c(OCCCNC(=O)C2=NO[C@]3(C2)OC=C(Br)C(OC)=C(Br)[C@@H]3O)c(Br)c1</smiles><smiles>[R]C(CNC(=O)CCCCCC=CCCCC(C)C)c1cc(Br)c(OCCCNC(=O)C2=NO[C@@]3(C2)CC(Br)=C(OC)C(Br)=CO3)c(Br)c1</smiles>

psammaplysin $U(R=H, n=5, m=1)(271)$

19-hydroxypsammaplysin $\mathrm{U}(\mathrm{R}=\mathrm{OH}, \mathrm{n}=5, \mathrm{~m}=1)(272)$<smiles>[R]C(CNC(=O)CCCCC=CCCCCC)c1cc(Br)c(OCCCNC(=O)C2=NO[C@@]3(C2)CC(Br)=C(OC)C(Br)=CO3)c(Br)c1</smiles>

psammaplysin $\mathrm{V}(\mathrm{R}=\mathrm{H}, \mathrm{n}=5, \mathrm{~m}=1)(\mathbf{2 7 3})$

psammaplysin $W(R=H, n=8, m=1)(274)$

19-hydroxypsammaplysin $\mathrm{W}(\mathrm{R}=\mathrm{OH}, \mathrm{n}=8, \mathrm{~m}=1)(\mathbf{2 7 5})$

Figure 46. Structures of psammaplysins 255-275 from the sponge Aplysinella strongylata $[105]$. 
<smiles>[R]N([R])CCc1cc(Br)c(OCCCNC(=O)C2=NO[C@]3(C=C(Br)C(OC)=C(Br)[C@@H]3O)C2)c(Br)c1</smiles>

araplysillin $\mathrm{N} 20$ formamide $\left(\mathrm{R}^{1}=\mathrm{H}, \mathrm{R}^{2}=\mathrm{CHO}\right)(\mathbf{2 7 6})$ araplysillin $\mathrm{N} 20$ hydroxyformamide $\left(\mathrm{R}^{1}=\mathrm{OH}, \mathrm{R}^{2}=\mathrm{CHO}\right)(\mathbf{2 7 7})$ araplysillin IV $\left(\mathrm{R}^{1}=\mathrm{H}, \mathrm{R}^{2}=\mathrm{CO}\left(\mathrm{CH}_{2}\right)_{8} \mathrm{CH}(\mathrm{Me})\left(\mathrm{CH}_{2}\right)_{5} \mathrm{Me}\right)(\mathbf{2 7 8})$ araplysillin $\mathrm{V}\left(\mathrm{R}^{1}=\mathrm{H}, \mathrm{R}^{2}=\mathrm{CO}\left(\mathrm{CH}_{2}\right)_{10} \mathrm{CH}(\mathrm{Me})\left(\mathrm{CH}_{2}\right)_{5} \mathrm{Me}\right)(\mathbf{2 7 9})$

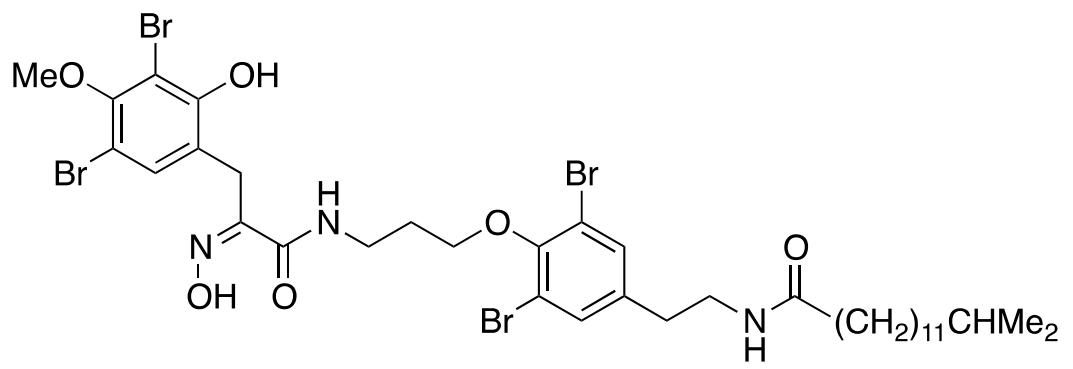

araplysillin VI (280)

Figure 47. Structures of araplysillins 276-280 from the sponge Suberea ianthelliformis [106].

A specimen of Verongula rigida from the coast of Columbia has afforded nine previously known bromotyrosines, and two of these, purealidin B and 11-hydroxyaerothionin, display selective antiparasitic activity at 10 and $5 \mu \mathrm{M}$ against Leishmania panamensis and Plasmodium falciparum parasites, respectively [107]. The Australian sponge Iotrochota sp. contains the two antitrypanosomal compounds, iotrochamides A (281) and B (282) (Figure 48). Both compounds exhibit moderate activity against Trypanosoma brucei brucei (IC50 3.4 and $4.7 \mu \mathrm{M}$, respectively) [108].<smiles>COC(=Cc1ccccc1)C(=O)N[C@@H](CO)Cc1ccc(O)cc1</smiles>

iotrochamide A (281)<smiles>CO/C(=C\c1ccccc1)C(=O)N[C@@H](CO)Cc1c[nH]c2ccccc12</smiles>

iotrochamide B (282)

Figure 48. Structures of iotrochamides A (281) and B (282) from the sponge Iotrochota sp. [108].

Another Australian marine sponge, Zyzzya sp., has furnished the new tsitsikammamine C (283), along with six previously known structurally related brominated alkaloids (Figure 49) [109]. This novel bispyrroloiminoquinone displays extraordinarily potent in vitro antimalarial activity towards both chloroquine-sensitive (3D7) and chloroquine-resistant (Dd2) Plasmodium falciparum with values 
of IC50 13 and $18 \mathrm{nM}$, respectively. The selectivity index against HEK293 cells is $>200$. Known alkaloids makaluvamines $\mathrm{J}, \mathrm{G}$, and $\mathrm{L}$ are slightly less active than tsitsikammamine $\mathrm{C}$ in both screens.

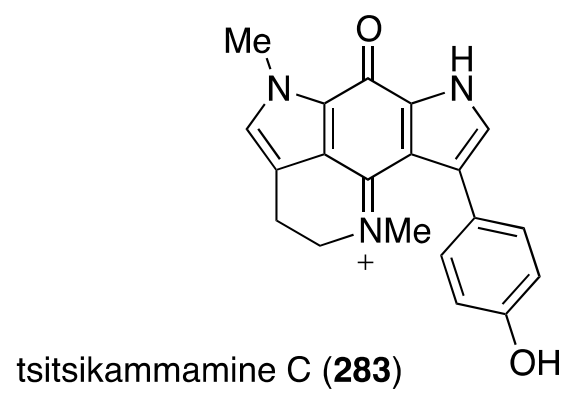

Figure 49. Structure of tsitsikammamine C (283) from the sponge Zyzzya sp. [109].

A suite of new manadoperoxides E-K (284-290) and peroxyplakoric ester C (291) were isolated from the sponge Plakortis cfr. lita (Figure 50), two of which contain chlorine $(\mathbf{2 8 9}, \mathbf{2 9 0})$, in addition to several known manadoperoxides [110]. Manadoperoxides I (288) and K (290) display the greatest activity of the new compounds tested against Trypanosoma brucei rhodesiense ( $\mathrm{IC}_{50} 0.062$ and $0.087 \mu \mathrm{g} / \mathrm{mL}$, respectively) and Leishmania donovani ( $\mathrm{IC}_{50} 0.633$ and $1.89 \mu \mathrm{g} / \mathrm{mL}$, respectively). However, the known manadoperoxide B has IC50 values of 0.003 and $0.589 \mu \mathrm{g} / \mathrm{mL}$, respectively.<smiles>CC[C@H](O)/C(C)=C/[C@H](O)CCC[C@]1(OC)C[CH][CH]OO1</smiles>

manadoperoxide $E \mathbf{( 2 8 4 )}$<smiles>COC(C)(/C=C/CCC[C@]1(OC)C[C@H](C)[C@@H](I)OO1)C(C)O</smiles>

manadoperoxide $\mathrm{F}$ (285)<smiles>COC(=O)OOC(C)(C)C</smiles>

manadoperoxide $\mathrm{G}$ (286)<smiles>CCCC(C=O)CCCCC[C@]1(OC)C[C@H](C)[C@@H](CC(C)=O)OO1</smiles>

manadoperoxide $\mathrm{H}$ (287)

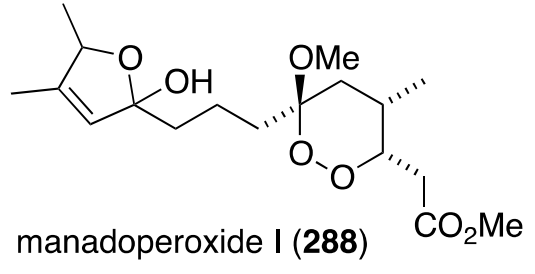

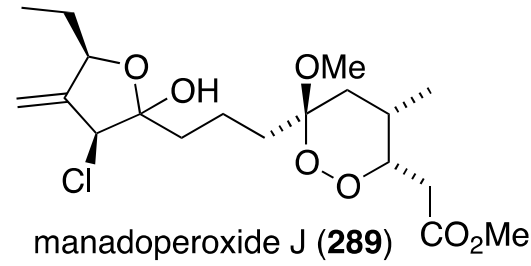<smiles>CC[C@H]1O[C@H](CCC[C@]2(OC)C[C@H](C)[C@@H](CCOC)OO2)[C@@H](Cl)[C@@]1(C)OC</smiles>

manadoperoxide $\mathrm{K}(\mathbf{2 9 0})$<smiles>CO[C@H](C)[C@H]1CC[C@@](CCC/C=C/C(C)=O)(OC)OO1</smiles>

peroxyplakoric ester C (291)

Figure 50. Structures of manadoperoxides E-K (284-290) and peroxyplakoric ester C (291) from the sponge Plakortis cfr. lita [110].

The previously described bromophycoic acids (127-131) display activity against the malaria parasite (3D7 strain) Plasmonium falciparum, with the peroxy bromophycoic acid C (129) being the most active: $\mathrm{IC}_{50} 8.7 \mu \mathrm{M}$ [64]. For comparison, the known macrolide bromophycolide A shows $\mathrm{IC}_{50}$ $0.5 \mu \mathrm{M}[111]$ and the positive controls chloroquine and artemisin show $\mathrm{IC}_{50} 0.0058$ and $0.0062 \mu \mathrm{M}$, 
respectively [64]. The New Zealand ascidian Pseudodistoma opacum contains four new brominated $\beta$-carboline alkaloids, (-)-7-bromohomotrypargine (292) and opacalines A-C (293-295) (Figure 51) [112]. Opacalines B and C show activity against several parasites (Table 9). Some non-brominated synthetic analogues have comparable antiparasitic activity. For example, debromoopacaline $\mathrm{C}$ shows $\mathrm{IC}_{50} 7.7 \mu \mathrm{M}$ against Trypanosoma brucei rhodesiense, a parasite that causes human African trypanosomiasis.

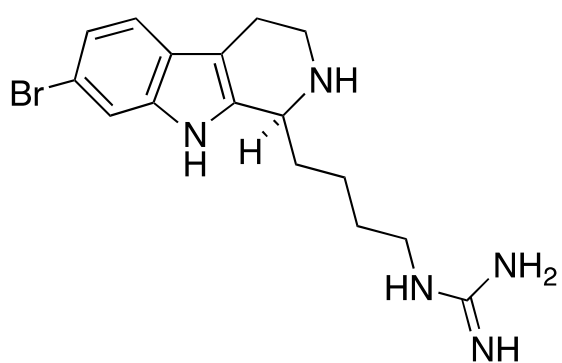

7-bromohomotrypargine (292)<smiles>N=C(N)NCCCc1nccc2c1[nH]c1cc(Br)ccc12</smiles>

opacaline $A(n=2)(293)$

opacaline B $(n=2)(294)$ opacaline C $(n=1)(295)$

Figure 51. Structures of 292 and opacalines A-C (293-295) from the ascidian Pseudodistoma opacum [112].

Table 9. Antiparasitic activity of opacalines B (294) and C (295) and positive controls ( $\left.\mathrm{IC}_{50} \mu \mathrm{M}\right)$.

\begin{tabular}{lcccccc}
\hline \multicolumn{1}{c}{ Parasite } & $\mathbf{2 9 4}$ & $\mathbf{2 9 5}$ & Melarsoprol & Benznidazole & Miltefosine & Chloroquine \\
\hline $\begin{array}{l}\text { Trypanosoma brucei } \\
\text { rhodesiense }\end{array}$ & 30 & 27 & 0.005 & - & - & - \\
Trypanosoma cruzi & 86 & 107 & - & 1.8 & - & - \\
Leishmania donovani & 130 & 101 & - & - & 0.53 & - \\
Plasmodium falciparum & 2.5 & 4.5 & - & - & - & 0.28 \\
\hline
\end{tabular}

The novel kororamide A (296) from the Australian bryozoan Amathia tortuosa, which exists as a mixture of interconverting amide rotamers (Figure 52), has activity against Plasmodium falciparum; $70 \%$ growth inhibition at $20 \mu \mathrm{M}$ for the chloroquine-sensitive strain, but only $50 \%$ growth inhibition of $50 \%$ at $20 \mu \mathrm{M}$ for the chloroquine resistant strain [113].

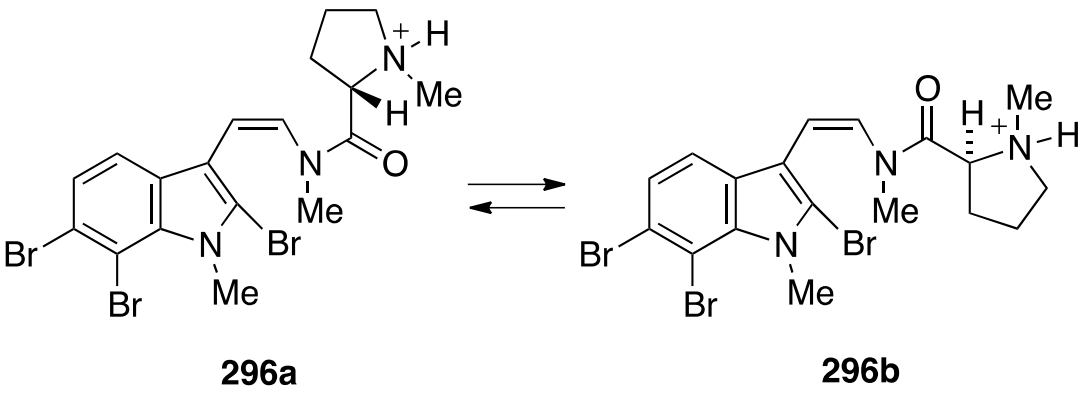

Figure 52. Structure of kororamide A (296) from the bryozoan Amathia tortuosa [113].

A Panamanian cyanobacterium, Oscillatoria sp., has afforded the novel polyketide lactones coibacins A-D (297-300) (Figure 53) [114]. Activity of these compounds is seen against the parasite 
Leishmania donovani axenic amastigotes, with coibacin A (297) being the most active, showing IC50 $2.4 \mu \mathrm{M}$. The coibacins were inactive to malaria and Chagas' disease.<smiles>C[C@H]1C[C@H]1/C=C/C=C/CC/C=C/C=C/[C@H]1CC=CC(=O)O1</smiles>

coibacin A (297)<smiles>CC(=CCl)CC=CC=CCC[C@H]1CC=CC(=O)O1</smiles>

coibacin C (299)<smiles>C[C@H]1C[C@H]1/C=C/CC/C=C/C=C/[C@H]1CC=CC(=O)O1</smiles>

coibacin B (298)<smiles>CC(=CCl)CC=CCCCC[C@H]1CC=CC(=O)O1</smiles>

coibacin D (300)

Figure 53. Structures of coibacins A-D (297-300) from the cyanobacterium Oscillatoria sp. [114].

\section{Antiviral Compounds}

In addition to harmful bacteria, fungi, and parasites, humans have to contend with lethal viruses, and the search for new antiviral compounds is intense. Although fewer in number than terrestrial sources, the marine environment has produced some antiviral active compounds. A review of antiviral lead compounds from sponges has appeared [115].

A collection of 11 well-known bromotyrosines that was isolated from the Columbian sponges Verongula rigida [107,116] and Aiolochoria crassa [117] were examined for in vitro inhibition of HIV-1 replication [118]. Of these 11, six inhibit HIV-1 replication at different steps. Aeroplysinin-1, purealidin $\mathrm{B}$, and 3-bromo-5-hydroxy-O-methyltyrosine inhibit the HIV-1 replication in a dose-dependent fashion, with a median maximum inhibition percentage of $74 \%$ at $20 \mu \mathrm{M}$ and $47 \%$ at $80 \mu \mathrm{M}$ (not cytotoxic at these concentrations). Aeroplysinin-1, 19-deoxyfistularin 3, purealidin B, fistularin 3, and 3-bromo-5-hydroxy- $O$-methyltyrosine efficiently inhibit the nuclear import. In addition, aeroplysinin-1, purealidin B, fistularin 3, 3-bromo-5-hydroxy-O-methyltyrosine, and 3,5-dibromo- $N, N, O, O$-tetramethyltyraminium inhibit X4 HIV-1 cell entry with an inhibition median percentage maximum of $2 \%-30 \%$ [118].

The marine-derived fungus Humicola fuscoatra has yielded three new chlorine-containing resorcyclic acid lactones, radicicols B-D (301-303) (Figure 54), in addition to the known radicicol (=monorden) and pochonins B, D, and N [119]. Of the three new radicicols, radicicol B (301) is the most active in the latent HIV-1 reactivation assay $\left(25 \%\right.$; $\left.\mathrm{EC}_{50} 24.9 \mu \mathrm{M}\right)$, but inferior to radicicol $(98 \%$; $\left.\mathrm{EC}_{50} 9.1 \mu \mathrm{M}\right)$, pochonin B $\left(98 \% \mathrm{EC}_{50} 39.6 \mu \mathrm{M}\right)$, and pochonin C (92\%; EC $\left.506.3 \mu \mathrm{M}\right)$. Those compounds lacking a conjugated carbonyl (Michael acceptor) are inactive. 
<smiles>C[C@H](C[C@H](O)[C@@H](O)/C=C\C=C/C(=O)Cc1c(Cl)c(O)cc(O)c1Cl)OC(=O)c1ccc(O)cc1O</smiles>

radicicol $\mathrm{B}(\mathbf{3 0 1})$<smiles>CO[C@H](C)CC(O)/C=C/C(O)C(O)CC(=O)Cc1c(Cl)c(O)cc(O)c1C(=O)O</smiles>

radicicol C (302)<smiles>CO[C@@H](C)CC(O)C1C=CC(CC(=O)Cc2c(Cl)c(O)cc(O)c2C(=O)O)O1</smiles>

radicicol D (303)

Figure 54. Structures of radicicols B-D (301-303) from Humicola fuscoatra [119].

Mangrove plants that grow in tropical and subtropical intertidal estuarine zones are a rich source of natural products including organohalogens [120]. The Chinese mangrove plant Aegicerus corniculatum has an associated fungus, Emericella sp., that produces six new isoindolones, emerimidines A (304) and $B$ (305), and emeriphenolicins A-D (306-309) (Figure 55) [121]. Of this collection only the non-halogenated emerimidines $A$ and $B$ display antiviral activity towards influenza $A$ virus $\left(\mathrm{H}_{1} \mathrm{~N}_{1}\right)$ replication in MDCK cells ( $\mathrm{IC}_{50} 42.07$ and $62.05 \mu \mathrm{g} / \mathrm{mL}$, respectively; ribavirin positive control: $24.60 \mu \mathrm{g} / \mathrm{mL})$.<smiles>[R]c1c(OC)cc2c(c1[R])CNC2=O</smiles>

emerimidine $A\left(R^{1}=O H, R^{2}=O M e\right)(304)$ emerimidine $B\left(R^{1}=\mathrm{OMe}, \mathrm{R}^{2}=\mathrm{OH}\right)(305)$<smiles>[R]c1cc2c(c(OC/C=C(/C)CC/C=C(/C)CC[C@H]([R1])C([R9])(C)C)c1[R])CNC2=O</smiles>

emeriphenolicin $A\left(R^{1}=R^{2}=O M e, R^{3}=C l, R^{4}=O H\right)(306)$ emeriphenolicin $B\left(R^{1}=\mathrm{OMe}, \mathrm{R}^{2}=\mathrm{R}^{4}=\mathrm{OH}, \mathrm{R}^{3}=\mathrm{Cl}\right)(307)$ emeriphenolicin $C\left(R^{1}=R^{2}=O M e, R^{3}=R^{4}=O H\right)(308)$<smiles>COc1c2c(cc(O)c1OCC=C(C)CCC=C(C)CCC=C(C)C)C(=O)NC2</smiles>

Figure 55. Structures of emerimidines A (304) and B (305), and emeriphenolicins A-D (306-309) [121].

The Indian Ocean ascidian Synoicum sp. has yielded the new rubrolide R (310) and the known rubrolide A (311) (isolated as the diacetates), along with the known cadiolide B (312) and prunolide A (313) (Figure 56) [122]. The latter two metabolites are active against the Japanese encephalitis virus at a concentration of $1 \mu \mathrm{g} / \mathrm{mL}$. 
<smiles>[R]C1=C(c2cc(Br)c(O)c(Br)c2)/C(=C/c2cc([R])c(O)c(Br)c2)OC1=O</smiles>

rubrolide $R\left(R^{1}=H, R^{2}=B r\right)(310)$ rubrolide $A\left(R^{1}=B r, R^{2}=H\right)(311)$<smiles>O=C1O/C(=C\c2cc(Br)c(O)c(Br)c2)C(c2cc(Br)c(O)c(Br)c2)=C1C(=O)c1cc(Br)c(O)c(Br)c1</smiles>

cadiolide B (312)<smiles>O=C1C=C(c2cc(Br)c(O)c(Br)c2)[C@@]2(O1)O[C@@]1(OC(=O)C=C1c1cc(Br)c(O)c(Br)c1)C(c1cc(Br)c(O)c(Br)c1)=C2c1cc(Br)c(O)c(Br)c1</smiles>

prunolide A (313)

Figure 56. Structures of 310-313 from the ascidian Synoicum sp. [122].

The marine cyanobacterium Trichodesmium erythraeum, collected in Singapore, has afforded the new aplysiatoxins, 3-methoxyaplysiatoxin (314) and 3-methoxydebromoaplysiatoxin (315) (Figure 57), in addition to the known aplysiatoxin, debromoaplysiatoxin, and anhydrodebromoaplysiatoxin [123]. Both 315 and anhydrodebromoaplysiatoxin display significant activity against the Chikungunya virus (CHIKV) in infected baby hamster kidney cells (BHK21), with $\mathrm{EC}_{50}$ values of 2.7 and $22.3 \mu \mathrm{M}$, respectively. Debromoaplysiatoxin is the most potent of these five compounds with $\mathrm{EC}_{50} 1.3 \mu \mathrm{M}$. The two brominated metabolites did not result in any significant inhibition at $10 \mu \mathrm{M}$.

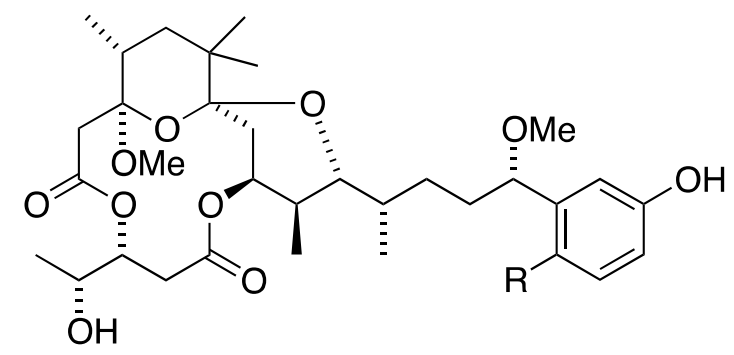

3-methoxyaplysiatoxin $(\mathrm{R}=\mathrm{Br})(\mathbf{3 1 4})$

3-methoxydebromoaplysiatoxin $(R=H)(315)$

Figure 57. Structures of aplysiatoxins 314 and 315 from the cyanobacterium Trichodesmium erythraeum [123].

Of several known polybromocatechols isolated from the Korean red alga Neorhodomela aculeata, lanosol (316) and 317 are active against the human rhinovirus HRV2, IC50 2.50 and $7.11 \mu \mathrm{g} / \mathrm{mL}$, respectively. The latter polybrominated diphenylmethane is also active towards HRV3, IC $504.69 \mu \mathrm{g} / \mathrm{mL}$ (Figure 58) [124]. The naturally occurring algae (Peyssonnelia sp.) and sponge (Hyatella intestinalis) metabolite peyssonol A (318) (Figure 58) has been evaluated, along with synthetic stereoisomers, against a recombinant HIV-1 strain (Rep-Rlue Sac II) [125]. Peyssonol A shows the most activity (EC50 $1 \mu \mathrm{M}$ ), with analogues 319-321 somewhat less active ( $\mathrm{IC}_{50} 2-4 \mu \mathrm{M}$ ). 
<smiles>OCc1cc(O)c(O)c(Br)c1Br</smiles>

lanosol (316)<smiles>COCc1cc(O)c(O)c(Br)c1Cc1cc(O)c(O)c(Br)c1Br</smiles>

317<smiles>C=C1CC[C@H]2C(C)(C)C(Br)CC[C@]2(C)[C@H]1Cc1cc(O)c(C=O)cc1O</smiles>

peyssonal A (318)

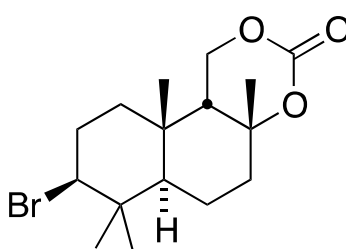

319<smiles>CC1(C)C(Br)CCC2(C)C1CCC(O)(O)[C@H]2CO</smiles>

320<smiles>O=Cc1cc(O)c(CC2CCCCC2)cc1O</smiles>

321

Figure 58. Structures of lanosol (316) and 317 from the red alga Neorhodomela aculeata [124] and peyssonol A (318) and synthetic analogues 319-321 [125].

\section{Antitumor Compounds}

Of enormous concern to all mankind is cancer - the inexorable transformation of normal cells and the proliferation of cancerous cells into tumors. The marine environment provides an array of metabolites active against cancer cells.

Amongst all marine life, sponges have afforded the vast majority of anti-tumor compounds. The Vietnamese sponge Penares sp. contains the novel alkaloids, 322 and $\mathbf{3 2 3}$ (Figure 59), the former of which is moderately cytotoxic to the human tumor cell lines HL-60 (lung) and HeLa (cervix), IC50 16.1 and $33.2 \mu \mathrm{M}$, respectively, whereas 323 is inactive [126].<smiles></smiles>

322

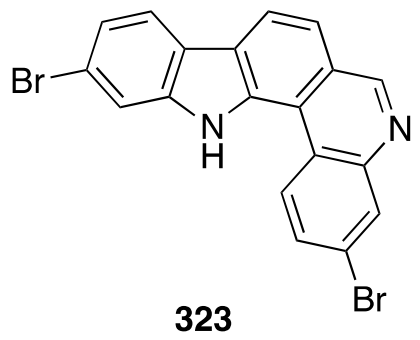

323

Figure 59. Structures of $\mathbf{3 2 2}$ and $\mathbf{3 2 3}$ from the sponge Penares sp. [126].

The novel polyketides, PM050489 (324) and PM060184 (325), were isolated from the Madagascan sponge Lithoplocamia lithistoides (Figure 60) [127]. Both are tubulin-binders, and show excellent growth inhibition against human tumor cells, including HT-29 (colon), A-549 (lung), and MDA-MB-231 (breast), with $\mathrm{GI}_{50}$ values of $0.46,0.38$, and 0.45 (324) and $0.42,0.59$, and $0.71(\mathbf{3 2 5}) \mathrm{nM}$, respectively. 


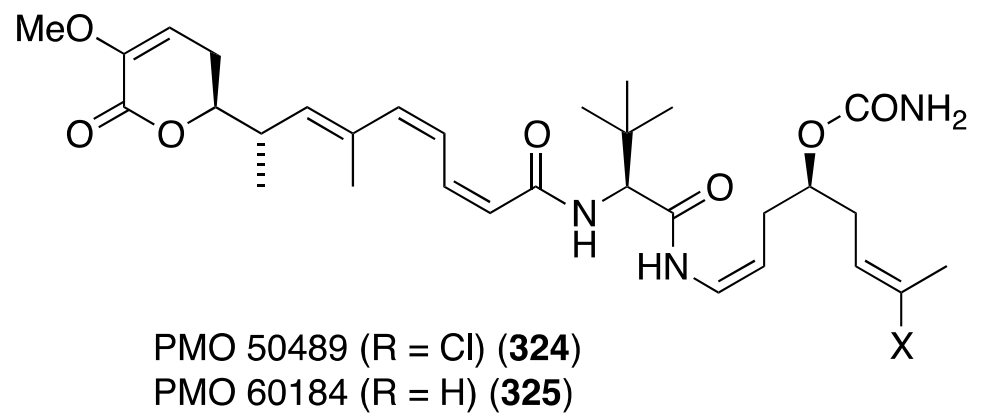

Figure 60. Structures of PM050489 (324) and PM060184 (325) from the sponge Lithoplocamia lithistoides [127].

The new sesterterpenoid phobaketals N (326) (Figure 61) isolated from a Korean Phorbas sp. sponge has potent cytotoxicity against the human pancreas cell line (Panc-1) and the human renal cell lines (A498 and $\mathrm{ACHN}$ ) with $\mathrm{IC}_{50} 11.4,18.7$, and $24.4 \mu \mathrm{M}$, respectively [128]. Of the two nonbrominated phorbaketals ( $\mathrm{L}$ and $\mathrm{M}$ ) also isolated from this sponge, only phorbaketal $\mathrm{L}$ shows cytotoxicity (A498, $17.3 \mu \mathrm{M})$.<smiles>C=C(CCC1OC1(C)C)[C@H](Br)[C@@H]1CC(C)=CC2(C=C(CO)[C@H]3CC(=O)C(C)=C[C@H]3O2)O1</smiles>

phorbaketal N (126)

Figure 61. Structure of phorbaketal N (326) from the sponge Phorbas sp. [128].

A Micronesian specimen of a Suberea sp. sponge has afforded four new psammaplysins (327-330) and four new ceratinamines (331-334) (Figure 62), along with nine previously known bromotyrosine analogues [129]. Whereas the ceratinamines are essentially devoid of cytotoxicity against a panel of human cancer cell lines, the psammaplysins are quite active (Table 10). Included in the table are some of the isolated known analogues and the positive control doxorubicin.

Two new brominated acetylenes, 335 and 336, were isolated from a collection of Haliclona sp. sponge living in Saudi Arabia waters (Figure 63) [130]. Both are active towards MCF-7 human breast cancer cells, IC50 32.5 and $50.8 \mu \mathrm{M}$, respectively, but not against HepG2 (human hepatocellular carcinoma), WI-38 (skin carcinoma), and Vero (African green monkey kidney).

Callyspongiolide (337) is a novel macrolide characterized from the Indonesian sponge Callyspongia sp. (Figure 64) [131]. This metabolite exhibits potent cytotoxicity against L5178Y mouse lymphoma cells, human Jurkat J16 T and Ramos B lymphocytes with IC50 values of 320, 70, and $60 \mathrm{nM}$, respectively. 
<smiles>[R]C(CNC=C1C(=O)CC(Cl)C1=O)c1cc(Br)c(OCCCNC(=O)C2=NOC3(CC(Br)=C(OC)C(Br)=CO3)[C@@H]2O)c(Br)c1</smiles>

psammaplysin $X(R=H)(\mathbf{3 2 7})$ 19-hydroxypsammaplysin $X(R=\mathrm{OH})(\mathbf{3 2 8})$<smiles>COC1=C(Br)C[C@]2(OC=C1Br)ON=C(C(=O)NCCCOc1c(Br)cc(CCNC=C3C(=O)CCC3=O)cc1Br)[C@@H]2O</smiles>
psammaplysin Y (329)<smiles>N#CC(=O)NCCCOc1c(Br)cc(CCNC=C2C(=O)CC(Cl)C2=O)cc1Br</smiles>

subereamide B (332)<smiles>COC1=C(Br)C[C@]2(OC=C1Br)ON=C(C(=O)NCCCOc1c(Br)cc(C(O)CNC=O)cc1Br)[C@@H]2O</smiles>

19-hydroxyceratinamide A (330)<smiles>N#CC(=O)NCCCOc1c(Br)cc(CCNC=C2C(=O)C=CC2=O)cc1Br</smiles>

subereamide A (331)<smiles>[R]C(CNC(=O)C(C)(C)CC(C)C)c1cc(Br)c(OCCCNC(C)=O)c(Br)c1</smiles>

subereamide $\mathrm{C}(\mathrm{R}=\mathrm{H})(\mathbf{3 3 3})$

12-hydroxysubereamide $\mathrm{C}(\mathrm{R}=\mathrm{OH})(334)$

Figure 62. Structures of psammaplysins 327-330 and ceratinamines 331-334 from the Suberea sp. sponge [129].

Table 10. Growth inhibition $\left(\mathrm{GI}_{50} \mu \mathrm{M}\right)$ of psammaplysins and known analogues against human cancer cell lines [129].

\begin{tabular}{lcccccc}
\hline \multicolumn{1}{c}{ Compound } & HCT-15 & PC-3 & ACHN & MDA-MB-21 & NUGC-3 & NIC-H23 \\
\hline psammaplysin X (327) & 3.3 & 2.3 & 3.3 & 1.2 & 3.5 & 6.4 \\
10-hydroxypsammaplysin X (328) & 3.5 & 2.1 & 2.5 & 0.8 & 4.0 & 3.5 \\
psammaplysin A & 3.9 & 6.9 & 5.1 & 4.3 & 3.8 & 12.4 \\
psammaplysin B & 4.0 & 2.7 & 1.6 & 0.53 & 2.5 & 3.7 \\
psammaplysin D & 24 & 25 & 27 & 21 & 26 & 27 \\
psammaplysin E & 7.4 & 3.7 & 10.3 & 3.9 & 4.0 & 7.0 \\
19-hydroxypsammaplysin E & 3.8 & 1.4 & 2.3 & 0.51 & 2.3 & 3.6 \\
moloka'iamine & $>70$ & $>70$ & $>70$ & $>70$ & $>70$ & $>70$ \\
7-hydroxymoloka'iamine & $>70$ & $>70$ & $>70$ & $>70$ & $>70$ & $>70$ \\
ceratinamine & $>70$ & $>70$ & $>70$ & $>70$ & $>70$ & $>70$ \\
hydroxyceratinamine & $>70$ & $>70$ & $>70$ & $>70$ & $>70$ & $>70$ \\
doxorubicin & 1.4 & 0.52 & 2.0 & 1.8 & 0.51 & 1.9 \\
\hline
\end{tabular}




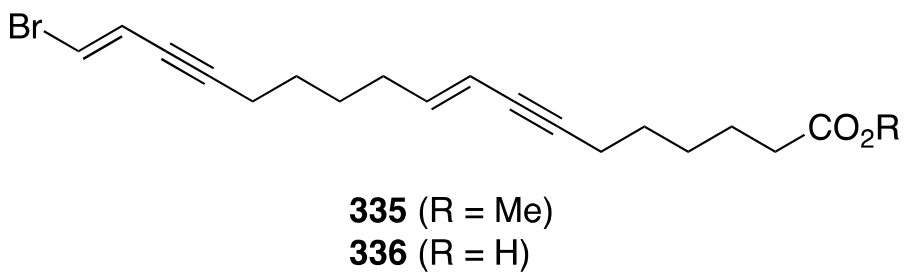

Figure 63. Structures of brominated acetylenes 335 and $\mathbf{3 3 6}$ from the Haliclona sp. sponge [130].

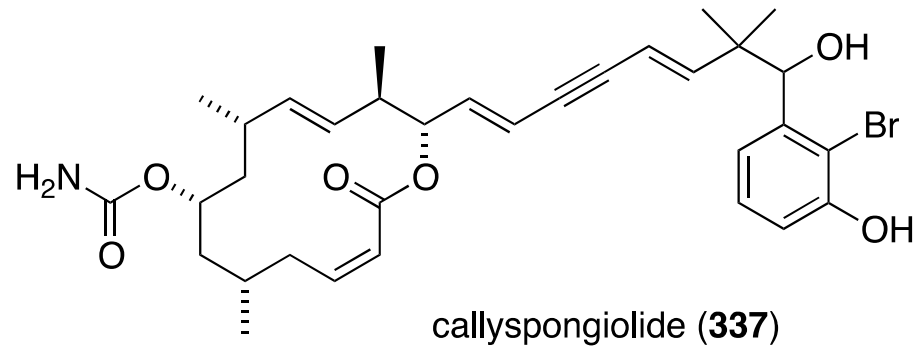

Figure 64. Structure of callyspongiolide (337) from the sponge Callyspongia sp. [131].

From a sponge of the Petrosiidae family were isolated two new macrolides, phormidolides B (338) and C (339) (Figure 65) [132], which are structurally related to the known phormidolide A and oscillariolide. The new macrolides display growth inhibition of these human cancer cell lines: A-549 (lung), HT-29 (colon), and MDA-MB-231 (breast) with IC50 values for 338/339 of 1.4/1.3, 1.3/0.8, and $1.0 / 0.5 \mu \mathrm{M}$, respectively.

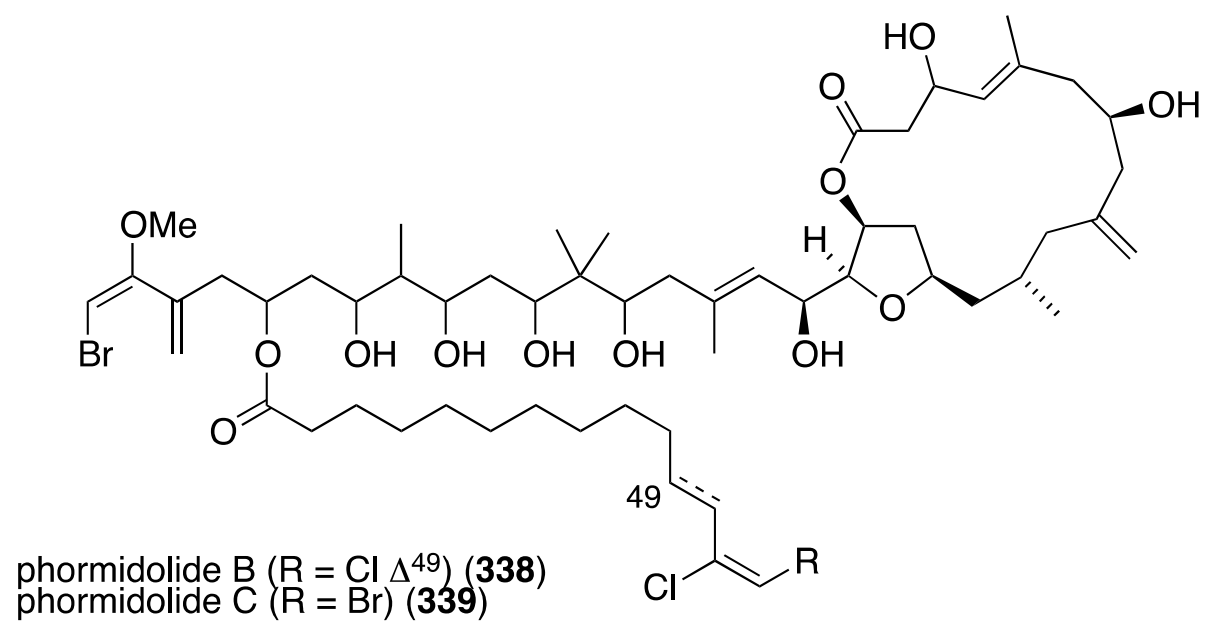

Figure 65. Structures of phormidolides B (338) and C (339) from a sponge of the Petrosiidae family [132].

The Bahamas sponge Spirastrella mollis contains mollenyne (340) (Figure 66), a highly cytotoxic chlorodibromohydrin towards HCT-116 (human colon cancer cells) with IC50 $1.3 \mu \mathrm{g} / \mathrm{mL}$ [133]. The positive control etoposide has IC50 $0.55 \mu \mathrm{g} / \mathrm{mL}$.

A collection of the sponge Theonella swinhoei from Japanese waters (Tanegashima, Kagoshima Prefecture) has provided bromotheoynic acid (341) (Figure 67) [134]. This new brominated $\mathrm{C}_{17}$ acetylenic acid inhibits the cell proliferation of U937 and HL60 (human leukemia), A549 and H1299 (human lung), and HEK293 (human embryonic kidney) with values of $\mathrm{IC}_{50} 24,27,58,72$, and $40 \mathrm{mg} / \mathrm{mL}$, 
respectively. Bromotheoynic acid also inhibits the maturation of starfish (Asterina pectinifera) oocytes at a concentration of $100 \mathrm{ng} / \mathrm{mL}$.<smiles>C#CCCC#CC=CC#CC[C@@H](Cl)[C@H](Br)[C@H](O)/C(Br)=C\CCCC(=O)NCCCCCNC(=N)N</smiles>

Figure 66. Structure of mollenyne (340) from the sponge Spirastrella mollis [133].<smiles>C#C/C=C\CCCC/C=C(\Br)CCC#CCCC(=O)O</smiles>

bromotheoynic acid (341)

Figure 67. Structure of bromotheoynic acid (341) from the sponge Theonella swinhoei [134].

The sponge Stylissa sp. from the Derawan Islands in Indonesia has yielded four new brominated alkaloids, 342-345 (Figure 68), along with eight known analogues, including 346-353 [135]. All compounds were screened for their cytotoxicity towards mouse lymphoma cells L5187Y (Table 11), but only 342, 348, 350, and 351 show strong activity in this screen. The presence of an $N$-methyl and a carbonyl group in the imidazole ring increases activity ( $\mathbf{3 4 2} v s$. 346; and 350/351), and the presence or absence of bromine may not always have a positive influence on the activity ( 346 vs. $\mathbf{3 4 7}$ ).<smiles>[R]c1[nH]c2c(c1Br)C(c1c[nH]c(=[NH2+])n1[R])=CCNC2=O</smiles>

$342\left(R^{1}=\mathrm{Me}, \mathrm{R}^{2}=\mathrm{Br}\right)$

$343\left(R^{1}=M e, R^{2}=H\right)$

$346\left(R^{1}=H, R^{2}=B r\right)$ (stevensine)

$347\left(R^{1}=R^{2}=H\right)$<smiles>[R]c1nc(N)nc2c1-c1c([nH]c(Br)c1[R])C(=O)NC2</smiles>

$$
\begin{aligned}
& 344\left(R^{1}=\mathrm{CO}_{2} \mathrm{Me}, R^{2}=\mathrm{H}\right) \\
& \mathbf{3 4 5}\left(\mathrm{R}^{1}=\mathrm{R}^{2}=\mathrm{H}\right) \\
& \left.\mathbf{3 4 8}\left(\mathrm{R}^{1}=\mathrm{H}, \mathrm{R}^{2}=\mathrm{Br}\right) \text { (latonduine } \mathrm{A}\right) \\
& \mathbf{3 4 9}\left(\mathrm{R}^{1}=\mathrm{CO}_{2} \mathrm{Me}, \mathrm{R}^{2}=\mathrm{Br}\right)
\end{aligned}
$$<smiles>[R]c1cc2c([nH]1)C(=O)NCCC2=C1NC(=[NH2+])NC1=O</smiles>

$350(\mathrm{R}=\mathrm{Br})(Z$-hymenialdisine $)$ $351(\mathrm{R}=\mathrm{H})$<smiles>O=C1CCNC(=O)c2c(Br)c[nH]c21</smiles>

352<smiles>NC(=O)c1cc(Br)c(Br)[nH]1</smiles>

353

Figure 68. Structures of brominated alkaloids 342-353 from the sponge Stylissa sp. [135]. 
Table 11. Cytotoxicity of brominated alkaloids 342-353 against mouse lymphoma cells L5187Y [135].

\begin{tabular}{ccc}
\hline Alkaloid & L5178Y\% of Inhibition Concentration $(\mathbf{1 0} \boldsymbol{\mu g} / \mathbf{m L})$ & EC $_{\mathbf{5 0}}$ \\
\hline $\mathbf{3 4 2}$ & 86.1 & 3.5 \\
$\mathbf{3 4 3}$ & 8.1 & - \\
$\mathbf{3 4 4}$ & 10.2 & - \\
$\mathbf{3 4 5}$ & 6.6 & - \\
$\mathbf{3 4 6}$ & 7.5 & - \\
$\mathbf{3 4 7}$ & 15.1 & - \\
$\mathbf{3 4 8}$ & 89.3 & 9.0 \\
$\mathbf{3 4 9}$ & 1.7 & - \\
$\mathbf{3 5 0}$ & 99.6 & 1.8 \\
$\mathbf{3 5 1}$ & 101.0 & 2.1 \\
$\mathbf{3 5 2}$ & 9.0 & - \\
$\mathbf{3 5 3}$ & 33.8 & - \\
Kahalalide F (control) & - & 6.3 \\
\hline
\end{tabular}

An examination of the Thai sponge Smenospongia sp. gathered in the Andaman Sea has uncovered the novel 6'-iodoaureol (354) and the bromoindoles 355-359 (Figure 69), isolated from a natural source for the first time, along with several other known natural products [136]. The new compounds, 354-359, and the known 360-362 were screened against a battery of human cell lines for cytotoxicity (Table 12). Only 5,6-dibromotryptamine (362) shows good activity against MOLT-3 (human leukemia) and HeLa cells, with non-halogenated aureol (360) and 355 showing some modest cytotoxicity against HL-60 and HeLa, respectively.<smiles>[R2]c1c(O)ccc(O[C@@]23CCCC(C)(C)[C@@H]2CC[C@@H](C)C3(C)C)c1C</smiles>

6'-iodoaureol $\left(R^{1}=H, R^{2}=I\right)(354)$ aureol $\left(R^{1}=R^{2}=H\right)(360)$<smiles>[R]C(=O)c1c[nH]c2cc([R])c([R])cc12</smiles>

$355\left(R^{1}=R^{2}=B r, R^{3}=O M e\right.$ $356\left(R^{1}=B r, R^{2}=H, R^{3}=O M e\right.$ $357\left(R^{1}=B r, R^{2}=R^{3}=H\right.$ $358\left(R^{1}=R^{2}=B r, R^{3}=H\right.$ $359\left(\mathrm{R}^{1}=\mathrm{Br}, \mathrm{R}^{2}=\mathrm{H}, \mathrm{R}^{3}=\mathrm{OH}\right.$ $361\left(R^{1}=R^{2}=H, R^{3}=O H\right.$<smiles>NCCc1c[nH]c2cc(Br)c(Br)cc12</smiles>

362

Figure 69. Structures of 6'-iodoaureol (354), aureol (360), and indoles 355-362 from the sponge Smenospongia sp. [136]. 
Table 12. Cytotoxicity of 354-362 against human cancer cells (IC50 $\mu \mathrm{M})$ [136].

\begin{tabular}{cccccccc}
\hline Compound & MOLT-3 & HepG2 & A549 & HuCCA-1 & HeLa & HL-60 & MDA-MB-231 \\
\hline $\mathbf{3 5 4}$ & 39.8 & 44.7 & 68.2 & 63.6 & 61.4 & 43.2 & 44.7 \\
$\mathbf{3 5 5}$ & $>100$ & 36.1 & $>100$ & $>100$ & 13.0 & $>100$ & $>100$ \\
$\mathbf{3 5 7}$ & $>100$ & $>100$ & $>100$ & $>100$ & $>100$ & $>100$ & $>100$ \\
$\mathbf{3 5 8}$ & $>100$ & $>100$ & $>100$ & $>100$ & 69.3 & - & $>100$ \\
$\mathbf{3 5 9}$ & $>100$ & $>100$ & $>100$ & $>100$ & 69.3 & - & $>100$ \\
$\mathbf{3 6 0}$ & 24.8 & 29.2 & 76.4 & 87.6 & 62.1 & 14.6 & 29.7 \\
$\mathbf{3 6 1}$ & 73.2 & $>100$ & $>100$ & $>100$ & 7.81 & 64.3 & $>100$ \\
$\mathbf{3 6 2}$ & 5.4 & 23.1 & 78.6 & 23.6 & 9.4 & - & 34.1 \\
Etoposide & 0.03 & - & - & - & - & 1.18 & - \\
Doxorubicin & - & 0.69 & 0.43 & 0.69 & 0.38 & - & 0.62 \\
\hline
\end{tabular}

Two studies of the chemical content of the Caribbean sponge Smenospongia aurea, collected in the Bahamas along the coast of Little Inagua, has led to the chlorinated smenamides A (363) and B (364), and smenothiazoles A (365) and B (366) (Figure 70) [137,138]. Whereas the smenamides exhibit selectivity and nanomolar cytotoxic activity towards Calu-1 (lung) cancer cells, the smenothizoles are equally active and selective against A2780 (ovarian) cancer cells.<smiles>COC1=CC(=O)N(C(=O)/C(C)=C/C(C)CC/C(=C/Cl)CCCN(C)C(C)=O)C1Cc1ccccc1</smiles>

smenamide A (363)<smiles>CC(=CCC(=CCl)Cc1ccccc1)C(=O)NC(C(=O)N1CCC[C@H]1c1nccs1)C(C)C</smiles>

smenothiazole A (365)<smiles>COC1=CC(=O)N(C(=O)/C(C)=C\C(C)CC/C(=C/Cl)CCCN(C)C(C)=O)C1Cc1ccccc1</smiles><smiles>C#CCCCC(=CCl)CC=C(C)C(=O)NC(C(=O)N1CCC[C@H]1c1nccs1)C(C)C</smiles>

smenothiazole B (366)

Figure 70. Structures of smenamides A (363) and B (364), and smenothiazoles A (365) and B (366) from the sponge Smenospongia aurea [137,138].

The first naturally occurring trimeric hemibastadin, sesquibastadin 1 (367), was characterized from the sponge Ianthella basta, found in Ambon, Indonesia (Figure 71) [139]. The known bastadins 3, 6, 7, 11 , and 16 were also isolated. Whereas sesquibastadin 1 does not display cytotoxicity against L5178Y cells (mouse lymphoma), bastadins $6,7,11$, and 16 do inhibit cell proliferation, with $\mathrm{IC}_{50}$ values of $1.5,5.3,3.7$, and $1.9 \mu \mathrm{M}$, respectively. However, sesquibastadin 1 is a potent protein kinase inhibitor as seen in a later section. 


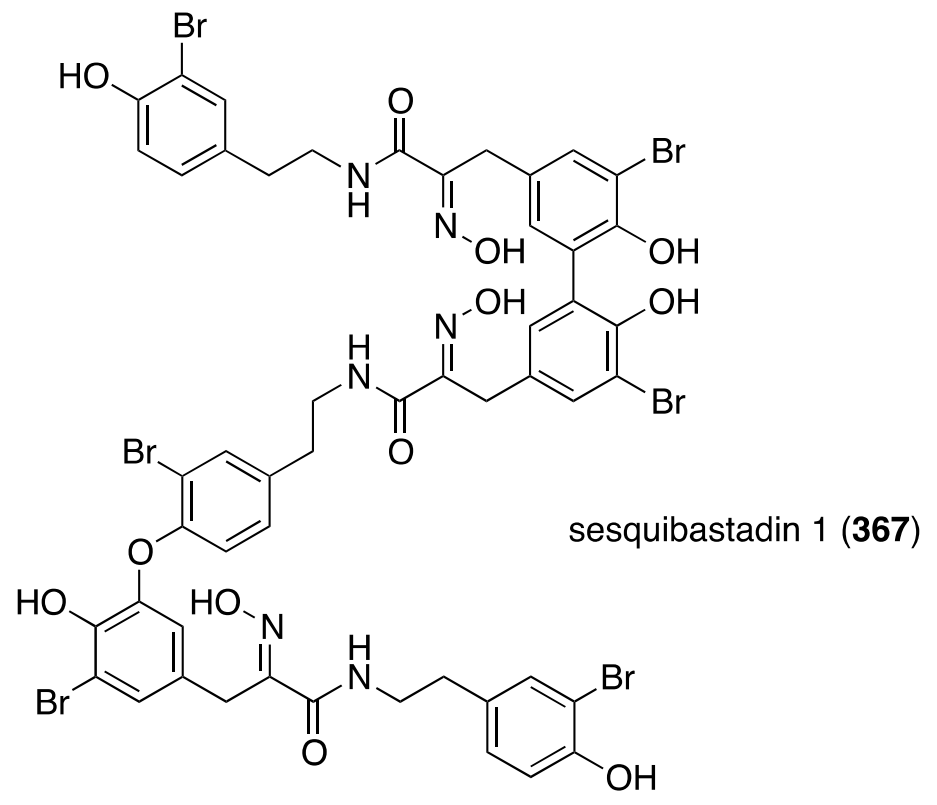

Figure 71. Structure of sesquibastadin 1 (367) from the sponge Ianthella basta [139].

The Red Sea sponge Pseudoceratina arabica from Hurghada at the Egyptian coast contains the new ceratinines A-E (368-372) (Figure 72), in addition to several known brominated alkaloids [140]. Screening of all isolated compounds against the highly metastatic MDA-MB-251 human breast cancer cell line reveals that only the known subereamolline A (373) is highly active, showing $\mathrm{IC}_{50} 1.7 \mu \mathrm{M}$.<smiles>COC(CN)c1cc(Br)c(OCCCN)c(Br)c1</smiles>

ceratinine $A(368)$<smiles>Cc1c(Br)c(OCC2OC2N)c(Br)c2c1CCCN2</smiles>

ceratinine B (369)<smiles>NCCc1cc(Br)c(OCCCNC(N)=O)c(Br)c1</smiles>

ceratinine C (370)<smiles>CCOC(=O)NCCCOc1c(Br)cc(CCNC=O)cc1Br</smiles>

ceratinine $D(\mathbf{3 7 1})$<smiles>CCOC(=O)NCCCCNC(=O)C1=NO[C@]2(C=C(Br)C(OC)=C(Br)[C@@H]2O)C1</smiles>

subereamolline A (373)

Figure 72. Structures of ceratinines A-E (368-372) and subereamolline A (373) from the sponge Pseudoceratina arabica [140]. 
An Australian version of Pseudoceratina verrucosa has furnished the new pseudoceralidinone A (374) and aplysamine 7 (375) (Figure 73), in addition to the known aerophobin 2, fiscularin 2, and fistularin 3 (not shown) [141]. Of these five bromotyrosines, only aplysamine 7 (375) shows cytotoxicity towards PC3 (prostate) cancer cells with $\mathrm{IC}_{50} 4.9 \mu \mathrm{M}$. All five compounds are inactive against HeLa (cervical) and NFF (human neonatal foreskin fibroblast) cells (IC50 $>10 \mu \mathrm{M}$ ).<smiles>CN(C)CCCOc1c(Br)cc(C2CNC(=O)O2)cc1Br</smiles>

pseudoceralidinone (374)<smiles>CNCCCOc1c(Br)cc([C@H](O)CNC(=O)/C(Cc2ccc(OC)c(Br)c2)=N/O)cc1Br</smiles>

aplysamine 7 (375)

Figure 73. Structures of pseudoceralidinone A (374) and aplysamine 7 (375) from Pseudoceratina verrucosa [141].

The South China Sea sponge Acanthella cavernosa has afforded the new cavernenes A-D (376-379), kalihinenes E (380) and F (381), and kalihipyran C (382) (Figure 74), in addition to several known analogues [142]. These metabolites were screened against several human cancer cell lines (Table 13). Cavernenes A and B display modest cytotoxicity towards HCT-116, and cavernene D shows slight activity against all five cell lines. The other new compounds $(\mathbf{3 7 8}, \mathbf{3 7 9}, \mathbf{3 8 1}, \mathbf{3 8 2})$ are inactive across the board.<smiles>C=C(CCC=C(C)C)[C@H]1CC[C@](C)(NC=O)[C@H]2CCC(C)=C[C@H]12</smiles>

cavernene $A(\mathbf{3 7 6})$

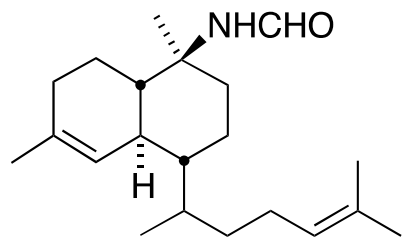

cavernene B (377)<smiles>CC(C)=CCCC(C)C1CC[C@H](N)[C@H]2CCC(C)=C[C@H]12</smiles>

cavernene $\mathrm{C}(\mathbf{3 7 8})$<smiles>CC(C)=CCC1O[C@]1(C)C1CC[C@](C)(NC=O)[C@H]2CCC(C)=C[C@H]12</smiles>

cavernene D (379)<smiles>CC1=C[C@H]2C([C@]3(C)CC[C@@H](Cl)C(C)(C)O3)CC[C@](C)(NC=O)[C@@H]2CC1</smiles>

kalihinene $E(380)$<smiles>CNC(C)(C)[C@H]1CC[C@@](C)([C@H]2CC=C(C)[C@H]3CCC(C)=C[C@@H]32)O1</smiles>

kalihinene $\mathrm{F}$ (381)<smiles>C=C(C)C1CC=C(C2CC[C@@H](NC=O)[C@H]3CCC(C)=C[C@H]23)OC1</smiles>

kalihipyran C (382)

Figure 74. Structures of cavernenes A-D (376-379), kalihinenes E (380) and F (381) and kalipyran C (382) from the sponge Acantella cavernosa [142]. 
Table 13. Cytotoxicity of $\mathbf{3 7 6}, \mathbf{3 7 7}, \mathbf{3 8 0}$, and selected known analogues against human cell lines $\left(\mathrm{IC}_{50} \mu \mathrm{M}\right)$ [142].

\begin{tabular}{lccccc}
\hline \multicolumn{1}{c}{ Compound } & HCT-116 & A549 & HeLa & QGY-7701 & MDA-MB-231 \\
\hline $\mathbf{3 7 6}$ & 6.31 & $>50$ & $>50$ & $>50$ & $>50$ \\
$\mathbf{3 7 7}$ & 8.99 & $>50$ & $>50$ & $>50$ & $>50$ \\
$\mathbf{3 8 0}$ & 14.36 & $>50$ & 13.36 & 17.78 & 12.84 \\
kalihipyran A & $>50$ & 13.09 & 11.19 & 13.53 & $>50$ \\
15-formamido-kalihinene & $>50$ & 17.53 & 14.74 & 16.39 & $>50$ \\
10-formamido-kalihinene & $>50$ & 6.98 & 13.30 & 14.53 & 6.84 \\
kalihinene X & 12.25 & 8.55 & 10.59 & 13.02 & 7.46 \\
kalihinene Y & $>50$ & 17.12 & 10.05 & 14.41 & 15.23 \\
camptothecin & 9.25 & 2.32 & 6.98 & 4.05 & 0.50 \\
\hline
\end{tabular}

A number of known marine organohalogens were examined for possible cytotoxicity against cancer cell lines during the period covered by this review. To conserve space, their structures are not shown. A review of the antitumor activity of the Jaspis sponges is available [143]. The Fascaplysinopsis sp. sponge metabolite fascaplysin displays excellent cytotoxicity against chemoresistant SCLC (small cell lung cancer) cell lines, by multiple mechanisms [144]. Other cell lines are also discussed. The Suberea sp. sponge alkaloids ma'edamines A and B display significant cytotoxicity against COLO 205 (human colon cancer), MCF-7 (human breast cancer), and A549 (human lung) with $\mathrm{IC}_{50}$ values of 7.9/10.3, 6.9/10.5, and 12.2/15.4 for ma'edamines A/B, respectively [145]. Synthetic analogues show activity against three breast cancer cell lines representing hormone receptor positive and HER2 positive breast cancer [146]. The bis-indole alkaloid 6"-debromohamacanthin A from a Spongosorites sp. sponge inhibits angiogenesis in human umbilical vascular endothelial cells and mouse embryonic cells [147]. The Pseudoceratina sp. alkaloids ceratamines A and B disrupt microtubule dynamics, which provides an explanation for their pronounced antimitotic activity (lower micromolar) [148]. The well known dibromo-dihydroxyoxocyclohexenyl acetonitrile has excellent activity against the K562 leukemia cell line ( $\mathrm{IC}_{50} 1.4 \mu \mathrm{g} / \mathrm{mL}$ ) [149]. The known spirastrellolides A and B were isolated from the sponge Epipolasis sp. for the first time as free acids, and not as methyl esters. Both macrolides are cytotoxic to HeLa cells, with $\mathrm{IC}_{50} 20$ and $40 \mathrm{nM}$, respectively [150].

The previously cited dictyodendrins F-I (74-77) (Figure 14) are cytotoxic towards the SW620 (human colon) cancer cell line with $\mathrm{IC}_{50}$ values of $8.5,2.0,16$, and $10 \mu \mathrm{M}$, respectively. Dictyodendrin $\mathrm{J}$ is not cytotoxic. None of the five compounds is cytotoxic towards the multi-drug resistant variant SW620 Ad300 [49]. The kalihinols M-T (100-107) (Figure 18) were screened against several human cancer cell lines, along with some previously known kalihinols, and show weak to modest cytotoxicity (Table 14) [55].

The aforementioned new hamigerans F-J (204-208) (Figure 36) all show some degree of cytotoxicity towards HL-60 (human promyelocytic leukemia) with F (204), G (205), and 209 showing IC 50 values of $4.9,2.5$, and $5.6 \mu \mathrm{M}$, respectively. The known hamigeran B is $3.4 \mu \mathrm{M}$ [83]. The two most active hamigerans, $\mathrm{G}$ and $\mathrm{B}$, share the same electrophilic 1,2-dione functionality. Of the three psammaplysins 252-254 (Figure 45), psammaplysin F (254) is moderately cytotoxic against the HepG2 human carcinoma cell line ( $\mathrm{IC}_{50} 3.7 \mu \mathrm{M}$ ). Psammaplysins $\mathrm{G}$ (253) and H (252) show IC50 values of 17.4 and $>40 \mu \mathrm{M}$, respectively [104]. 
Table 14. Cytotoxicity of kalihinols M-T (100-107) and related kalihinols against human cancer cell lines $\left(\mathrm{IC}_{50} \mu \mathrm{M}\right)$ [55].

\begin{tabular}{lccc}
\hline \multicolumn{1}{c}{ Kalihinol } & HCT-116 & H1299 & CT-26 \\
\hline kalihinol O (102) & 5.97 & - & - \\
kalihinol P (103) & 10.68 & 26.21 & - \\
kalihinol Q (104) & 20.55 & - & - \\
kalihinol R (105) & 13.44 & - & - \\
kalihinol E & 18.31 & - & - \\
kalihinol A & 17.40 & - & - \\
10-epi-kalihinol X & 8.21 & - & - \\
10-epi-kalihinol I & 28.67 & - & - \\
10- $\beta$-formamidokalihinol-A & - & - & 28.82 \\
\hline
\end{tabular}

Red marine algae are also an excellent source of novel antitumor compounds with genus Laurencia in the limelight. A collection of Laurencia similis from the South China Sea has yielded the novel enantiomeric spiro-trisindoles similisines A (383) and B (383b), along with the new oxindole 384 (Figure 75) [151]. The racemate $\mathbf{3 8 3}$ was separated into similisines A and B by enantioselective HPLC. All three compounds were screened against eight human cancer cell lines but only oxindole $\mathbf{3 8 4}$ shows (weak) activity against HL-60 (leukemia) and JURKA (leukemia) with values of IC50 35.06 and $53.27 \mu \mathrm{M}$, respectively.<smiles></smiles>

similisine A (383a)<smiles>C[C@H]1c2c([nH]c3cc(Br)c(Br)cc23)[C@@H](c2c(Br)[nH]c3cc(Br)c(Br)cc23)[C@@]12C(=O)Nc1cc(Br)c(Br)cc12</smiles>

similisine B (383b)<smiles>CN1C(=O)Cc2ccc(Br)cc21</smiles>

384

Figure 75. Structures of similisines A (383a) and B (383b), and oxindole 384 from Laurencia similis [151].

An extensive examination of Laurencia viridis from the Canary Islands led to seven new brominated polyether triterpenoids, 15-dehydroxythyrsenol A (385), prethyrsenol A (386), 13-hydroxyprethyrsenol A (387) [152], iubol (388), 22-hydroxy-15(28)-dehydrovenustatriol (389) [153], and saiyacenols A (390) and B (391) [154] (Figure 76), along with two new non-brominated analogues 1,2-dehydropseudodehydrothyrsiferol and secodehydrothyrsiferol (not shown) [153]. These new oxasqualenoids were screened against several human cancer cell lines (Table 15). Jurkat cells are clearly the most sensitive to these brominated polyethers. The non-brominated secodehydrothyrsiferol shows $\mathrm{IC}_{50} 2.5 \mu \mathrm{M}$ in this assay. 
<smiles>CC1(C)OC(C)([C@H]2CC[C@@]3(C)OC(C(CO)CC[C@H](O)[C@]4(C)CC[C@H](C(C)(C)O)O4)=CC[C@@H]3O2)CCC1Br</smiles><smiles>CCCCCCCCCCCCCCCC(=O)C(O)(CO)CC[C@@H](O)[C@]1(C)CC[C@@H](C(C)(C)O)O1</smiles><smiles>CC(C)(O)[C@H]1CC[C@@](C)(O)[C@@H](C[C@@H](O)CC(=O)[C@@](O)(CO)CCC(O)[C@]2(C)CC[C@@H](Br)C(C)(C)O2)O1</smiles>

13-hydroxyprethyrsenol A (387)<smiles>C=C(CC[C@H](O)[C@]1(C)CC[C@@H](O)C(C)(C)O1)C1CC[C@@H]2O[C@H](C3(C)CCC(Br)C(C)(C)O3)CC[C@]2(C)O1</smiles><smiles>C=C(CC[C@@H](O)C1(C)CCC(O)(C(C)(C)O)O1)C1CC[C@@H]2O[C@H](C3(C)CCC(Br)C(C)(C)O3)CC[C@]2(C)O1</smiles>

22-hydroxy-15(28)-dehydrovenustatriol (389)

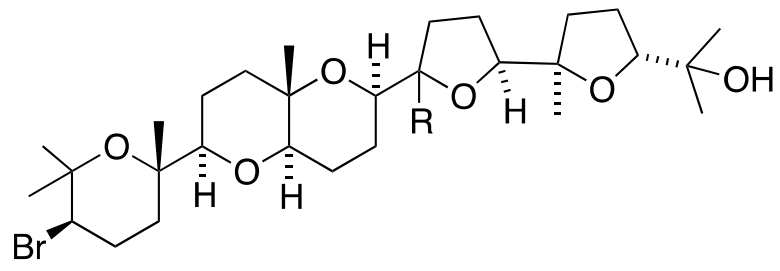

saiyacenol $A(R=\beta-M e)(390)$

saiyacenol $B(R=\alpha-M e)(391)$

Figure 76. Structures of polycyclic triterpenoids 385-391 from Laurencia viridis [152-154].

Table 15. Cytotoxicity of polycyclic triterpenoids 385-391 against human cancer cell lines (IC50 $\mu \mathrm{M})$ [152-154].

\begin{tabular}{ccccc}
\hline Compound & Jurkat $^{\mathbf{a}}$ & MM144 $^{\mathbf{b}}$ & HeLa $^{\mathbf{c}}$ & CAD-ES-1 \\
\hline $\mathbf{3 8 5}$ & 7.6 & 7.3 & 23.0 & 16.5 \\
$\mathbf{3 8 6}$ & 8.2 & 10.2 & 29.0 & 14.5 \\
$\mathbf{3 8 7}$ & 7.2 & 15.5 & 26.0 & 3.1 \\
$\mathbf{3 8 8}$ & 3.5 & 13.0 & 27.0 & 11.0 \\
$\mathbf{3 8 9}$ & 2.0 & - & 2.9 & - \\
$\mathbf{3 9 0}$ & 7.8 & 27.0 & 27.5 & 25.5 \\
$\mathbf{3 9 1}$ & 2.7 & 11.0 & 24.5 & 14.0 \\
\hline
\end{tabular}

${ }^{\mathrm{a}}$ T-cell acute leukemia; ${ }^{\mathrm{b}}$ multiple myeloma; ${ }^{\mathrm{c}}$ cervical carcinoma; ${ }^{\mathrm{d}}$ Ewing's sarcoma.

The polybromoindoles from Laurencia brongniarii (Figure 21) were tested for cytotoxicity, but in this group only 2,4,5,6-tetrabromo-3-methylthioindole shows activity against Hep3B (liver carcinoma) and MCF-7 (breast carcinoma); IC50 7.7 and $10.5 \mu \mathrm{M}$, respectively. For comparison, the non-halogenated doxorubicin has values of $\mathrm{IC}_{50} 1.2$ and $1.5 \mu \mathrm{M}$, respectively. Other cell lines examined were HepG2, MDA-MB-231, and A549 [62]. Of the six new laurane-type sesquiterpenes from Laurencia okamurai

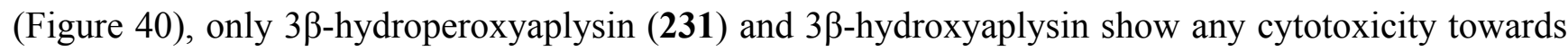
the A-549 cell line (IC50 35.3 and $15.4 \mu \mathrm{M}$, respectively. All other compounds are $\mathrm{IC}_{50}>100 \mu \mathrm{M}$ [89]. The known bis-(2,3-dibromo-4,5-dihydroxyphenyl)methane from Laurencia nana and Rhodomela confervoides displays significant growth inhibition against some cell lines (IC50 $\mu \mathrm{g} / \mathrm{mL}$ ): HeLa (17.6), 
RKO (colon; 11.4), HCT-116 (colon; 10.6), BEL-7402 (hepatoma; 8.7), U87 (glioblastoma; 23.7), and HUVEC (vascular endothelial; 30.2). Moreover, this compound induces detachment of the cancer cells and apoptosis, and inhibits metastasis [155]. Although the Asparagopsis taxiformis cyclopentenones mahorone (108) and 5-bromomahorone (109) (Figure 19) are not cytotoxic towards several human cancer cell lines (A549, HepG2, HT29, and MCF7), mahorone is cytotoxic against healthy liver cells (54\% growth inhibition at $5 \mu \mathrm{M}$ ) [58]. The bromoditerpene from Sphaerococcus coronopifolius, sphaerodactylomelol (122) (Figure 21), shows some cytotoxicity and anti-proliferative property against HepG-2 cells (IC50 720 and $280 \mu \mathrm{M}$, respectively). The known sphaerococcenol shows IC50 $43 \mu \mathrm{M}$ for anti-proliferative activity. For comparison, cisplatin and tamoxifen have $\mathrm{IC}_{50}$ values of 75 and $46 \mu \mathrm{M}$, respectively [63]. In contrast, bromophycoic acid E (131) from Callophycus sp. (Figure 22) shows cytotoxicity of $\mathrm{IC}_{50} 6.8 \mu \mathrm{M}$ as the mean value of 14 human cancer cell lines. The other bromophycoic acids are less active [64]. The South African Plocamium suhrii has provided the new halogenated monoterpenes 392 and 393 (Figure 77) and the known 394-398 [156]. These compounds were screened against the human esophageal cancer cell line WHCO1 with the following $\mathrm{IC}_{50}$ values $(\mu \mathrm{M})$ : 392 (9.3), 393 (7.9), 394 (6.6), 395 (9.9), 396 (8.5), 397 (8.4), and 398 (15.1). For comparison, cisplatin has $\mathrm{IC}_{50} 13 \mu \mathrm{M}$. Tetrachloro monoterpene 393 was previously isolated from Plocamium corallorhiza but not fully characterized [156].<smiles>[R]C([R])=C[C@@](C)(Cl)[C@@H](Cl)/C=C/C(=C\Cl)C(Cl)Cl</smiles>

$392\left(\mathrm{R}^{1}=\mathrm{Br}, \mathrm{R}^{2}=\mathrm{H} ; 4 R\right)$

$394\left(\mathrm{R}^{1}=\mathrm{H}, \mathrm{R}^{2}=\mathrm{Br} ; 4 \mathrm{~S}\right)$

$395\left(\mathrm{R}^{1}=\mathrm{H}, \mathrm{R}^{2}=\mathrm{Br} ; 4 R\right)$

$396\left(R^{1}=R^{2}=H ; 4 S\right)$<smiles>C=C[C@](C)(Cl)C(Cl)CC(Cl)C(C)(C)Cl</smiles>

393<smiles>C/C(C=C[C@@H](Cl)[C@@](C)(Cl)/C=C/Br)=C/Br</smiles>

$397(4 R)$

$398(4 S)$

Figure 77. Structures of halogenated monoterpenes from Plocamium suhrii [156].

The Synoicum sp. eudistomins $\mathrm{Y}_{2}-\mathrm{Y}_{7}$ (132-137) (Figure 23) were screened against A549 cancer cells, but only the previously known eudistomin $\mathrm{Y}_{9}$ shows cytotoxicity (IC $\mathrm{I}_{50} 17.9 \mu \mathrm{M}$ ) (doxorubicin has $\mathrm{LC}_{50} 3.3 \mu \mathrm{M}$ ) [65]. Another known Synoicum sp. ascidian metabolite, prunolide A, is cytotoxic to breast cancer cell lines at $<1 \mu \mathrm{M}$ [122]. The newest member of the synoxazolidinone family of metabolites from Synoicum pulmonaria is synoxazolidinone C (399) (Figure 78), which is cytotoxic to several human cancer cell lines: A2058 (melanoma), MCF-7 (breast), and HT-29 (colon) at IC $5030.5 \mu \mathrm{M}$. This compound also kills normal lung fibroblast cells (MRC-5) at the same concentration [157].<smiles>COc1c(Br)cc(/C=C2\O[C@@H]3[C@H](Cl)C[C@@H](NC(=N)N)N3C2=O)cc1Br</smiles>

synoxazolidinone C (399)

Figure 78. Structure of synoxazolidinone (399) from the ascidian Synoicum pulmonaria [157]. 
The tunicate Diazona cf formosa living off the coast of Timor Island, near Indonesia, has afforded the novel tanjungides A (400) and non-halogenated B (401) (Figure 79) [158]. Cytotoxicity of these bromoindoles was assayed against A549, HT29, and MDA-MB-231 human cancer cell lines. The data show that tanjungide $\mathrm{A}(\mathbf{4 0 0})$ is strongly active against the three cell lines: $\mathrm{IC}_{50} 0.33,0.19$, and $0.23 \mu \mathrm{M}$, respectively. Tanjungide $\mathrm{B}$ is much less active ( $\mathrm{IC}_{50} 2.50,2.31$, and $1.63 \mu \mathrm{M}$, respectively).<smiles>N[C@@H]1CSSC[C@@H](C(=O)N/C=C\c2c[nH]c3cc(Br)c(Br)cc23)NC1=O</smiles>

tanjungide $A(400)$<smiles>NC1CSSCC(C(=O)N/C=C/c2c[nH]c3ccccc23)NC1=O</smiles>

tanjungide $B(401)$

Figure 79. Structures of tanjungides A (400) and B (401) from the tunicate Diazona cf formosa [158].

The two new chlorinated didemnins $\mathbf{4 0 2}$ and $\mathbf{4 0 3}$ were isolated from the tunicate Trididemnum solidum from Little Cayman island along with the known nonchlorinated didemnins A (404) and B (405) (Figure 80) [159]. All four didemnins were evaluated for cytotoxicity against human cancer cells (Table 16), and all strongly inhibit cell proliferation in the cancer cell lines, especially didemnuns A and $\mathrm{B}$, but not in the noncancerous VERO cell line.

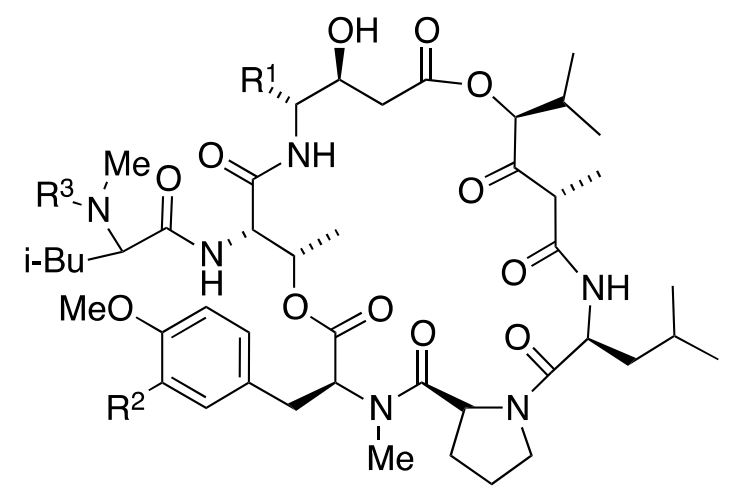

$402\left(\mathrm{R}^{1}=i-\mathrm{Bu}, \mathrm{R}^{2}=\mathrm{Cl}, \mathrm{R}^{3}=\mathrm{H}\right)$ $403\left(\mathrm{R}^{1}=i-\mathrm{Pr}, \mathrm{R}^{2}=\mathrm{Cl}, \mathrm{R}^{3}=\mathrm{H}\right)$ didemnin $\mathrm{A}\left(\mathrm{R}^{1}=i-\mathrm{Bu}, \mathrm{R}^{2}=\mathrm{R}^{3}=\mathrm{H}\right)(\mathbf{4 0 4})$ didemnin $B\left(\mathrm{R}^{1}=i\right.$-Bu, $\mathrm{R}^{2}=\mathrm{H}, \mathrm{R}^{3}=$ Pro-Lac) (405)

Figure 80. Structures of didemnins 402-405 from the tunicate Trididemnum solidum [159].

Table 16. Anti-cell proliferative activity of didemins 402-405 ( $\left.\mathrm{IC}_{50} \mu \mathrm{M}\right)$ [159].

\begin{tabular}{cccccc}
\hline Didemnin & SK-MEL $^{\mathbf{a}}$ & KB $^{\mathbf{b}}$ & BT-549 $^{\mathbf{c}}$ & SK-OV-3 $^{\mathbf{d}}$ & VERO $^{\mathbf{e}}$ \\
\hline $\mathbf{4 0 2}$ & 0.12 & 0.26 & 0.16 & 0.26 & 4.8 \\
$\mathbf{4 0 3}$ & 0.06 & 0.42 & 0.16 & 0.38 & 2.08 \\
$\mathbf{4 0 4}$ & 0.055 & 0.16 & 0.07 & 0.16 & 4.78 \\
$\mathbf{4 0 5}$ & 0.022 & 0.09 & 0.02 & 0.1 & 0.15 \\
Doxorubicin & 1.1 & 1.66 & 1.01 & 1.66 & 14 \\
\hline
\end{tabular}

${ }^{\mathrm{a}}$ Melanoma; ${ }^{\mathrm{b}}$ epidermal carcinoma; ${ }^{\mathrm{c}}$ breast; ${ }^{\mathrm{d}}$ ovarian; ${ }^{\mathrm{e}}$ monkey kidney fibroblasts. 
The Formosan soft coral Klyxum molle has afforded 11 new eunicellin-type diterpenoids, klymollins I-S (406-416) four of which, I-L, contain chlorine (Figure 81) [160]. Of the klymollins screened for cytotoxicity against the human cancer cell lines K562 myeloblastoid (leukemia), Molt-4 (lymphoblastic leukemia), and T47D (breast carcinoma) only klymollin M (410) shows activity: ED50 $7.97,4.35$, and $8.58 \mu \mathrm{M}$, respectively.

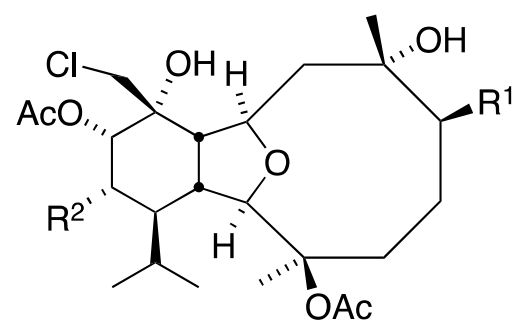

klymollin I $\left(R^{1}=R^{2}=\right.$ OAc) $(406)$

klymollin $J\left(R^{1}=\mathrm{OH}, \mathrm{R}^{2}=\mathrm{OAc}\right)(407)$

klymollin $K\left(R^{1}=O A c, R^{2}=H\right)(408)$

klymollin $L\left(R^{1}=O H, R^{2}=H\right)(409)$

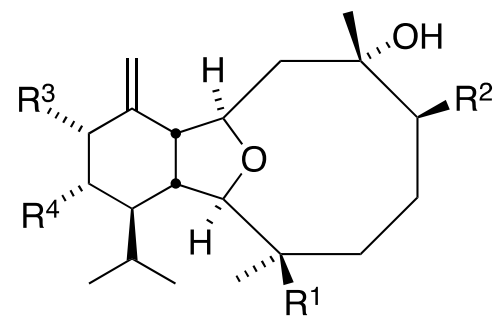

klymollin $\mathrm{N}\left(\mathrm{R}^{1}=n-\mathrm{PrCO}_{2}, \mathrm{R}^{2}=\mathrm{R}^{4}=\mathrm{OAc}, \mathrm{R}^{3}=\mathrm{OH}\right)(411)$

klymollin $\mathrm{O}\left(\mathrm{R}^{1}=n-\mathrm{PrCO}_{2}, \mathrm{R}^{2}=\mathrm{R}^{3}=\mathrm{OAc}, \mathrm{R}^{4}=\mathrm{OH}\right)(\mathbf{4 1 2})$

klymollin $\mathrm{P}\left(\mathrm{R}^{1}=n-\mathrm{PrCO}_{2}, \mathrm{R}^{2}=\mathrm{R}^{3}=\mathrm{OH}, \mathrm{R}^{4}=\mathrm{OAc}\right)(\mathbf{4 1 3})$

klymollin $Q\left(R^{1}=R^{2}=O A c, R^{3}=O H, R^{4}=H\right)(414)$

klymollin $R\left(R^{1}=\mathrm{OAc}, \mathrm{R}^{2}=\mathrm{R}^{3}=\mathrm{OH}, \mathrm{R}^{4}=\mathrm{H}\right)(\mathbf{4 1 5})$

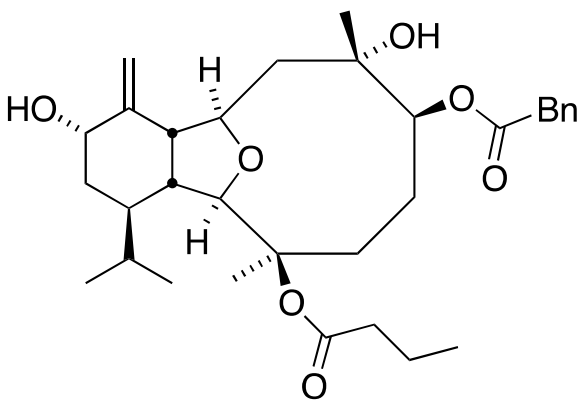

klymollin M (410)

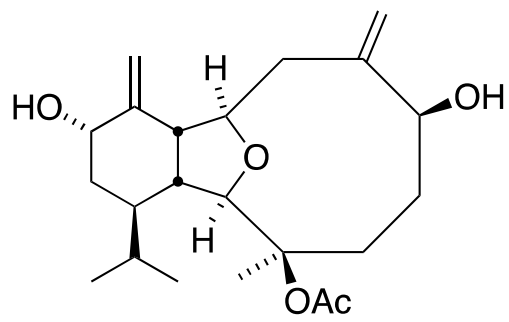

klymollin S (416)

Figure 81. Structures of klymollins I-S (406-416) from the soft coral Klyxum molle [160].

The earlier discussed gemmacolides and dichotellides from the gorgonian Dichotella gemmacea (Figures 1 and 2) display some antitumor properties [30-34,161]. Against the human cancer cell lines A549 (lung adenocarcinoma) and MG63 (osteosarcoma), gemmacolides V (9) and Y (11) show IC50 values of $<1.5$ and $<0.3 \mu \mathrm{M}$, respectively, against A549; and gemmacolide $\mathrm{Y}$ has $\mathrm{IC}_{50}<0.3 \mu \mathrm{M}$ towards MG63. The positive control adriamycin gives $\mathrm{IC}_{50} 2.8$ and $3.2 \mu \mathrm{M}$ for these two cell lines, respectively [31]. Juncin R shows 5.6 $\mu \mathrm{M}$ towards MG63 cells [30]. Of gemmacolides G-M, only gemmacolide $\mathrm{J}$ shows good growth inhibition against A549 cells $\left(\mathrm{IC}_{50}<1.4 \mu \mathrm{M}\right)$ [33]. The dichotellides F-U are not cytotoxic to the human cancer cell lines SW1990, MCF-7, HepG2, and H460 cell lines, but dichotellide C displays (marginal) activity towards SW1990 (pancreatic) with IC $\mathrm{C}_{50} 45 \mu \mathrm{M}$ (fluorouracil, $\mathrm{IC}_{50} 121 \mu \mathrm{M}$ ) [34]. A later tour de force examination of Dichotella gemmacea revealed the presence of 18 new gemmacolides AA-AR (417-434) (Figure 82) [161]. The most cytotoxic compound in the A549 and MG63 cell line assays is gemmacolide AH (424) with $\mathrm{IC}_{50}$ for both cell types (adriamycin: $\mathrm{IC}_{50} 2.8$ and $3.2 \mu \mathrm{M}$ ). 


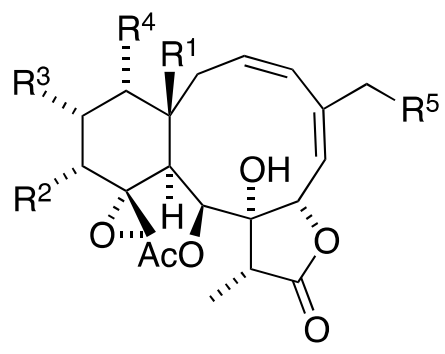

$$
\begin{aligned}
& \mathrm{X}=\mathrm{OCOCH}_{2} \mathrm{OCOCH}_{2} \mathrm{CHMe}_{2} \\
& \mathrm{Y}=\mathrm{OCOCH}_{2} \mathrm{OH} \\
& \mathrm{Z}=\mathrm{OCOCH}_{2} \mathrm{CHMe}_{2}
\end{aligned}
$$

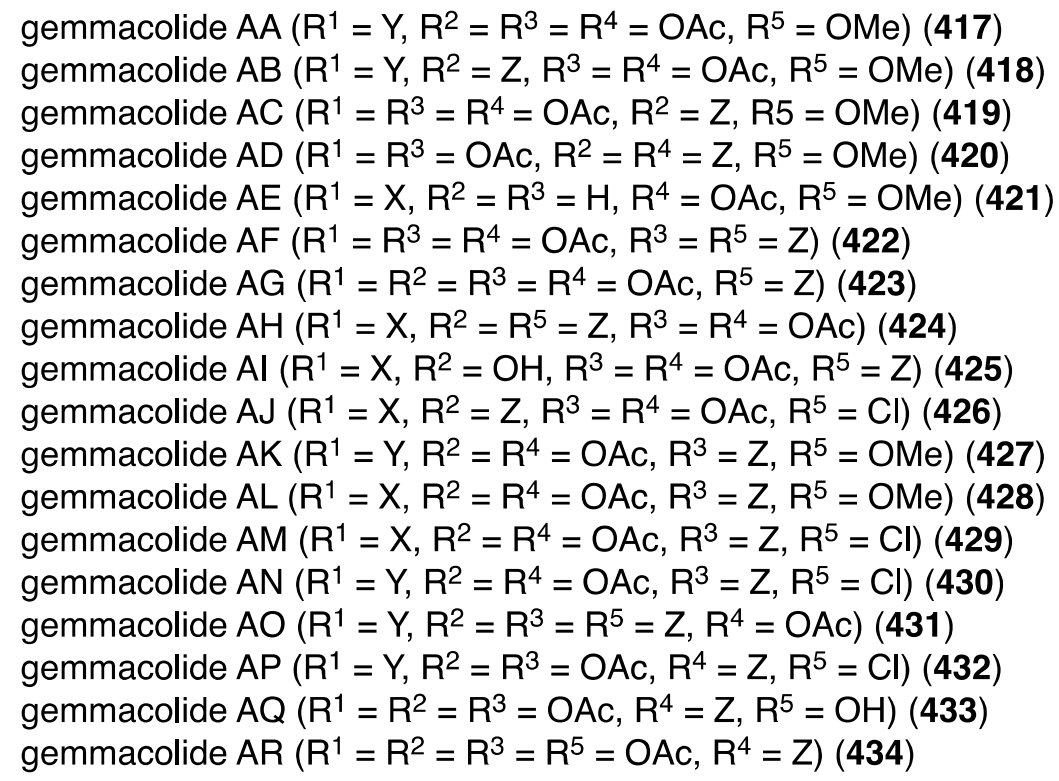

Figure 82. Structures of gemmacolides AA-AR (417-434) from the gorgonian Dichotella gemmacea [161].

A study of the cochliomycins A-C (39-41) (Figure 5) reveals no cytotoxicity against A549 and HepG2 cancer cells, but the related LL-Z1640-1 shows modest activity; IC 5044.5 and $98.6 \mu \mathrm{M}$, respectively [37]. The structurally related resorcylic acid lactones, greensporones $\mathbf{4 3 5}-\mathbf{4 4 8}$ (Figure 83) from the aquatic fungus Halenospora sp., were assayed for antitumor activity [162]. However, only greensporone $\mathrm{C}$ (439) shows significant cytotoxicity against the cell lines MDA-MB-435 (melanoma) and HT-29 (colon) with IC 502.9 and $7.5 \mu \mathrm{M}$, respectively.

The sponge-derived fungus Stachybotry sp. HH1 ZDDS1F1-2 has yielded several sesquiterpenoids and xanthones, totaling 15 compounds. In addition to the two new xanthones, stachybogrisephenones A (449) and B (450), the three known compounds grisephenone A (451), 452, and 453 are cytotoxic towards U937, HeLa, and K562 cell lines (Figure 84) [163]. Grisephenone A (451) has IC50 22.5 and 14.6 $\mu \mathrm{M}$ towards U937 and HeLa cells, respectively. Compound 452 has IC50 22.3 and $14.0 \mu \mathrm{M}$ against K562 and HeLa, respectively, and $\mathbf{4 5 3}$ shows $\mathrm{IC}_{50} 7.2 \mu \mathrm{M}$ against the HeLa cell line.

In addition to the new griseofulvins 454 and 455, the mangrove-derived (Pongamia pinnata) fungus Nigrospora sp. MA75 has afforded the quinone 456, along with several known compounds (griseofulvins, xanthones, benzophenones) (Figure 85) [164]. Non-halogenated compound 456 is cytotoxic to these human cancer cell lines: MCF-7 (breast), SW1990 (pancreas), HepG2 (hepatocellular liver), NCI-H460 (lung), DU145 (prostate), and SMMC7721 (hepatocellular liver) with these respective IC50 values $(\mu \mathrm{g} / \mathrm{mL}): 4,5,20,11,17$, and $7 \mu \mathrm{g} / \mathrm{mL}$. For comparison, fluorouracil shows $\mathrm{IC}_{50}$ 4, 16, 14, 1 , 0.4 , and $2 \mu \mathrm{g} / \mathrm{mL}$, respectively. 
<smiles>[R]c1cc(C(=O)OC(C)CCC(=O)CCC=CC(=O)Cc2ccccc2[2H])c(OC)cc1O</smiles>

greensporone $A(R=C l)(435)$ dechlorogreensporone $A(R=H)(438)$<smiles>[R2]c1cc(C(=O)O[C@H](C)CC[C@@H]([R9])CC/C=C/C(=O)Cc2ccccc2[R])c(O)cc1O</smiles>

greensporone $C\left(R^{1}=M e, R^{2}=R^{3}=H\right)(439)$

O-desmethylgreensporone $C\left(R^{1}=R^{2}=R^{3}=H\right)(440)$

greensporone $D\left(R^{1}=M e, R^{2}=C l, R^{3}=O H\right)(442)$

dechlorogreensporone $D\left(R^{1}=M e, R^{2}=H, R^{3}=O H\right)(444)$<smiles>COc1cc(O)c(Cl)c(CC(=O)/C=C\CC[C@H](O)CC[C@@H](C)OC(=O)c2c(OC)cc(O)c(Cl)c2CC(=O)CC2CC[C@@H](CCC(C)OC)O2)c1C(=O)O</smiles>

greensporone $\mathrm{E}$ (443)<smiles>COc1cc(O)c(Cl)c(CC(=O)/C=C\CCC(=O)CC[C@@H](C)O)c1C(=O)O</smiles>

greensporone B (436)<smiles>COc1cc(O)c(Cl)c(CC(=O)CCCCC(=O)CCC(C)O)c1C(=O)O</smiles>

8,9-dihydrogreensporone A (437)<smiles>[R]C(CCCCC(=O)Cc1c(OC)cc(O)cc1OC)CCC(C)OC(=O)c1ccccc1</smiles>

8,9-dihydrogreensporone $C\left(R^{1}=R^{2}=H\right)(441)$

8,9-dihydrogreensporone $\mathrm{D}\left(\mathrm{R}^{1}=\mathrm{Cl}, \mathrm{R}^{2}=\mathrm{OH}\right)(445)$

Figure 83. Structures of greensporones $435-448$ from the freshwater aquatic fungus Halenospora sp. [162].<smiles>[R]c1c(OC)cc(O)c(C(=O)c2c(O)cc(OC)cc2O)c1O</smiles>

stachybogrisephenone $A(R=H)(449)$ stachybogrisephenone $B(R=C l)(450)$<smiles>[R]c1c(OC)cc(OC)c(C(=O)c2c(OC)cc(O)cc2OC)c1O</smiles>

grisephenone $\mathrm{A}(\mathrm{R}=\mathrm{Cl})$

$(451)$<smiles>Cc1cc(O)cc2oc3cc(O)cc(O)c3c(=O)c12</smiles>

453

Figure 84. Structures of benzophenones 449-452 and xanthone 453 from Stachybotry sp. HH1 ZDDS1F1-2 [163].<smiles>COC1=CC(=O)C[C@H](C)[C@]12Oc1cc(O)cc(OC)c1C2=O</smiles>

454<smiles>COC1=CC(=O)[C@]2(Oc3c(Cl)c(OC)cc(OC)c3CC2=O)C(C)(O)C1</smiles>

455

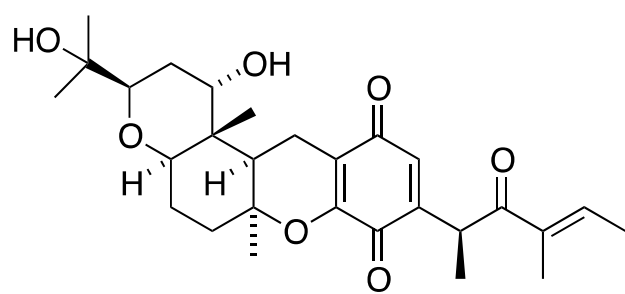

456

Figure 85. Structures of 454-456 from the fungus Nigrospora sp. MA75 [164]. 
The marine-derived Aspergillus sp. SCS10 FO63 fungus produces seven new averantin-type chlorinated anthraquinones 457-463 (Figure 86) along with five known analogues [165]. From this group, only 6-O-methyl-7-chloroaverantin (458) exhibits good cytotoxicity against SF-268 (glioblastoma), MCF-7 (breast), and NCI-H460 (lung) with IC50 values of 7.11, 6.64, and $7.42 \mu \mathrm{M}$, respectively. For comparison, cisplatin has IC50 values of $4.59,10.23$, and $1.56 \mu \mathrm{M}$, respectively.<smiles>[R10]c1cc2c(c(O)c1Cl)C(=O)c1c(cc(O)c([C@H]([R20])CCCCC)c1O)C2=O</smiles>

$457\left(R^{1}=R^{2}=H\right)$

$458\left(R^{1}=M e, R^{2}=H\right)$

$459\left(R^{1}=H, R^{2}=M e\right)$

$460\left(R^{1}=R^{2}=M e\right)$

$461\left(R^{1}=H, R^{2}=n-B u\right)$<smiles>[R6]Oc1cc2c(c(O)c1Cl)C(=O)c1c(cc(O)c(/C=C/CCCC)c1O)C2=O</smiles>

$462(\mathrm{R}=\mathrm{H})$

$463(\mathrm{R}=\mathrm{Me})$

Figure 86. Structures of chlorinated averantin anthraquinones $457-463$ from the fungus Aspergillus sp. SCS10 FO63 [165].

The Homaxinella sponge-derived fungus, Gymnascella dankaliensis, has furnished the new polyketide dankastatin C (464) (Figure 87) [166]. This compound displays pronounced cell growth inhibition of the murine P388 leukemia cell line with $\mathrm{EC}_{50} 57 \mathrm{ng} / \mathrm{mL}$ (comparable to 5-fluorouracil with $\mathrm{EC}_{50}$ $78 \mathrm{ng} / \mathrm{mL})$.

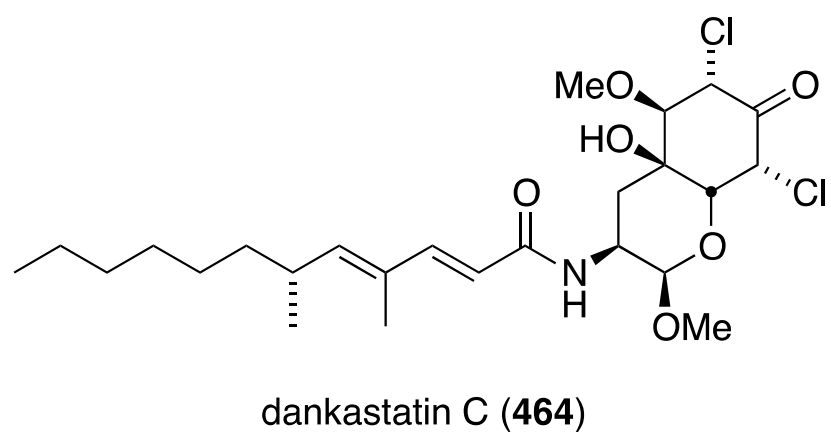

Figure 87. Structure of dankastatin C (464) from the fungus Gymnascella dankaliensis [166].

The seagrass (Thalassia hemprichii)-derived fungi Polyporales PSU-ES44 and PSU-ES83 have yielded the new polyporapyranones A-H (465-472) (Figure 88), along with eight known analogues [167]. Of these compounds, only 465 shows moderate activity against Vero cells (IC50 $6.93 \mu \mathrm{g} / \mathrm{mL}$ ), and no polyporapyranone is active against MCF-7 cells. For comparison, ellipticine has IC50 $1.28 \mu \mathrm{g} / \mathrm{mL}$ against these African green monkey kidney fibroblast (Vero) cells.

A strain of the fungus Chaetomium globosum, which was obtained from the marine fish Mugil cephalus, has produced three new azaphilones, chaetomugilin S (473), dechloro-chaetomugilin A (chaetomugilin T) (474), and dechloro-chaetomugilin D (chaetomugilin U) (475) (Figure 89) [168]. 
Chaetomugilin S (473) is modestly active towards these cell lines: P388, HL-60, L1210, and KB (IC50 46.0, 39.1, 43.7, and 34.5, respectively).<smiles>[R]c1cc(OC)c(-c2cc(=O)cco2)cc1[R]</smiles>

polyporapyranone $A\left(R^{1}=H, R^{2}=O M e\right)(465)$ polyporapyranone $B\left(R^{1}=\mathrm{OMe}, \mathrm{R}^{2}=\mathrm{H}\right)(\mathbf{4 6 6})$ polyporapyranone $C\left(R^{1}=R^{2}=\mathrm{OMe}\right)(467)$<smiles>[R]C1C=C(c2cc(=O)cco2)C([R])[C@H](O)C1[R]</smiles>

polyporapyranone $F\left(R^{1}=\alpha-O H, R^{2}=R^{3}=\beta-O H\right)(470)$ polyporapyranone $G\left(R^{1}=\beta-O H, R^{2}=R^{3}=\alpha-O H\right)(471)$<smiles>O=c1ccoc(-c2cc(O)cc(Cl)c2)c1</smiles>

polyporapyranone $\mathrm{D}(\mathbf{4 6 8 )}$<smiles>O=c1ccoc(C23OC2C2OC2C2OC23)c1</smiles>

polyporapyranone E (469)

Figure 88. Structures of polyporapyranones A-H (465-472) from the fungi Polyporales PSU-ES44 and PSU-ES83 [167].<smiles></smiles>

chaetomugilin S (473)<smiles></smiles>

chaetomugilin $\mathrm{T}(\mathrm{R}=\mathrm{OH})(\mathbf{4 7 4})$ chaetomugilin $U(R=H)(475)$

Figure 89. Structures of chaetomugilins $S, T$, and $U$ (473-475) from the fungus Chaetomium globosum [168].

Three new azaphilones, isochromophilones X-XII (476-478), have also been found in the fungus Diaporthe sp., which was isolated from the mangrove plant Rhizophora stylosa of Hainan Province, China (Figure 90) [169]. The familiar sclerotioramine and isochromophilone VI were also isolated. This is the first example of azaphilones being found in Diaporthe. Isochromophilone X (476) displays moderate cytotoxicity against MCF-7 (breast), SGC-7901 (gastric), SW1116 (colorectal), A549 (lung), and A375 (melanoma) with $\mathrm{IC}_{50}$ values of 14.90, 16.84, 24.15, 26.93, and 35.75 $\mu \mathrm{M}$. The other azaphilones have $>50 \mu \mathrm{M}$ against these cell lines. 
<smiles>[R2]N1C=C2C(=O)[C@]([R10])(O)C(=O)C(Cl)=C2C=C1/C=C/C(C)=C/[C@H](C)CC</smiles>

isochromophilone $X\left(\mathrm{R}^{1}=\mathrm{Ac}, \mathrm{R}^{2}=\mathrm{CH}_{2} \mathrm{CH}_{2} \mathrm{Ph}\right)(\mathbf{4 7 6})$ isochromophilone $\mathrm{XI}\left(\mathrm{R}^{1}=\mathrm{H}, \mathrm{R}^{2}=\mathrm{CH}_{2} \mathrm{CH}_{2} \mathrm{Ph}\right)(\mathbf{4 7 7})$<smiles>CC[C@H](C)/C=C(C)/C=C/C1=CC2=C(Cl)C(=O)[C@@](O)(OC(C)=O)C(=O)C2=CN1CCO</smiles>

isochromophilone XII (478)

Figure 90. Structures of isochromophilones X-XII (476-478) from the fungus Diaporthe sp. [169].

A marine-derived Penicillium sp., which was isolated from seawater on the French coast, has yielded an analogue of fumagillin, ligerin (479) (Figure 91) [170]. Evaluation of ligerin against these cancer cell lines: KB (nasopharyngeal), AT6-1 (murine prostatic), POS1 and OSRGa (murine osteosarcoma), and L929 (murine fibroblasts) shows antiproliferative activity against all of these cell lines except KB cells. The highest activity of ligerin is seen in the POS1 cell line (IC50 $117 \mathrm{nM}$ ), which is 20 times more active than the other cell lines. An Antarctic deep-sea fungus, Penicillium sp. PR19N-1, has yielded the four novel chlorine-containing sesquiterpenes 480-483 (Figure 91) [171]. The known non-chlorinated eremofortine $\mathrm{C}$ is also present.

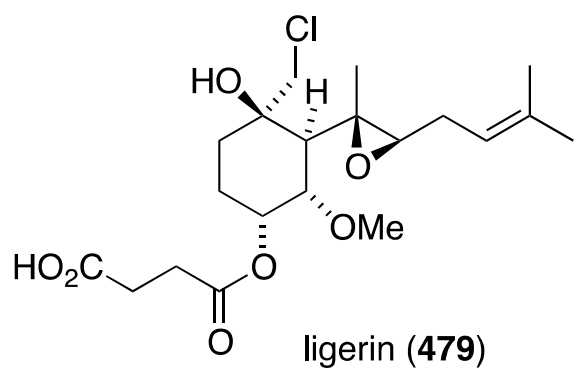<smiles>CC(=O)O[C@H]1C=C(Cl)C2=CC(=O)C(O)=C[C@@]2(C)[C@H]1C(C)(C)C</smiles><smiles>CC1[C@H](O)C=C(Cl)C2=CC(=O)C3(CC21C)OC3(C)CO</smiles><smiles>CC(C)=C1CC2(C)C(=CC1=O)[C@H](Cl)[C@H](O)C[C@@H]2C</smiles>

482<smiles>COC12C=C3[C@@H](Cl)[C@H](O)[C@@H](OC(C)=O)[C@H](C)[C@]3(C)C[C@@]13OCC2(C)O3</smiles>

483

Figure 91. Structures of ligerin (479) and 480-483 from the fungi Penicillium spp. [170,171].

Cyanobacteria continue to be a major supplier of novel natural products, including halogenated metabolites. The freshwater cyanobacterium Nostoc sp. (UIC 10274) from Illinois has afforded the two new carbamidocyclophanes F (484) and G (485) (Figure 92) [172], both of which are antiproliferative against the human cancer cell lines MDA-MB-435 (breast) and HT-29 (colon) with IC 50 0.5-0.7 $\mu \mathrm{M}$ for both 484 and $\mathbf{4 8 5}$. The cyanobacterium Fischerella sp. (SAG 46.79), a rich source of chlorinated indoles, contains the four new fischerindoles 486-489 (Figure 92) [173]. Of these four compounds only 487 (deschloro 12-epi-fischerindole I nitrile) shows (weak) cytotoxicity towards HT-29 cells (ED50 $23 \mu \mathrm{M}$ ). Compounds $\mathbf{4 8 8} / \mathbf{4 8 9}$ are the first carbazole-type fischerindoles to be discovered. 
<smiles>[R]C(c1cc(O)c([C@@H](CCCCC(Cl)Cl)CCCC(Cl)Cl)c(O)c1)[C@@H](C)CCCC[C@H](CCCC(Cl)Cl)c1c(O)cc([C@H](OC(N)=O)[C@@H](C)CCCC(Cl)Cl)cc1O</smiles>

$484(\mathrm{R}=\mathrm{OH})$ $485(R=O A c)$

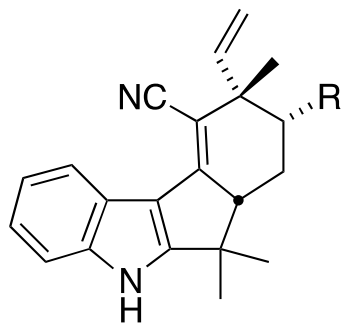

$486(\mathrm{R}=\mathrm{Cl})$ $487(\mathrm{R}=\mathrm{H})$<smiles>[R]C1Cc2cc(C)c3[nH]c4ccccc4c3c2[C@H](C#N)[C@@]1(C)C=C</smiles>

$488(\mathrm{R}=\mathrm{Cl})$ $489(\mathrm{R}=\mathrm{H})$

Figure 92. Structures of carbamidocyclophanes F (484) and G (485) from the cyanobacterium Nostoc sp., and fischerindoles $\mathbf{4 8 6}-\mathbf{4 8 9}$ from the cyanobacterium Fischerella sp. [172,173].

Lyngbya genus is a prolific producer of organohalogens and the Taiwanese Lyngbya majuscule has afforded the known isomalyngamide A (490) and the new isomeric A-1 (491) (Figure 93) [174]. Both compounds are antiproliferative towards MCF-7 and MDA-MG-231 cells (IC50 4.6 and $2.8 \mu \mathrm{M}$, respectively, for 490), and they inhibit the migration of MDA-MB-231 cells (IC50 0.060 and $0.337 \mu \mathrm{M}$, for 490 and 491, respectively). Consistent with an antimetastatic mechanism for these isomalyngamides is that they both inhibit $\alpha$-2,3-sialyltransferase (IC50 77.2 and $65.7 \mu \mathrm{M}$ for 490 and $\mathbf{4 9 1}$, respectively).

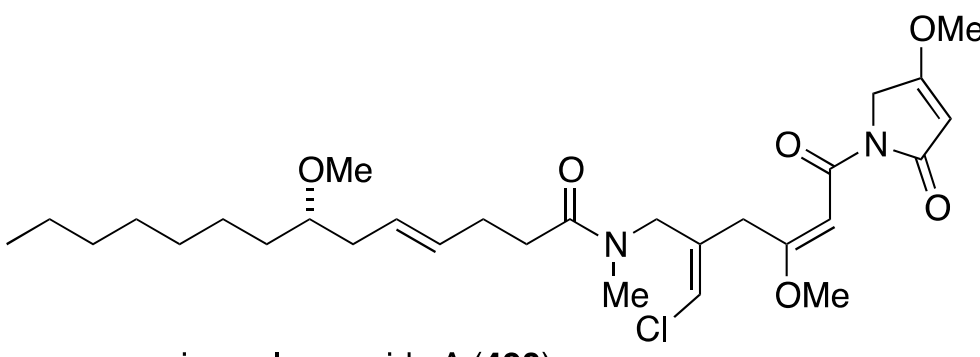

isomalyngamide $A(490)$

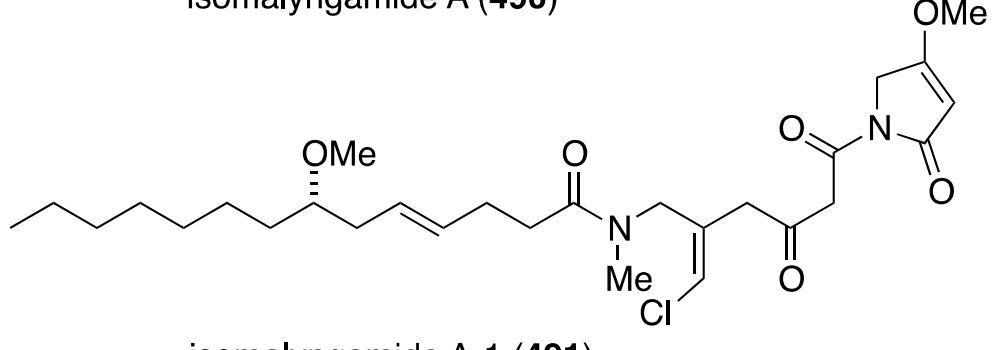

isomalyngamide $A-1$ (491)

Figure 93. Structures of isomalyngamides A (490) and A-1 (491) from the cyanobacterium Lyngbya majuscule [174].

The new malyngamide 2 (492) was characterized from a Papua New Guinea collection of Lyngbya sordida (Figure 94) [175]. Cytotoxicity towards H-460 (lung) is modest at IC $5021 \mu \mathrm{M}$. The Red Sea Moorea producens (formerly Lyngbya majuscula) produces malyngamide 4 (493) (Figure 94), along with five known analogues [176]. This compound is weakly inhibitory to the human cancer cell lines MDA-MB-231, A549, and HT-29 (GI 5044,40 , and $50 \mu \mathrm{M}$, respectively). 
<smiles>CCCCCCC[C@H](C/C=C/CCC(=O)NCC(=CCl)[C@H]1C(=O)[C@H](O)C[C@H](O)[C@H]1O)OC</smiles>

malyngamide 2 (492)<smiles>CCCCCCC[C@H](CCCCCCC(=O)N(C)CC(=CCl)CC(=CC(=O)N1CC=CC1=O)OC)OC</smiles>

malyngamide 4 (493)

Figure 94. Structures of malyngamides 2 (492) from Lyngbya sordida and 4 (493) from Moorea producens [175,176].

The previously presented coibacins A-D (297-300) from the Panamanian Oscillatoria sp. (Figure 53) show cytotoxicity against the H460 (lung) human cancer cell line, with coibacin D having the highest activity (IC50 $11.4 \mu \mathrm{M}$ ) [114]. A collection of Moorea bouillonii from the Palmya Atoll in the Central Pacific Ocean has led to the discovery of five novel lyngbyabellins, 494-498 (Figure 95) [177]. Lyngbyabellin N (498) is very similar to the known lyngbyabellin H. Although 494-497 are inactive in the H-460 cytotoxicity screen, 498 shows a range of activity in this cell line, IC50 $0.0048-1.8 \mu \mathrm{M}$, which may result from solubility difficulties in the assay medium. However, in the HCT-116 colon cancer cell line, 498 gives the reproducible and very potent $\mathrm{IC}_{50} 40.9 \pm 3.3 \mathrm{nM}$.

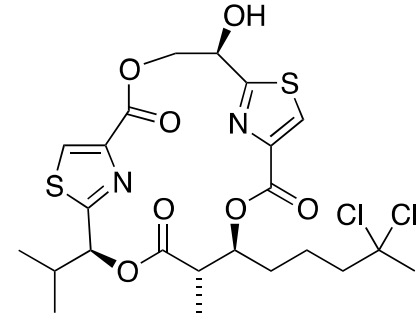

lyngbyabellin K (494)

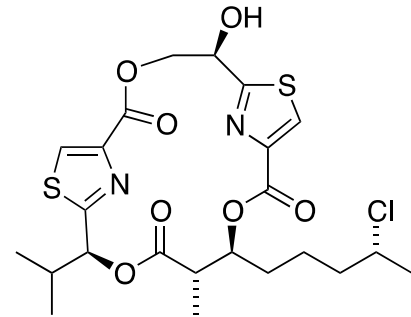

lyngbyabellin L (495)<smiles>CCOC(=O)c1csc(C(OC(=O)[C@H](CCCC(C)Cl)OC(=O)c2csc([C@H](O)CCC(C)Cl)n2)C(C)C)n1</smiles>

7-epi-lyngbyabellin L (496)<smiles>CCOCc1csc([C@H](O)COC(=O)c2csc([C@@H](OC(=O)[C@H](C)[C@H](O)CCCC(C)(Cl)Cl)C(C)C)n2)n1</smiles>

lyngbyabellin M (497)

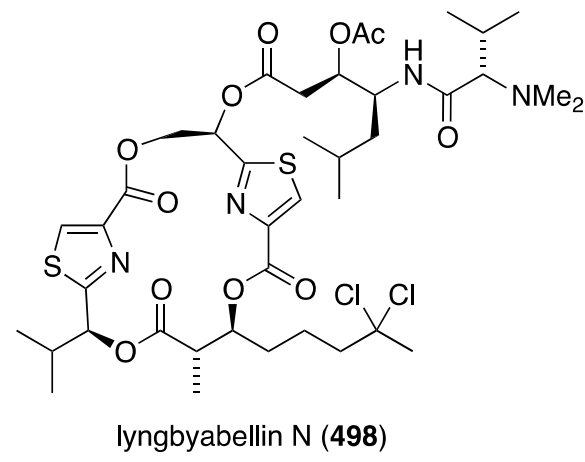

Figure 95. Structures of lyngbyabellins 494-498 from the cyanobacterium Moorea bouillonii [177]. 
Like terrestrial bacteria, marine bacteria can synthesize extremely complex natural products, most notably by marine-derived Streptomyces sp. A Bahamas marine sediment has provided Streptomyces variabillis (SNA-020) that produces ammosamide D (499) (Figure 96) [178]. This newest member of the ammosamide family has modest activity in the human cancer cell line MIA PaCa-2 (pancreas), IC50 $3.2 \mu \mathrm{M}$. Similarly, a marine sediment from the San Clemente, California, coast has yielded chlorizidine A (500) (Figure 96) [179]. This metabolite, with the unprecedented $5 H$-pyrrolo[2,1-a]isoindol-5-one ring system, is strongly cytotoxic to the human cell line HCT-116 (colon), IC50 3.2-4.9 $\mu \mathrm{M}$.<smiles>CNC(=O)c1cc(C(N)=O)nc2c1C(=O)C(=O)C(Cl)=C2N</smiles>

ammosamide D (499)<smiles>O=C1c2c(cc(O)c([C@@H]3CCc4cc(Cl)c(Cl)n43)c2O)-c2cc(Cl)c(Cl)n21</smiles>

chlorizidine A (500)

Figure 96. Structures of Streptomyces sp. ammosamide D (499) and chlorizidine A (500) [178,179].

The earlier discussed strepchloritides A (46) and B (47) (Figure 7), from Streptomyces sp. OUCMDZ-1703, are cytotoxic against the MCF-7 (breast) cell line; IC50 9.9 and $20.2 \mu \mathrm{M}$, respectively [42]. The deep-sea derived Streptomyces sp. SCS10 03032 has provided the remarkable spiroindimicins A-D (501-504) (Figure 97) [180]. Spiroindimicin B (502) shows moderate activity against B16 (mouse melanoma), H460 (human lung), and CCRF-CEM (human leukemia): 5, 12, and $4 \mu \mathrm{g} / \mathrm{mL}$, respectively. Spiroindimicin C (503) towards HepG2 (human hepatocellular liver) and H460 gives: 6 and $15 \mu \mathrm{g} / \mathrm{mL}$, respectively. Spiroindimicin D (504) is slightly less active, and A (501) is inactive in all five cell lines, including MCF-7 (breast). For comparison, 5'-hydroxystaurosporine shows IC50 values of 8, 2, 8, and $5 \mu \mathrm{g} / \mathrm{mL}$ for HepG2, B16, H460, and CCRF-CEM, respectively. This same Streptomyces sp. contains indimicins A-E (505-509) and lynamicins F (510) and G (511) (Figure 97) [181]. Of this collection, only indimicin B (506) is cytotoxic to the MCF-7 cell line, IC50 $10.0 \mu \mathrm{M}$. No cytotoxicity is observed for the other indimicins when tested against SF268, MCF-7, H460, and HepG2.

The aforementioned napyradiomycins 184-193 (Figures 30 and 31) [75,76] display antitumor activity towards the human colon cell line HCT-116 with these cytotoxicity values ( $\mathrm{IC}_{50} \mu \mathrm{g} / \mathrm{mL}$ ): napyradiomycin A (184) (4.19), B (185) (>20), C (186) (>20), D (187) (16.1), E (188) (4.81), F (189) (9.42), B2 (3.18), B3 (190) (0.19), and B4 (1.41) [75]. The effect of chlorine on the cytotoxicity is noteworthy (i.e., napyradiomycins A vs. B, and F vs. B2). A La Jolla, California, coastal sediment has afforded the actinomycete strain CNQ525, which produces the novel napyradiomycins 512-515 (Figure 98) [182]. Assays of these compounds against the HCT-116 human colon cell line are as follows for the most active napyradiomycins ( $\mathrm{IC}_{50} \mu \mathrm{M}$ ): CNQ525.538 (514) (6), B1 (2), B3 (190) (3), A80915A (3), A80915B (<1), and A809150 (<1). The etoposide control has $1 \mu \mathrm{M}$. 
<smiles>COC(=O)c1[nH]c(C(=O)OC)c2c1C1=CNC3=CC=C(Cl)C=C1[C@]32C=Nc1ccc(Cl)cc1</smiles>

spiroindimicin A (501)<smiles>[R2]c1[nH]c(C(=O)OC)c2c1-c1c([nH]c3ccc(Cl)cc13)[C@@]21CN([R7])c2ccc(Cl)cc21</smiles>

spiroindimicin $B\left(R^{1}=M e, R^{2}=H\right)(502)$

spiroindimicin $C\left(R^{1}=R^{2}=H\right)(\mathbf{5 0 3})$

spiroindimicin $\mathrm{D}\left(\mathrm{R}^{1}=\mathrm{Me}, \mathrm{R}^{2}=\mathrm{CO}_{2} \mathrm{Me}\right)(504)$<smiles>[R2]c1c2c(cn1[R17])[C@@]1(C)c3cc(Cl)ccc3N(C)[C@H]1c1[nH]c3ccc(Cl)cc3c1-2</smiles><smiles>CN1C[C@](C)(c2cn(C)cc2-c2c[nH]c3ccc(Cl)cc23)c2cc(Cl)ccc21</smiles>

indimicin $A\left(R^{1}=M e, R^{2}=H\right)(505)$ indimicin $B\left(R^{1}=R^{2}=M e\right)(506)$ indimicin $C\left(R^{1}=H, R^{2}=M e\right)(507)$ indimicin $D\left(R^{1}=R^{2}=H\right)(508)$<smiles>[R]c1c(-c2c[nH]c3ccc(Cl)cc23)c(-c2c[nH]c3ccc(Cl)cc23)c(C(=O)OC)n1C</smiles>

lynamicin $F(R=H)(510)$ lynamicin $\mathrm{G}\left(\mathrm{R}=\mathrm{CO}_{2} \mathrm{Me}\right)(\mathbf{5 1 1})$

Figure 97. Structures of spiroindimicins A-D (501-504) and indimicins A-E (505-509) and lynamicins F (510) and G (511) from Streptomyces sp. SCS10 03032 [180,181].

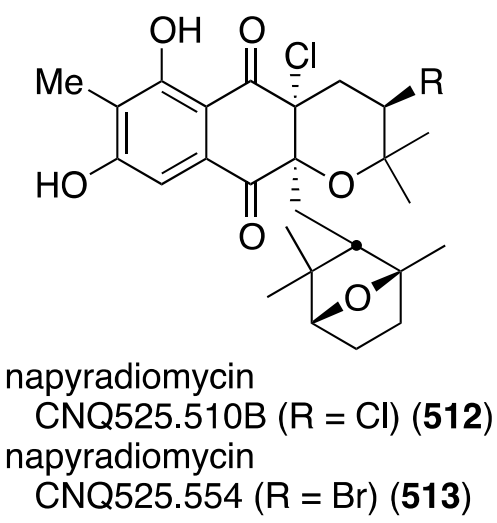<smiles>CC(C)=CCC/C(C)=C/C[C@]12OC(C)(C)[C@@H](Br)C[C@]1(Cl)C(=O)c1c(cc(O)c(C)c1O)C2=O</smiles><smiles>Cc1c(O)cc2c(c1O)C(=O)[C@@H]1C[C@H](Br)C(C)(C)O[C@]1(C)C2=O</smiles>

Figure 98. Structures of napyradiomycins 512-515 from actinomycete strain CNQ525 [182].

The thermophilic bacterium Thermovibrio ammonificans, collected from the walls of a deep-sea hydrothemal vent on the East Pacific Rise, has provided two additional ammonificins, C (516) and D (517) (Figure 99) [183]. The ortho dibromophenyl ring is unique amongst natural organohalogens. Both ammonificins $\mathrm{C}$ and $\mathrm{D}$ induce apoptosis at 2 and $3 \mu \mathrm{M}$, respectively, in a standard apoptosis assay with W2 and D3 cells. 


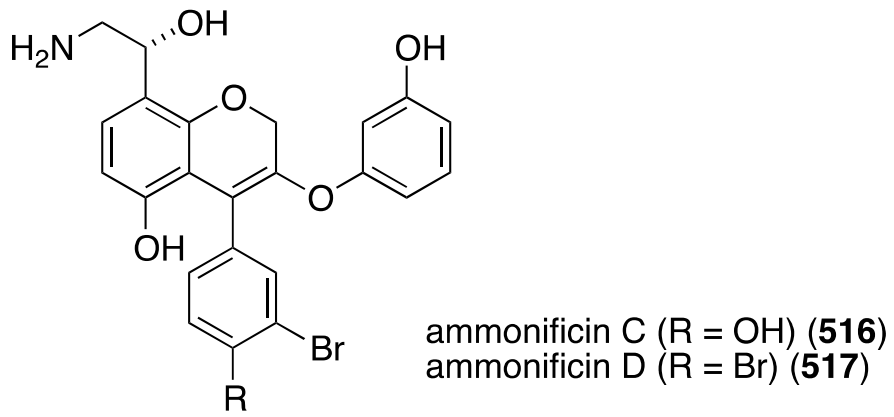

Figure 99. Structures of ammonificins C (516) and D (517) from Thermovibrio ammonificans [183].

Despite their bland appearance, bryozoans ("moss animals") are the repository of incredibly complex natural products, many of which are heavily brominated. The Patagonian bryozoan Aspidostoma giganteum contains a wealth of such organobromines, the aspidostomides A-H (518-525) and aspidazide A (526) (Figure 100) [184]. The only cytotoxic member $\left(\mathrm{IC}_{50}<10 \mu \mathrm{M}\right)$ of this collection is aspidostomide $\mathrm{E}(\mathbf{5 2 2})$, which displays $\mathrm{IC}_{50} 7.8 \mu \mathrm{M}$ towards the human cell line $786-\mathrm{O}$ (renal carcinoma).<smiles>[R]c1[nH]c(C(=O)NCC(O[Tl])c2cc(Br)c(O)c(Br)c2)c([R])c1Br</smiles>

aspidostomide $A\left(R^{1}=R^{2}=H, R^{3}=B r\right)(518)$ aspidostomide $B\left(R^{1}=R^{3}=H, R^{2}=B r\right)(519)$ aspidostomide $C\left(R^{1}=H, R^{2}=R^{3}=B r\right)(520)$<smiles></smiles>

aspidostomide $D(R=H)(521)$ aspidostomide $E(R=M e)(522)$<smiles>O=c1[nH]cc(-c2c(Br)[nH]c3ccc(Br)cc23)n2c(Br)c(Br)c(Br)c12</smiles>

aspidostomide $F$ (523)<smiles>O=C(NCCc1c(Br)[nH]c2cc(Br)cc(O)c12)c1cc(Br)c(Br)[nH]1</smiles>

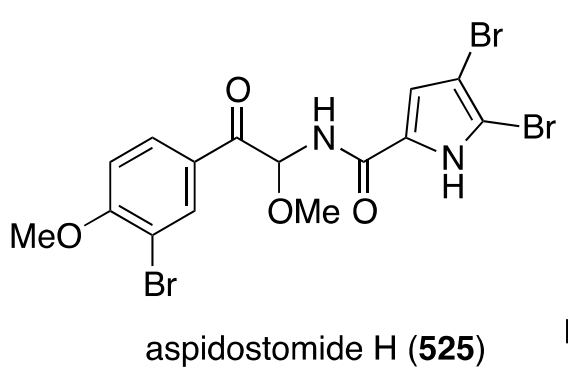

aspidostomide $\mathrm{G}$ (524)<smiles>O=c1c2c(Br)c(Br)cn2c(-c2cc(Br)c(O)c(Br)c2)cn1-n1cc(-c2cc(Br)c(O)c(Br)c2)n2c(Br)c(Br)cc2c1=O</smiles>

aspidazide $\mathrm{A}$ (526)

Figure 100. Structures of aspidostomides A-H (518-525) and aspidazide A (526) from the bryozoan Aspidostoma giganteum [184].

The Indian Ocean nudibranch, Aldisa andersoni, has afforded two phorbazoles, 9-chlorophorbazole D (527) and N1-methylphorbazole A (528) (Figure 101), in addition to the known phorbazoles A, B, 
and D [185]. Both new phorbazoles show modest growth inhibition against the human cell lines A549, MCF-7, SKMEL-28 (melanoma), Hs683 (oligodendroglioma), and U373 (glioblastoma) in the range of $\mathrm{IC}_{50} 18-29 \mu \mathrm{M}$ and $19-34 \mu \mathrm{M}$ for $\mathbf{5 2 7}$ and 528, respectively. These data are comparable or superior to the $\mathrm{IC}_{50}$ levels observed with carboplatin and temozolomide.<smiles>Oc1ccc(-c2oc(-c3[nH]ccc3Cl)nc2Cl)cc1</smiles>

9-chlorophorbazole D (527)<smiles>Cn1cc(Cl)c(Cl)c1-c1nc(Cl)c(-c2ccc(O)cc2)o1</smiles>

N-1-methylphorbazole A (528)

Figure 101. Structures of phorbazoles 527 and $\mathbf{5 2 8}$ from the nudibranch Aldisa andersoni [185].

The Antarctic nudibranch Austrodoris kerguelenensis, collected near Palmer Station, produces sixteen new and some old diterpenoid glyceride esters, the palmadorins, several of which inhibit human erythroleukemia (HEL) cells. These are palmadorins A (529), B (530), D (531), M (532), $\mathrm{N}$ (533), and O (534) (Figure 102) [186]. One contains chlorine, the inactive palmadorin L (535) (Figure 102) [186]. The growth inhibition data for the active palmadorins are (IC50 $\mu \mathrm{M})$ : A (8.7), B (8.3), D (16.5), M (4.9), N (6.3), and O (13.4), respectively.

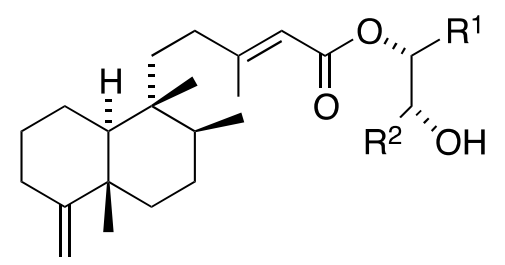

palmadorin $\mathrm{A}\left(\mathrm{R}^{1}=\mathrm{CH}_{2} \mathrm{OH}, \mathrm{R}^{2}=\mathrm{H}\right)(529)$ palmadorin $\mathrm{B}\left(\mathrm{R}^{1}=\mathrm{CH}_{2} \mathrm{OAc}, \mathrm{R}^{2}=\mathrm{H}\right)(530)$ palmadorin $\mathrm{D}\left(\mathrm{R}^{1}=\mathrm{H}, \mathrm{R}^{2}=\mathrm{CH}_{2} \mathrm{OH}\right)(531)$<smiles>[R2]C(O)[C@H](O)OC(=O)/C=C1\C=C2CC[C@@H]3C(C)(C)CCC[C@]3(C)[C@@H]2CC1</smiles>

palmadorin $\mathrm{M}\left(\mathrm{R}^{1}=\mathrm{CH}_{2} \mathrm{OH}, \mathrm{R}^{2}=\mathrm{H}\right)(532)$ palmadorin $\mathrm{N}\left(\mathrm{R}^{1}=\mathrm{H}, \mathrm{R}^{2}=\mathrm{CH}_{2} \mathrm{OH}\right)(533)$ palmadorin $\mathrm{O}\left(\mathrm{R}^{1}=\mathrm{CH}_{2} \mathrm{OAc}, \mathrm{R}^{2}=\mathrm{H}\right)(\mathbf{5 3 4})$

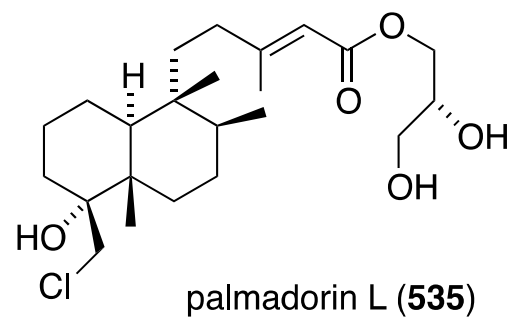

Figure 102. Structures of palmadorins (529-535) from the nudibranch Austrodoris kerguelenensis [186].

Larger marine animals like gastropod molluscs are known to produce biologically active metabolites, some of which contain halogen. The anticancer properties of the lamellarins, which were first isolated from a marine mollusc, have been reviewed [187].

The Australian gastropod Dicathais orbita contains the well-known 6-bromoisatin which is active against the human cancer cell lines HT-29 and Caco2. It inhibits cell cycle progression of HT-29 cells 
by arresting some cells in the G2/M phase, and induces apoptosis [188,189]. The Egyptian sea hare Aplysia oculifera has provided two new halogenated sesquiterpenes, oculiferane (536) and epi-obtusane (537) (Figure 103) [190]. Both compounds are cytotoxic ( $\mathrm{IC}_{50}<10 \mu \mathrm{g} / \mathrm{mL}$ ) to the human cell lines PC-3 (prostate), A549, MCF-7, HepG2, and HCT 116, with these IC50 values (536/537): $3.9 / 3.1,3.1 / 0.96,5.6 / 5.9,3.3 / 2.4$, and $5.9 / 4.1 \mu \mathrm{g} / \mathrm{mL}$, respectively. $\mathbf{5 3 7}$ is comparable to 5-fluorouracil against A-549 (0.96 vs. $0.90 \mu \mathrm{g} / \mathrm{mL})$.

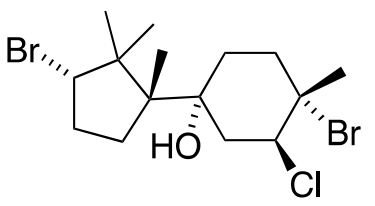

oculiferane (536)

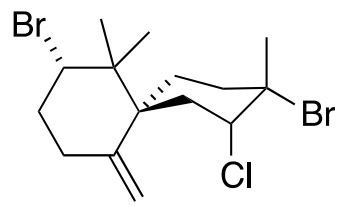

epi-obtusane (537)

Figure 103. Structures of oculiferane (536) and epi-obtusane (537) from the sea hare Aplysia oculifera [190].

\section{Antioxidants and Antiinflammation}

Because antioxidants can have anti-inflammatory activity, these two categories are combined.

Like terrestrial phenolic compounds, marine phenols with antioxidant properties are well known, and several recent examples have appeared. The red alga Rhodomela confervoides from Liaoning Province, China, has afforded 19 bromophenols, six of which are new (538-543) (Figure 104) [191]. Two known examples, $\mathbf{5 4 4}$ and $\mathbf{5 4 5}$, are included because they are active in the radical scavenging assays. All 19 bromophenols were subjected to both the DPPH (1,1-diphenyl-2-picrylhydrazyl) and the ABTS (2,2'-azinobis(3-ethylbenzothiazoline-6-sulfonic acid)diammonium salt) free radical scavenging assays. Most of the bromophenols display more potent antioxidant activity than either BHT (butylated hydroxytoluene) or ascorbic acid. For the DPPH assay the most active compound is $\mathbf{5 3 9}\left(\mathrm{IC}_{50} 7.43 \mu \mathrm{M}\right)$ followed by $\mathbf{5 4 4}>\mathbf{5 4 3}>\mathbf{5 4 5}>\mathbf{5 3 8}$. In the ABTS assay $\mathbf{5 4 3}$ is the most active, followed by $544>545>541$.<smiles>CS(=O)(=O)Cc1cc(O)c(O)c(Br)c1Br</smiles>

538<smiles>OCC(O)COCc1cc(O)c(O)c(Br)c1Br</smiles>

539<smiles>[R]c1c(/C=C/C(C)=O)cc(O)c(O)c1[R]</smiles>

$$
\begin{aligned}
& 543\left(R^{1}=B r, R^{2}=H\right) \\
& 544\left(R^{1}=R^{2}=B r\right) \\
& 545\left(R^{1}=H, R^{2}=B r\right)
\end{aligned}
$$<smiles>[2H]Cc1cc(O)c(O)c(Br)c1Br</smiles>

$540\left(\mathrm{R}=\mathrm{NH}_{2}\right)$ $541\left(\mathrm{R}=\mathrm{CO}_{2} \mathrm{H}\right)$<smiles>COc1c(O)cc(CO)cc1Br</smiles>

542

Figure 104. Structures of bromophenols 538-545 from the alga Rhodomela confervoides [191]. 
Another study of Rhodomela confervoides has led to the discovery of five new nitrogen-containing bromophenols 546-550 (Figure 105) in addition to nine known analogues such as $\mathbf{5 5 1}$ [192]. In the DPPH assay bromophenol 546 shows the strongest activity (IC50 $5.22 \mu \mathrm{M})$ (BHT, IC50 82.1 $\mu \mathrm{M}$ ), followed by $\mathbf{5 4 8}>\mathbf{5 4 7}>\mathbf{5 5 1}$. In the ABTS assay, $\mathbf{5 5 1}$ is the most active, more active than ascorbic acid. The antioxidant capacity of these bromophenols seems to be correlated with the number of hydroxyl groups (or phenolic rings).<smiles>O=C1C[C@H](Cc2cc(O)c(O)c(Br)c2Br)C(=O)N1</smiles>

546<smiles>[R]OC(=O)CCC(=O)NCc1cc(O)c(O)c(Br)c1Br</smiles>

$547(\mathrm{R}=\mathrm{Me})$

$548(R=H)$<smiles>[R]c1cc(O)c(OC)c(Br)c1</smiles>

$549\left(\mathrm{R}=\mathrm{CONH}_{2}\right)$ $550\left(\mathrm{R}=\mathrm{CH}_{2} \mathrm{CONH}_{2}\right)$

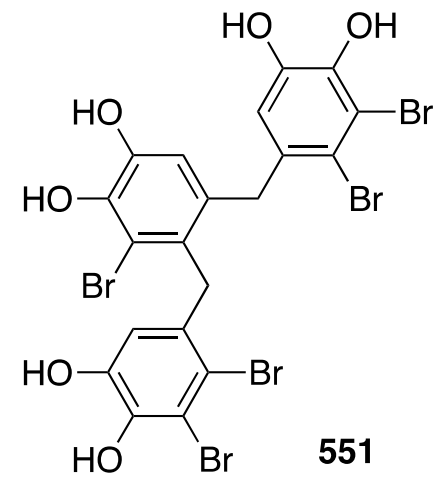

Figure 105. Structures of bromocatechols 546-551 from the alga Rhodomela confervoides [192].

A specimen of the red alga Symphyocladia latiuscula from the coast of Qingdao, Shandong Province, China, has furnished the new bromocatechols 552 and 553 (Figure 106) [193]. Both are modest radical scavengers in the DPPH assay with $\mathrm{IC}_{50} 14.5$ and $20.5 \mu \mathrm{g} / \mathrm{mL}$, respectively. Ascorbic acid shows $\mathrm{IC}_{50} 7.82 \mu \mathrm{g} / \mathrm{mL}$. The red alga Vertebrata lanosa, collected from Ullsfjorden, Norway, afforded the new bromocatechol 554 and the known 555-557 (Figure 106) [194]. Their antioxidant capacity was screened using these assays: ORAC (oxygen radical absorbance capacity), CAA (cellular antioxidant activity), and CLPAA (cellular lipid peroxidation antioxidant activity). This study is the first to measure the cellular antioxidant activity of bromocatechols. The antioxidant activity is highest for $\mathbf{5 5 5}$ followed by 554, and then $\mathbf{5 5 6}$ and 557. At concentrations as low as $10 \mu \mathrm{g} / \mathrm{mL}$, bromocatechol $\mathbf{5 5 5}$ inhibits $68 \%$ of oxidation in the CAA assay. By comparison, the known antioxidants quercetin and luteolin at this same concentration $(10 \mu \mathrm{g} / \mathrm{mL})$ inhibit the oxidation of the CAA substrate $\left(2^{\prime}, 7^{\prime}\right.$-dichlorofluorescin) to the extent of $92 \%$ and $58 \%$, respectively.

Several marine sponges exhibit antioxidant behavior. The new 5,6-dibromo-L-hypaphorine (558) (Figure 107), along with four known bromoindoles, was isolated from the sponge Hyrtios sp. living in Fiji [195]. This new bromoindole displays significant antioxidant ability in the ORAC assay, only 4-fold less active than Trolox (a water-soluble analogue of Vitamin E). A study of the antioxidant activity of the known Zyzzya fuliginosa sponge metabolites, zyzzyanones and makaluvamines reveals that the presence of a phenolic ring is essential for maximum activity in both the ABTS and APPH assays, and that a $p$-hydroxystyryl unit as in the makaluvamines (e.g., 559) is more important than a simple phenolic ring as in the zyzzyanones (e.g., 560) (Figure 107) [196]. 
<smiles>CC(C)(C)S(=O)(=O)c1c(O)c(O)c(Br)c(Br)c1CNC(=O)NCc1c(Br)c(O)c(O)c(Br)c1Br</smiles>

555<smiles>COC(=O)C(=CC(=O)O)C(Cc1cc(Br)c(O)c(O)c1Br)C(=O)O</smiles>

553<smiles>Oc1cc(COCc2cc(O)c(Br)c(Br)c2Br)c(Br)c(Br)c1O</smiles><smiles>O=Cc1cc(O)c(O)c(Br)c1Br</smiles><smiles>CCCCCCc1cc(O)c(O)c(Br)c1Cc1cc(O)c(O)c(Br)c1Cc1cc(O)c(O)c(Br)c1Cc1cc(O)c(O)c(Br)c1Br</smiles>

556

Figure 106. Structures of bromocatechols 552-556 from the red algae Symphyocladia latiuscula and Vertebrata lanosa [193,194].<smiles>CN(Cc1c[nH]c2cc(Br)c(Br)cc12)C(=O)[O-]</smiles>

5,6-dibromo-L-hypaphorine (558)<smiles></smiles>

makaluvamine C (559)

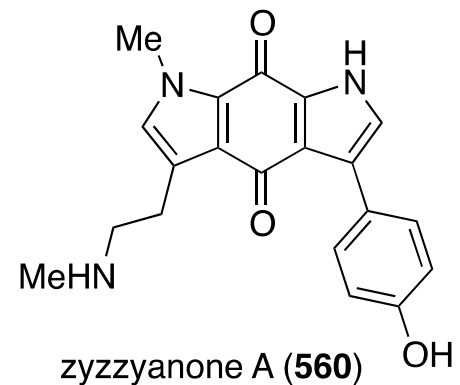

Figure 107. Structures of 558-560 from the sponges Hyrtios sp. and Zyzza fuliginosa [195,196].

The novel iodinated acetylenic acid sponge metabolites 561-564, isolated from the South Korean Suberites mammilaris (561 and 562) and Suberites japonicus (563 and 564), were examined for their antiinflammatory activity (Figure 108) [197]. The methyl esters 561 and 562 strongly inhibit nitric oxide (NO) production from RAW 264.7 murine macrophase cells, with $\mathrm{IC}_{50} 3.9$ and $7.0 \mu \mathrm{M}$, respectively. However, in BV2 microglia cells, the methyl esters of 563 and 564 are the most active in NO inhibition: IC50 3.1 and $1.8 \mathrm{M}$, respectively. All four methyl esters attenuate the production of PGE2 (prostaglandin E2) from RAW 264.7 and BV2 cells as induced by LPS (lipopolysaccharide).

The previously cited 4,5,6-tribromo-2,3-bis(methylthio)indole (121) (Figure 21) dramatically reduces the expression of both the pro-inflammatory enzyme $i$-NOS (inducible nitric oxide synthase) and COX-2 (cyclooxygenase) in LPS-activated RAW 264.7 cells. This indole has superior antiinflammatory activity relative to the other bromoindoles in this study [62]. Likewise, pitinoic acid B (199) (Figure 33) in LPS-stimulated differentiated THP-1 (human acute monocytic leukemia) cells decreases the level of the pro-inflammatory cytokines TNF- $\alpha$ (tumor necrosis factor alpha) and IL-6 (interleukin 6), which probably accounts for the antiinflammatory effects of 200 [79]. Coibacin B (298) (Figure 53) also inhibits the gene transcription of the cytokines TNF- $\alpha$, IL-6, IL-1b, and $i$-NOS. In the latter assay for $\mathrm{NO}$ production 298 has $\mathrm{IC}_{50} 5 \mu \mathrm{M}$ [114]. The didemnins from the tunicate 
Trididemnum solidum (Figure 80 ) have pronounced antiinflammatory activity, particularly didemnin B (405), which inhibits $i$-NOS and NF-kB (nuclear factor-kappa B) expression, with IC50 0.002 and $0.03 \mu \mathrm{M}$, respectively. Chlorinated didemnin $\mathbf{4 0 2}$ shows $\mathrm{IC}_{50} 0.4$ and $0.26 \mu \mathrm{M}$, respectively [159]. Malyngamide 2 (492) (Figure 94) has a value of IC $508.0 \mu \mathrm{M}$ in LPS-induced RAW 264.7 macrophages for the inhibition of NO production [175]. The herdmanines A-D (565-568) (Figure 109) from the Korean ascidian Herdmania momus inhibit the mRNA expression of $i$-NOS, and thereby suppress NO production with $\mathrm{IC}_{50}$ values of 90 and $9 \mu \mathrm{M}$, for $\mathbf{5 6 7}$ ad 568, respectively. These two herdmanines also inhibit $\mathrm{PGE}_{2}$ production via the reduced mRNA expression of COX-2, and herdmanine D (568) inhibits the mRNA expression of IL-6 [198].<smiles>C=CC=CCC(I)=CCC#CCC=CCC(I)=CCCCC(=O)O</smiles>

561

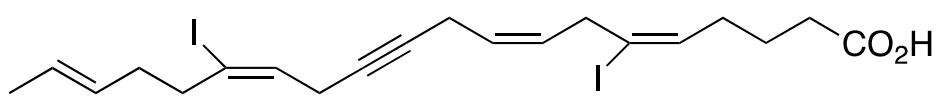

562

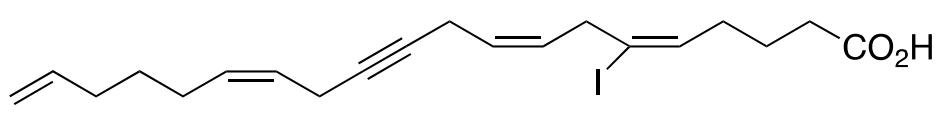

563

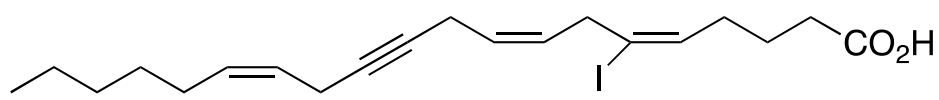

564

Figure 108. Structures of iodinated acetylenic acids 561-564 from the sponges Suberites mammilaris and S. japonicus [197].<smiles>[R]c1ccc2c(C(=O)Oc3ccc(C(=O)NC(CCCNC(=N)N)C(=O)O)cc3)c[nH]c2c1</smiles><smiles>N=C(N)NCCCC(NC(=O)c1ccc(OC(=O)c2ccc(O)cc2)cc1)C(=O)O</smiles><smiles>NC(Cc1ccc(OC(=O)c2c[nH]c3cc(Br)c(O)cc23)cc1)C(=O)O</smiles>

Figure 109. Structures of herdmanines A-D (565-568) from the ascidian Herdmania momus [198]. 
The Taiwanese gorgonian Junceella fragilis has afforded eight new 8-hydroxybriarane diterpenoids, frajunolides L-O (569-572) [199] and P-S (573-576) [200] (Figure 110). The antiinflammatory activities of these frajunolides were examined by measuring superoxide generation and elastase release by human neutrophils in response to fMLP/CB (formylmethionyl-leucyl-phenylalanine/ dihydrocytochalasin B. These data are summarized in Table 17. A similar set of briarane diterpenoids was characterized in the gorgonian Junceella juncea, juncenolides M-O (577-579) (Figure 111) [201]. The antiinflammatory activity of these juncenolides is shown in Table 17. Of the frajunolides L-S, P and $\mathrm{Q}$ are the most active on both superoxide anion generation and elastase release. Of the juncenolides $\mathrm{M}-\mathrm{O}, \mathrm{O}$ is the most active and $\mathrm{N}$ shows inhibition against elastase release. The gorgonian Briareum sp. collected in Taiwan yielded the novel dichlorinated briarenolide J (580) (Figure 111), which also displays antiinflammatory activity (Table 17) [202]. It would appear that frajunolide $\mathrm{S}$ (576) is identical with juncenolide M (577).

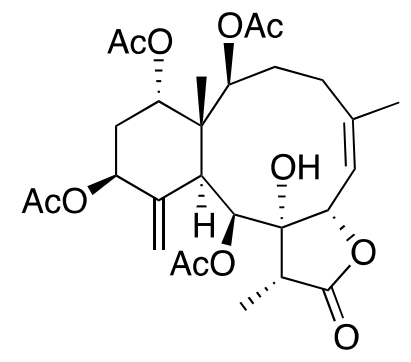

frajunolide $L$ (569)

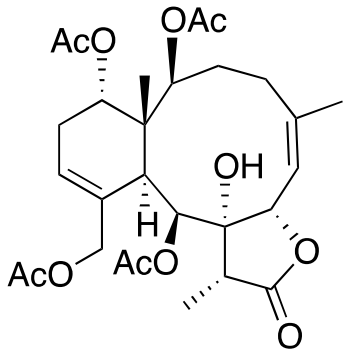

frajunolide $M(\mathbf{5 7 0})$

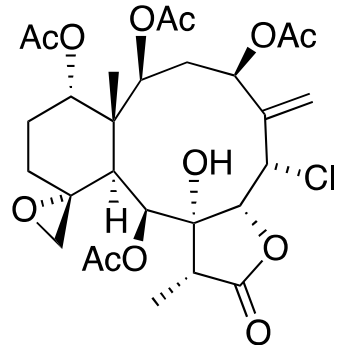

frajunolide N (571)

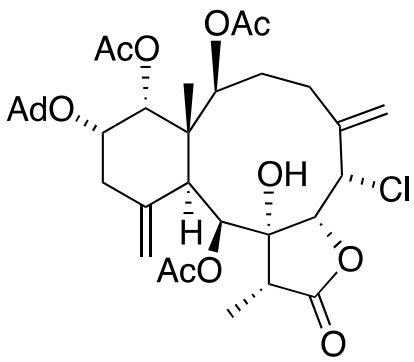

frajunolide $\mathrm{O}(\mathbf{5 7 2})$

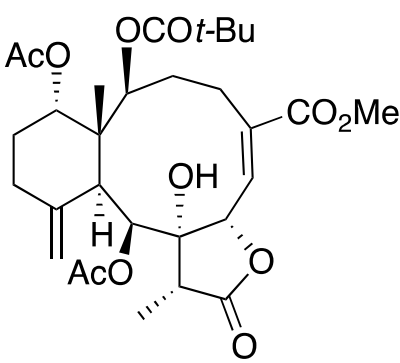

frajunolide $P$ (573)

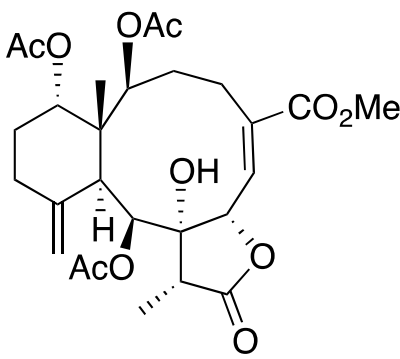

frajunolide Q (574)

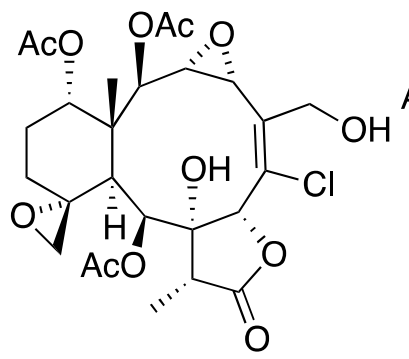

frajunolide $R$ (575)

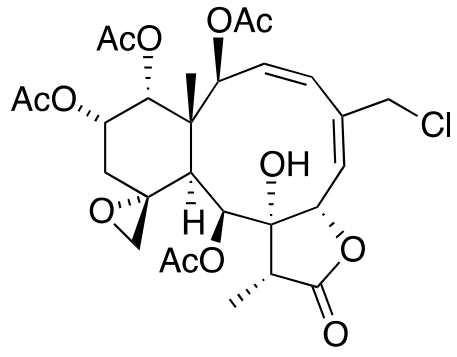

frajunolide $S$ (576)

Figure 110. Structures of frajunolides L-S (569-576) from the gorgonian Junceella fragilis [199,200].

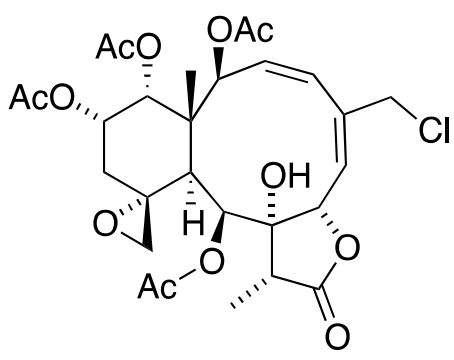

juncenolide M (577)

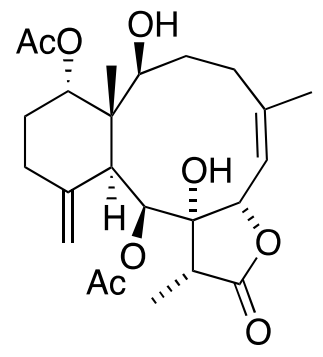

juncenolide N (578)

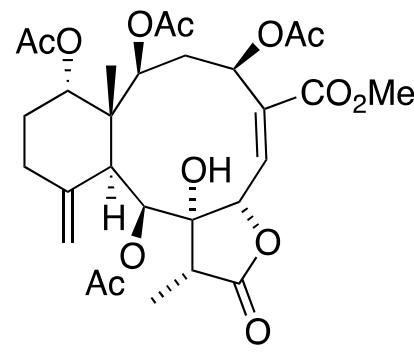

juncenolide $O$ (579)

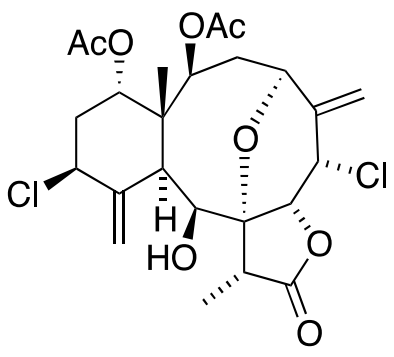

briarenolide J (580)

Figure 111. Structures of juncenolides $\mathrm{M}-\mathrm{O}$ (577-579) from the gorgonian Junceella juncea [201]. 
Table 17. Effect of frajunolides L-S (569-576), juncenolides $\mathrm{M}-\mathrm{O}$ (577-579), and briarenolide $\mathrm{J}$ (580) on superoxide anion generation and elastase release in response to $\mathrm{fMLP} / \mathrm{CB}$.

\begin{tabular}{ccc}
\hline & \multicolumn{2}{c}{ \% Inhibition $^{\text {a }}$} \\
\hline Compound & Superoxide Anion & Elastase Release \\
\hline frajunolide L (569) & 18.7 & 16.2 \\
frajunolide M (570) & 2.0 & 13.3 \\
frajunolide N (571) & 0.6 & 22.3 \\
frajunolide O (572) & 8.3 & 17.2 \\
frajunolide P (573) & 32.5 & 35.6 \\
frajunolide Q (574) & 28.7 & 34.1 \\
frajunolide R (575) & 9.7 & 16.0 \\
frajunolide S (576) & 5.8 & -4.5 \\
juncenolide M (577) & 7.6 & 15.9 \\
juncenolide N (578) & 6.7 & 29.0 \\
juncenolide O (579) & 27.6 & 35.9 \\
briarenolide J (580) & 14.98 & 9.96 \\
genistein & 65.0 & 51.6 \\
\hline
\end{tabular}

a $\%$ inhibition at $10 \mu \mathrm{g} / \mathrm{mL}$ concentration.

Marine bacteria have yielded some antiinflammatory compounds, such as Streptomyces sp. CNS284 which produces 2-bromo-1-hydroxyphenazine (581) (Figure 112), which has some activity in the $\mathrm{NF}-\kappa \mathrm{B}$-luciferase assay $\left(\mathrm{IC}_{50} 73 \mu \mathrm{M}\right)$ [203]. Several synthetic analogues are more active than $\mathbf{5 8 1}$ and show potent inhibition of $i$-NOS expression and display chemoprevention, QR1 (quinone reductase 1) induction and QR2 (quinone reductase 2) inhibition. The two novel phenazines, $\mathbf{5 8 2}$ and 583, were characterized from the same Streptomyces sp. CNS284 along with the known lavanducyanin (584) (Figure 112) [204]. All three phenazines inhibit TNF- $\alpha$-induced NF- $\kappa B$ activity (IC50 4.1, 24.2, and $16.3 \mu \mathrm{M}$, respectively), and LPS-induced NO production ( $\mathrm{IC}_{50}>48.6,15.1$, and $8.0 \mu \mathrm{M}$, respectively). The blocking of $\mathrm{PGE}_{2}$ production was even more efficient ( $\mathrm{IC}_{50} 7.5,0.89$, and $0.63 \mu \mathrm{M}$, respectively). This study also shows that lavanducyanin inhibits the activity of COX-1 and COX-2, in addition to the production of $\mathrm{NO}$ and $\mathrm{PGE}_{2}$.<smiles>CCCCC(C)(C)CCn1c2ccc(Br)c(=O)c-2nc2ccccc21</smiles><smiles>CCCCCn1c2ccc(Br)c(=O)c-2nc2ccccc21</smiles><smiles>CC1=C(Cn2c3cccc(=O)c-3nc3ccccc32)CCC(C)(C)C1</smiles>
lavanducyanin (584)

Figure 112. Structures of phenazines (581-584) from Streptomyces sp. CNS284 [203,204]. 


\section{Enzymatic and Molecular Activity}

Overshadowed by the biological effects presented in the previous sections are molecular interactions between the marine natural products and the target molecules (enzymes, peptides, and other small biological molecules) that are the root cause of these effects. A review of the targeting of marine natural products to cytoskeletal proteins has appeared [205].

Several marine brominated natural products are protein kinase inhibitors. Purpuroines A (59) and D (62) (Figure 11) are selective inhibitors of the kinase LCK (lymphocyte-specific protein tyrosine kinase) with $\mathrm{IC}_{50} 2.35$ and $0.94 \mu \mathrm{g} / \mathrm{mL}$, respectively. Purpuroine D is inhibitory towards PLK1 (serine/threonine-protein kinase) with $\mathrm{IC}_{50} 0.94 \mu \mathrm{g} / \mathrm{mL}$. For comparison, staurosporine shows $\mathrm{IC}_{50}$ 3.73 and $0.92 \mu \mathrm{g} / \mathrm{mL}$ for LCK and PLK1, respectively. All of the purpuroines are weak inhibitors to CDK2 (cyclin-dependent kinase 2) ( $\mathrm{IC}_{50}>50 \mu \mathrm{g} / \mathrm{mL}$ ) [46]. The study of the massadines (Figure 12) re-established that the known debromohymenialdisine and hymenialdisine are nanomolar kinase inhibitors of CDK5/P25 (cyclin-dependent kinase 5), CD1 $\delta$ (casein kinase 1), and GSK3 $\beta$ (glycogen synthase kinase $3 \beta$ ): $\mathrm{IC}_{50} 0.4,0.1$, and $0.2 \mu \mathrm{M}$, respectively, for debromohymenialdisine, and $\mathrm{IC}_{50}$ $0.16,0.03$, and $0.07 \mu \mathrm{M}$, respectively, for hymenialdisine [47]. The novel sesquibastadin 1 (367) and bastadin 3 (Figure 71) are strong inhibitors of at least 22 protein kinases (IC50 $0.1-6.5 \mu \mathrm{M}$ ). For example sesquibastadin 1 causes potent inhibition of the receptor tyrosine kinases EGF-R and VEGF-R2 (both $\mathrm{IC}_{50} 0.6 \mu \mathrm{M}$ ), and of T1E2 $\left(\mathrm{IC}_{50} 0.6 \mu \mathrm{M}\right.$ ). Bastadin 3 is a potent inhibitor of Aurora A and $\mathrm{B}$ ( $\mathrm{IC}_{50} 0.1$ and $0.5 \mu \mathrm{M}$, respectively). This bastadin inhibits all of the examined kinases at submicromolar activity. The other bastadins $6,7,11$, and 16 are either inactive or much less active, exactly the opposite to their cell proliferation inhibitory activity (vide supra) [139]. A study of the known ageladine A, and synthetic analogues, against a battery of kinases shows that ageladine A has modest activity towards the tyrosine kinase DYRK1A and Pim 1 [206]. The Indonesian sponges Stylissa massa and Stylissa flabelliformis yielded 25 bromopyrroles, including the new dispacamide E (585) and 586 (Figure 113) [207]. All isolated compounds were assayed against these protein kinases: DYRK1A, CDK5, GSK-3, CLK-1, CK-1, CDK1, CDK2/A, CDK9/cyclin T, and Plasmodium falciparum glycogen synthase kinase-3 (PfGSK-3). Dispacamide E is particularly active against GSK-3, DYRK1A and CK-1 (IC50 2.1, 6.2, and $4.9 \mu \mathrm{M}$, respectively). The known hymenine and some hymenialdisine derivatives are very active against PfGSK-3 with $\mathrm{IC}_{50}$ in the nanomolar range [207]. The red alga Laurencia similis from the Hainan coast, China, has afforded five new polybrominated compounds, 587-591 (Figure 114) [208]. The brominated $N$-bromo-2-naphthylamines 588-590 are remarkably unique structures, unlike the brominated diphenyl ether $\mathbf{5 8 7}$ and benzophenone 591, for which many examples are known. Metabolites 587 and 591 are inhibitory towards PTP1B (protein tyrosine phosphatase B) with $\mathrm{IC}_{50} 2.97$ and $2.66 \mu \mathrm{M}$, respectively. The Yesinia outer protein (YopE), which is also a protein tyrosine phosphatase, is inhibited by pseudoceramines B (52) and D (54) (Figure 9), with $\mathrm{IC}_{50} 19$ and $6 \mu \mathrm{M}$, respectively [44]. This enzyme is essential for bacterial virulence of the Gram-negative Yersinia spp. 


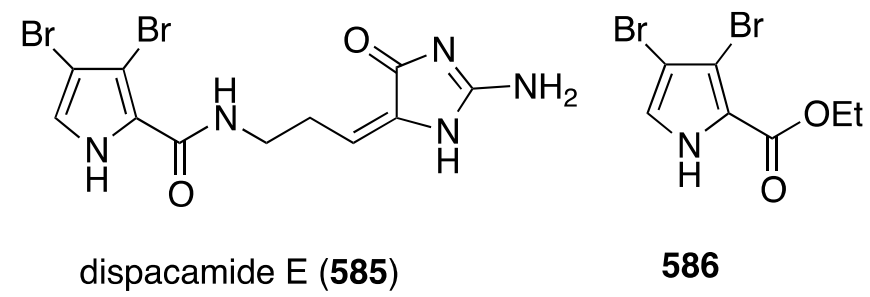

Figure 113. Structures of dispacamide E (585) and pyrrole $\mathbf{5 8 6}$ from the sponges Stylissa massa and Stylissa flabelliformis [207].<smiles>Cc1cc(C)c(Oc2cc(Br)cc(Br)c2Br)c(Br)c1</smiles>

587<smiles>COc1cc(C(=O)c2c(Br)c(Br)c(OC)c(OC)c2Br)c(Br)c(Br)c1OC</smiles>

591<smiles></smiles>

$588\left(R^{1}=B r, R^{2}=R^{3}=H\right)$ $589\left(R^{3}=B r, R^{1}=R^{2}=H\right)$ $590\left(R^{2}=B r, R^{1}=R^{3}=H\right)$

Figure 114. Structures of polybromides 587-591 from the red alga Laurencia similis [208].

The known helicusin A which was isolated from the fungus Bartalina robillardoides strain LF550 along with three new chloroazaphilones (Figure 27), shows inhibition of acetylcholinesterase (IC50 $2.1 \mu \mathrm{M}$ ) (the positive control hyperzine has $\mathrm{IC}_{50}<0.1 \mu \mathrm{M}$ ). In this study the known deacetylsclerotiorin inhibits phosphodiesterase 4 (IC $502.79 \mu \mathrm{M}$ ), as does isochromophilone XI (164), albeit weaker (IC50 $8.30 \mu \mathrm{M}$ ). (The positive control rolipam has $0.75 \mu \mathrm{M})$ [71]. The new pulmonarins A (592) and B (593) (Figure 115), isolated from the clonial ascidian Synoicum pulmonaria living on the coast of Tromsø, Norway, are reversible, noncompetitive inhibitors of acetylcholinesterase; $\mathrm{K}_{\mathrm{i}}=90 \mu \mathrm{M}$ and $20 \mu \mathrm{M}$, respectively. Relative to 593, the Calabar bean alkaloid physostigmine has $\mathrm{K}_{\mathrm{i}}=30 \mathrm{nM}$ [209]. The South China Sea sponge Xestospongia testudinaria has yielded the novel mutafuran (594) (Figure 115) along with three known bromine-containing polyacetylenes [210]. Mutafuran shows significant acetylcholinesterase activity $\left(\mathrm{IC}_{50} 0.64 \mu \mathrm{M}\right)$. The positive control tacrine, which is used to treat early stage Alzheimer's disease, has $\mathrm{IC}_{50} 0.41 \mu \mathrm{M}$.<smiles>COc1c(Br)cc(C(=O)OCC[N+](C)(C)C)cc1Br</smiles>

pulmonarin A (592)<smiles>COc1c(Br)cc(CC(=O)NCCCCC[N+](C)(C)C)cc1Br</smiles>

pulmonarin B (593)<smiles>COC(/C=C/CCCCCC=C(Br)Br)C1CCCO1</smiles>

mutafuran $\mathrm{H}(594)$

Figure 115. Structures of pulmonarins A (592) and B (593) from the ascidian Synoicum pulmonaria [209] and mutafuran H (594) from the sponge Xestospongia testudinaria [210].

Several marine organohalogens discovered in the timeframe of this survey are protease inhibitors. The Ianthella sp. sponge metabolites dictyodendrin F, H, I, and J (Figure 14) are potent inhibitors of BACE 1 ( $\beta$-secretase 1) with IC 50 values of 1.0-2.0 $\mu \mathrm{M})$. Only dictyodendrin G (75) is inactive [49]. The known cyanobacterium fischerindole hapalosin inhibits the 20 s proteasome $\left(\mathrm{IC}_{50} 12 \mu \mathrm{M}\right)$, whereas 
the other fischerindoles isolated in this study (Figure 92) are inactive [173]. Extensive studies of the cyanobacteria Microcystis aeruginosa and Microcystis spp. in Israel and India have revealed several novel aeruginosins. These are aeruginosin GE686 (595), GE766 (596), GE730 (597), GE810 (598), GE642 (599) [211], IN608 (600), IN652 (601) [212], LH650A (602), LH650B (603), LH606 (604), and the nonchlorinated microviridin LH1667 [213] (Figure 116). Several known analogues were also isolated from these blooms. The aeruginosins are inhibitors of the serine proteolytic enzymes trypsin and thrombin. The trypsin inhibitory activities $\left(\mathrm{IC}_{50} \mu \mathrm{M}\right)$ are best realized for GE686 (595), 3.2; GE730 (597), 2.3; IN608 (600), 4.3; IN652 (601), 4.1; and LH606 (604), 18.5. The thrombin inhibitory activities $\left(\mathrm{IC}_{50} \mu \mathrm{M}\right)$ are best seen for GE686 (595), 12.8; GE730 (597), 12.9; LH650A (602), 1.8; LH650B (603), 1.8; and LH606 (604) 2.5. Microviridin inhibits chymotrypsin, IC $502.8 \mu \mathrm{M}$ [211-213].

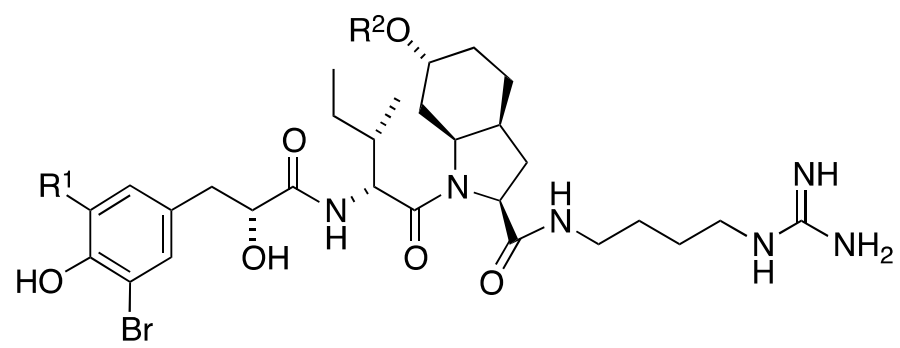

$$
\begin{aligned}
& \text { aeruginosin GE686 }\left(R^{1}=\mathrm{Cl}, \mathrm{R}^{2}=\mathrm{H}\right)(\mathbf{5 9 5}) \\
& \text { aeruginosin GE766 }\left(\mathrm{R}^{1}=\mathrm{Cl}, \mathrm{R}^{2}=\mathrm{SO}_{3} \mathrm{H}\right)(\mathbf{5 9 6}) \\
& \text { aeruginosin GE730 }\left(\mathrm{R}^{1}=\mathrm{Br}, \mathrm{R}^{2}=\mathrm{H}\right)(\mathbf{5 9 7}) \\
& \text { aeruginosin GE810 }\left(\mathrm{R}^{1}=\mathrm{Br}, \mathrm{R}^{2}=\mathrm{SO}_{3} \mathrm{H}\right)(\mathbf{5 9 8})
\end{aligned}
$$<smiles>[R]c1cc(C[C@H](O)C(=O)N[C@@H](CC(C)(C)C)C(=O)N2[C@H](C(=O)NCCCCNC(=N)N)C[C@@H]3CC[C@H](O)C[C@H]32)cc([R2])c1O</smiles>

$$
\begin{aligned}
& \text { aeruginosin GE642 }\left(R^{1}=R^{2}=C l\right)(599) \\
& \text { aeruginosin GE608 }\left(R^{1}=C l, R^{2}=H\right)(600)
\end{aligned}
$$$$
\text { aeruginosin GE652 }\left(R^{1}=\mathrm{Br}, \mathrm{R}^{2}=\mathrm{H}\right)(\mathbf{6 0 1})
$$<smiles>[R]C1[C@H](NC(=O)[C@@H]2C[C@@H]3CC[C@@H](O)C[C@H]3N2C(=O)[C@H](CC(C)(C)C)NC(=O)[C@H](O)Cc2ccc(O)c(Cl)c2)CCCN1C(=N)N</smiles><smiles>CC(C)(C)C[C@H](NC(=O)[C@H](O)Cc1ccc(O)c(Cl)c1)C(=O)N1C2C[C@H](O)CC[C@H]2C[C@H]1C(=O)N[C@H]1CCCN1C(=N)N</smiles>

aeruginosin LH606 (604)

Figure 116. Structures of aeruginosins 595-604 from the cyanobacteria Microcystis aeruginosa and Microcystis spp. [211-213]. 
<smiles>[R]c1cc(/C=C/C(=O)NCCCC[C@H](N)C(=O)O)cc(Br)c1OC</smiles>

aplysinellamide $A(R=H)(605)$ aplysinellamide $B(R=B r)(606)$<smiles>COc1ccc(/C=C/C(=O)NCCCCC(=O)O)cc1Br</smiles>

aplysinellamide C (607)<smiles>COc1c(Br)cc(/C=C(\O)C(=O)O)cc1Br</smiles>

610<smiles>CN(C)CCCOc1c(Br)cc(CC[N+]([O-])([O-])O)cc1Br</smiles>

aplysamine-1- $\mathrm{N}$-oxide (608)

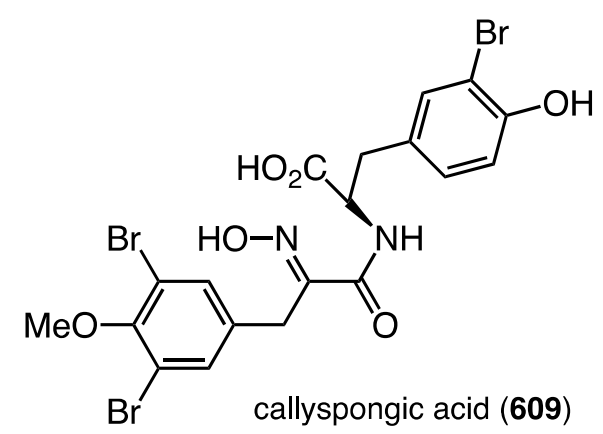

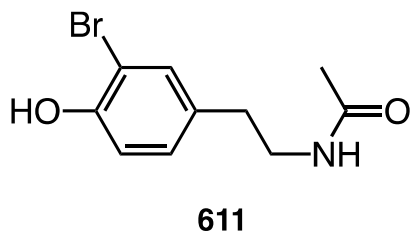

Figure 117. Structures of bromotyrosines 605-611 from the sponges Aplysinella sp. and Callyspongia sp. [214,215].

Some marine sponge metabolites increase the production of ApoE (apoliproprotein E), an important enzyme that mediates cholesterol metabolism, which has implication in the treatment of Alzheimer's disease. The Great Barrier Reef, Australia, sponge Aplysinella sp. has afforded three new aplysinellamides A-D (605-607) and aplysamine-1- $N$-oxide (608) (Figure 117) along with six known analogues. Amongst the latter, aplysamine-1 displays ApoE-modulating activity by increasing by 2-fold the secretion of ApoE from human astrocytoma cells at a concentration of $30 \mu \mathrm{M}$ [214]. Likewise, the Australian sponge Callyspongia sp. has yielded the new bromotyrosines 609-611, along with ten known compounds (Figure 117). Of these, $\mathbf{6 1 0}$ shows weak ability to increase ApoE from human astrocytoma cells (CCF-STTG1) at a concentration of $40 \mu \mathrm{M}$ [215].

The sponge Xestospongia testudinaria has yielded five new brominated fatty acids, 612-616 (Figure 118), which include testufuran A (612), similar to mutafuran H (594) (Figure 115) isolated from the same sponge. An additional 11 known brominated acetylenic acids were also characterized. Most of these 16 bromo carboxylic acids stimulated the secretion of the protein hormone adiponectin, which regulates glucose levels and fatty acid breakdown, from differentiated ST-13 preadipocytes. These compounds do not exhibit agonistic activity against PPAR- $\gamma$ (the peroxisome proliferator-activated receptor) [216].

The ascidian Herdmania momus has yielded seven new herdmanines E-K (617-623) (Figure 119), some of which demonstrate significant PPAR- $\gamma$ activation in Ac2F rat liver cells. The active examples are I (621) and K (623). For example, the latter herdmanine $K$ exhibits strong PPAR- $\gamma$ activation at 1 and $10 \mu \mathrm{g} / \mathrm{mL}$ concentrations, with greater potency than the antidiabetic drug rosiglitazone. The known (-)-leptoclinidamine B was also isolated from the ascidian and is only slightly less active than 623 [217]. 


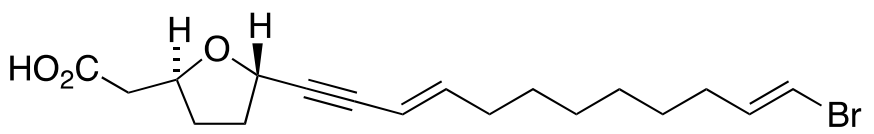

testufuran A (612)
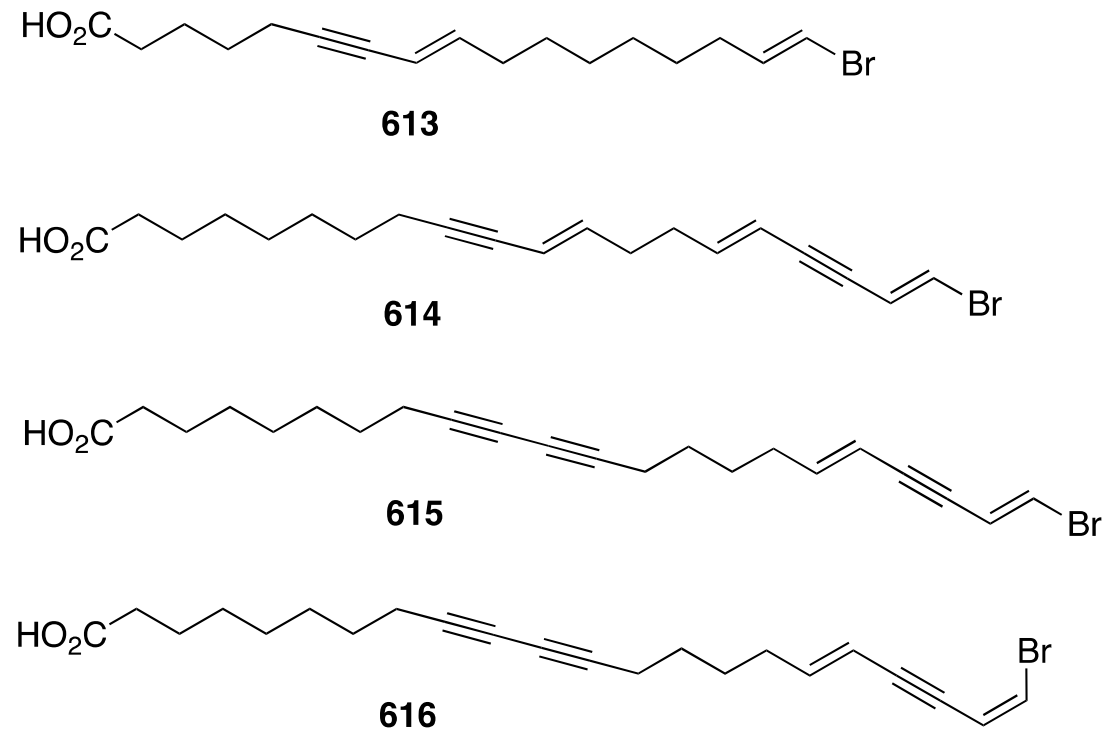

Figure 118. Structures of bromo carboxylic acids 612-616 from the sponge Xestospongia testudinaria [216].<smiles>N=C(N)NCCCC(NC(=O)c1ccc(OC(=O)c2c[nH]c3cc(Br)c(O)cc23)cc1)C(=O)O</smiles>
herdmanine $E(617)$<smiles>[R]c1cc(C(=O)N[C@@H](CCCNC(=N)N)C(=O)O)ccc1O</smiles>

herdmanine $\mathrm{F}(\mathrm{R}=\mathrm{Br})(\mathbf{6 1 8})$ herdmanine $\mathrm{G}(\mathrm{R}=\mathrm{OMe})(\mathbf{6 1 9})$ herdmanine $H(R=H)(620)$<smiles>Cn1cc(C(=O)NCCCCC(N)C(=O)O)c2ccccc21</smiles>

herdmanine $\mathrm{J}(\mathbf{6 2 2})$<smiles>O=C(N[C@@H](Cc1c[nH]cn1)C(=O)O)C(=O)c1c[nH]c2cc(O)ccc12</smiles>

herdmanine $\mathrm{K}(623)$

Figure 119. Structures of herdmanines E-K (617-623) from the ascidian Herdmania momus [217]. 

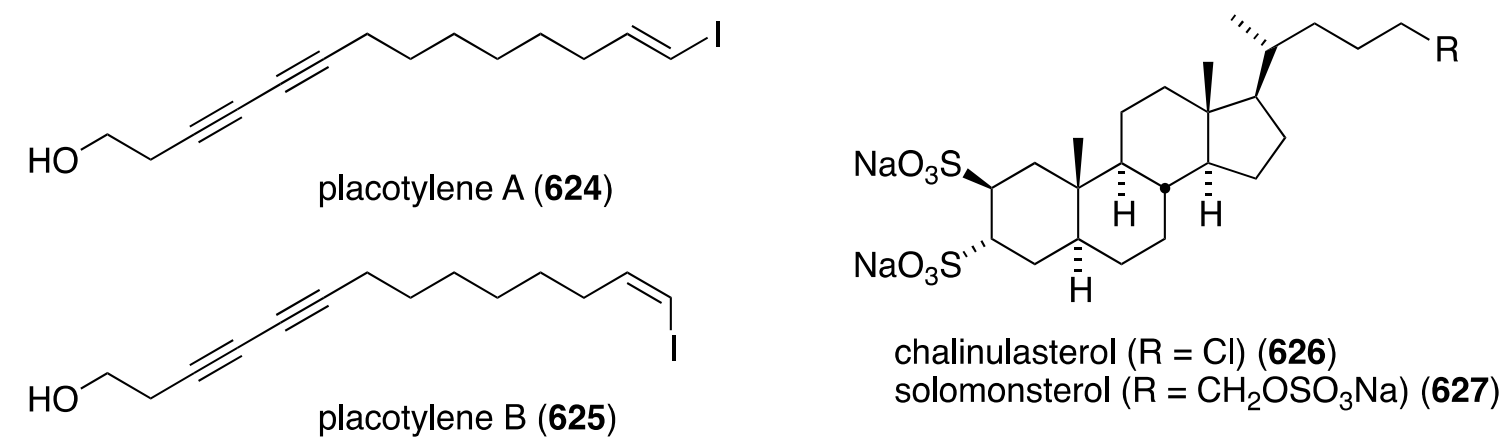

Figure 120. Structures of placotylenes A (624) and B (625) from the sponge Placospongia sp. [218] and chalinulasterol (626) from the sponge Chalinula molitba [219].

The two rare iodinated polyacetylenes, placotylenes A (624) and B (625), were characterized in the Korean sponge Placospongia sp. (Figure 120). Placotylene A inhibits osteoclast differentiation of bone marrow-derived macrophages, perhaps by decreasing the expression of RANKL (receptor activator of nuclear factor- $\kappa \mathrm{B}$ ligand). This marine polyacetylene could represent a lead compound for osteoporosis treatment [218]. The Caribbean sponge Chalinula molitba has afforded the novel chlorinated sterol disulfate, chalinulasterol (626) (Figure 120). Despite the resemblance of chalinulasterol to the known PXR (pregnane X receptor) agonist solomonsterol A (627), no activity is observed for the former sterol. This important receptor regulates expression of drug metabolizing and detoxifying enzymes [219].

Two sets of metabolites from the ascidian Synoicum sp. exhibit inhibition of the peptidase-type proteins sortase A and isocitrate lyase, two enzymes that have important functions in the virulence and survival of pathogenic bacteria. Thus, of the eudistomins cited earlier (Figure 23), $\mathrm{Y}_{4}$ (134) and $\mathrm{Y}_{5}$ (135) show modest activity toward sortase A (SrtA) (IC50 163.2 and $146.4 \mu \mathrm{M}$, respectively), whereas $\mathrm{Y}_{2}$ (132) shows $\mathrm{IC}_{50} 50.2 \mu \mathrm{M}$ against isocitrate lyase (ICL) [65]. Of the brominated aromatic furanones examined (Figure 24), cardiolide E (138) inhibits SrtA ( $\mathrm{IC}_{50} 78.8 \mu \mathrm{M}$ ), and cardiolides E (138) and I (142) show IC 508.9 and $10.8 \mu \mathrm{M}$, respectively, for SrtA [67]. These Synoicum metabolites also inhibit the enzyme $\mathrm{Na}^{+} / \mathrm{K}^{+}$-ATPase (sodium-potassium adenosine triphosphatase) as follows: $\mathrm{Y}_{4}$ (134), $\mathrm{Y}_{6}$ (136), $\mathrm{Y}_{7}$ (137), cardiolide $\mathrm{E}$ (138), and cardiolide I (142) give these values: 7.5, 10.1, 11.3, 2.5 , and $5.0 \mu \mathrm{M}$, respectively $[65,67]$. This enzyme is a sodium-potassium pump with several functions.

A combined Curacao and Papua New Guinea collection of cyanobacteria has yielded five new vinylchloride metabolites, janthielamide A (628), kimbeamides A-C (629-631), and kimbelactone A (632) (Figure 121). Janthielamide A came from the collection at Jan Thiel Bay in Curacao, and the latter four metabolites came from the collection at Kimbe Bay, New Britain, Papua New Guinea. Janthielamide A (628) exhibits $\mathrm{Na}^{+}$channel blocking in murine Neuro-2a cells ( $\mathrm{IC}_{50} 11.5 \mu \mathrm{M}$ ), and also antagonizes induced $\mathrm{Na}^{+}$influx in neurons ( $\mathrm{IC}_{50} 5.2 \mu \mathrm{M}$ ). Kimbeamide A (629) displays similar $\mathrm{Na}^{+}$blocking activity at a concentration of $20 \mu \mathrm{g} / \mathrm{mL}$, but it, along with the 630-632, undergoes oxidative decomposition [220].

The new isomalbrancheamide B (633), along with three known analogues, was isolated from the fungus Malbranchea aurantiaca (Figure 122). Isomalbrancheamide B (633) and the known malbrancheamide (634) and malbrancheamide B (635) are classical CaM (calmodulin) inhibitors, whereas the nonchlorinated premalbrancheamide (636) is not. Malbrancheamide (634) is the most 
active, and it binds to the same hydrophobic pocket as the antipsychotics chlorpromazine and trifluoperazine, two classical CaM inhibitors [221].<smiles>CC(C)=CC(=O)NCC[C@H](C)/C=C/C[C@H](C)/C=C/C=C\Cl</smiles>

janthielamide $\mathrm{A}(628)$<smiles>COC1=CC(=O)OC(CC/C=C/C=C\C(C)/C=C/C(C)=C/Cl)C1</smiles>

kimbelactone A (632)<smiles>CC(=CCl)CC=CC=CC(=O)NC(C)C=CCCC=CCl</smiles>

kimbeamide $\mathrm{A}\left(4 E, 2^{\prime} Z\right)(629)$

kimbeamide $B(4 Z, 2 ' Z)(630)$

kimbeamide $C\left(4 E, 2^{\prime} E\right)(631)$

Figure 121. Structures of janthielamide A (628), kimbeamides $A-C$ (629-631), and kimbelactone A (632) from cyanobacteria [220].

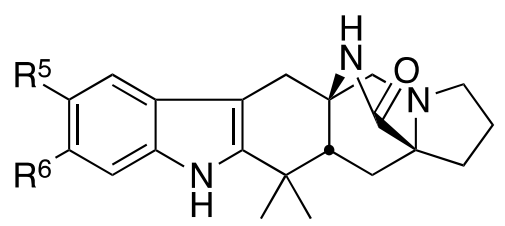

$$
\begin{aligned}
& 633\left(R^{5}=C l, R^{6}=H\right) \text { (malbrancheamide) } \\
& 634\left(R^{5}=R^{6}=C l\right)(\text { malbrancheamide) } \\
& 635\left(R^{5}=H, R^{6}=C l\right) \text { (malbrancheamide) } \\
& 636\left(R^{5}=R^{6}=H\right)(\text { malbrancheamide) }
\end{aligned}
$$

Figure 122. Structures of malbrancheamides 633-636 from the fungus Malbranchea aurantiaca [221].

The previously cited 5,6-dibromo-L-hypaphorine (558) (Figure 107) from the sponge Hyrtios sp. is a weak inhibitor of bee venom phospholipase $\mathrm{A}_{2}\left(\mathrm{PLA}_{2}\right)$. Relative to the positive control, manoalide ( $\left.\mathrm{IC}_{50} 0.5 \mu \mathrm{M}\right), 558$ has $\mathrm{IC}_{50} 0.20 \mathrm{mM}$ [195]. The red alga Laurencia okamurai has yielded the new chamigrane, okamurene $\mathrm{E}$ (637), and the new $\mathrm{C}_{12}$-acetogenin, okamuragenin (638) (Figure 123), along with the known okamurenes $\mathrm{A}-\mathrm{D}$ and nine known sesquiterpenes and four known $\mathrm{C}_{15}$-acetogenins. All of these compounds were evaluated for toxicity against brine shrimp (Artemia salina). Of all compounds, only 7-hydroxylaurene (639) expressed lethal toxicity with LD50 $1.8 \mu \mathrm{M}$ [222].<smiles>CC1=CC[C@@H](Br)C(C)(C)C12C=CC(C)(O)C=C2</smiles>

okamurene $\mathrm{E}(637)$<smiles>CCC(Br)[C@H]1C[C@@H](Br)[C@H]2CC[C@@H]1O[C@@H]2CC=O</smiles>

okamuragenin (638)<smiles>C=C1CCC(C)(c2ccc(C)cc2O)[C@H]1C</smiles>

7-hydroxylaurene (639)

Figure 123. Structures of okamurene E (637) and okamuragenin (638) from the red alga Laurencia okamurai, and 7-hydroxylaurene (639) [222]. 
The marine-derived fungus Aspergillus sp. SCSGAF0093 produces nine mycotoxins, four of which are new, aluminiumneoaspergillin (640), zirconiumneoaspergillin (641), aspergilliamide (642), and ochratoxin A $n$-butyl ester (643) (Figure 124). This is the first report of marine-based ochratoxins (ochratoxin and the methyl ester were also isolated), and the first discovery of a zirconium complex (641) in nature [223]. All nine compounds exhibit some toxicity to brine shrimp. The most toxic compounds in this assay are $\mathbf{6 4 3}$, ochratoxin A, and ochratoxin A methyl ester, with $\mathrm{IC}_{50} 4.14,13.74$, and $2.59 \mu \mathrm{M}$, respectively.

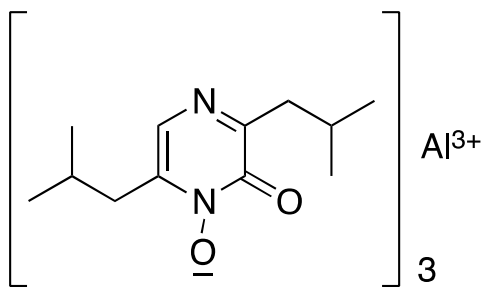

640<smiles>CC(C)CC(=O)NC(=O)/C(CC(C)C)=N\O</smiles>

642<smiles>CC(C)Cc1ncc(CC(C)C)n([O-])c1=O</smiles>

641<smiles>C[C@H]1Cc2c(Cl)cc(C(=O)N[C@@H](Cc3ccccc3)C(=O)OCc3ccccc3)c(O)c2C(=O)O1</smiles>

Figure 124. Structures of mycotoxins 640-643 from the fungus Aspergillus sp. SCSGAF0093 [223].

The innocent-looking, but ominous cone snails (genus Conus) comprise about 700 species and are widely distributed in the world's oceans [224]. It is estimated that these cone snails contain more than 50,000 distinct toxins, since the venom in each Conus species consists of 40-200 individual peptides with a unique biological action [225-227]. Many of these Conus sp. peptides contain 6-bromotryptophan [3], the function of which has been suggested to block proteolytic degradation since the large bromine makes the peptide a poor fit for docking in the active site of chymotrypsin [228]. Recent studies have established the binding site of $\alpha$-conotoxin Vc1.1 from Conus victoria on the nicotinic $\alpha 9 \alpha 10$ acetylcholine receptor, making this toxin a potential novel treatment for neuropathic pain [229]. A similar $\alpha-4 / 6$-conotoxin TxID has been identified in Conus textile. It also blocks nicotinic acetylcholine receptors [230]. The conopeptide MVIIA (Ziconotide; Prialt) was approved by the U.S. FDA in 2004 for the treatment of severe pain.

\section{Conclusions}

Marine organisms possess an astonishing array of biological activities! The chemical compounds they produce proffer future medicinal developments in a multitude of human diseases. Of these compounds, organohalogen natural products frequently display the highest level of biological activity. The unceasing developments in aquatic exploration, organism collection, compound isolation and 
identification, and biological assays guarantee that new marine natural products are awaiting discovery, biological evaluation, and possible benefit to mankind.

\section{Conflicts of Interest}

The author declares no conflict of interest.

\section{References}

1. Fowden, L. The occurrence and metabolism of carbon-halogen compounds. Proc. R. Soc. B 1968, 171, 5-18.

2. Gribble, G.W. Naturally occurring organohalogen compounds-A comprehensive survey. Prog. Chem. Org. Nat. Prod. 1996, 68, 1-496.

3. Gribble, G.W. Naturally occurring organohalogen compounds-A comprehensive update. Prog. Chem. Org. Nat. Prod. 2010, 91, 1-613.

4. Gribble, G.W. Chapter 1-Occurrence of halogenated alkaloids. In The Alkaloids: Chemistry and Biology; Knölker, H.-J., Ed.; Academic Press: Amsterdam, The Netherlands, 2012; Volume 71, pp. 1-165.

5. Gribble, G.W. Recently discovered naturally occurring heterocyclic organohalogen compounds. Heterocycles 2012, 84, 157-207.

6. Gribble, G.W. The published total number of all naturally occurring organohalogens through the year 2007 is 4714. Unpublished work, 2015.

7. Blunt, J.W.; Copp, B.R.; Keyzers, R.A.; Munro, M.H.G.; Prinsep, M.R. Marine natural products. Nat. Prod. Rep. 2012, 29, 144-222.

8. Blunt, J.W.; Copp, B.R.; Keyzers, R.A.; Munro, M.H.G.; Prinsep, M.R. Marine natural products. Nat. Prod. Rep. 2013, 30, 237-323.

9. Blunt, J.W.; Copp, B.R.; Keyzers, R.A.; Munro, M.H.G.; Prinsep, M.R. Marine natural products. Nat. Prod. Rep. 2014, 31, 160-258.

10. Blunt, J.W.; Copp, B.R.; Keyzers, R.A.; Munro, M.H.G.; Prinsep, M.R. Marine natural products. Nat. Prod. Rep. 2015, 32, 116-211.

11. La Barre, S.; Potin, P.; Leblanc, C.; Delage, L. The halogenated metabolism of brown algae (Phaeophyta), its biological importance and its environmental significance. Mar. Drugs 2010, 8 , 988-1010.

12. Wang, B.-G.; Gloer, J.B.; Ji, N.-Y.; Zhao, J.-C. Halogenated organic molecules of Rhodomelaceae origin: Chemistry and biology. Chem. Rev. 2013, 113, 3632-3685.

13. Osako, K.; Teixeira, V.L. Natural products from marine algae of the genus Osmundaria (Rhodophyceae, Ceramiales). Nat. Prod. Commun. 2013, 8, 533-538.

14. Lira, N.S.; Montes, R.C.; Tavares, J.F.; da Silva, M.S.; da Cunha, E.V.L.; de Athayde-Filho, P.F.; Rodrigues, L.C.; da Silva Dias, C.; Barbosa-Filho, J.M. Brominated compounds from marine sponges of the genus Aplysina and a compilation of their ${ }^{13} \mathrm{C}$ NMR spectral data. Mar. Drugs 2011, 9, 2316-2368. 
15. Van Soest, R.W.M.; Boury-Esnault, N.; Vacelet, J.; Dohrmann, M.; Erpenbeck, D.; de Voogd, N.J.; Santodomingo, N.; Vanhoorne, B.; Kelly, M.; Hooper, J.N.A. Global diversity of sponges (Porifera). PLos ONE 2012, 7, e35105.

16. Noro, J.C.; Kalaitzis, J.A.; Neilan, B.A. Bioactive natural products from Papua New Guinea marine sponges. Chem. Biodivers. 2012, 9, 2077-2095.

17. Pauletti, P.M.; Cintra, L.S.; Braguine, C.G.; da Silva Filho, A.A.; Andrade e Silva, M.L.; Cunha, W.R.; Januário, A.H. Halogenated indole alkaloids from marine invertebrates. Mar. Drugs 2010, 8, 1526-1549.

18. Benkendorff, K. Natural product research in the Australian marine invertebrate Dicathais orbita. Mar. Drugs 2013, 11, 1370-1398.

19. Bingham, J.-P.; Mitsunaga, E.; Bergeron, Z.L. Drugs from slugs-Past, present and future perspectives of $\omega$-conotoxin research. Chem. Biol. Interact. 2010, 183, 1-18.

20. Sheu, J.-H.; Chen, Y.-H.; Chen, Y.-H.; Su, Y.-D.; Chang, Y.-C.; Su, J.-H.; Weng, C.-F.; Lee, C.-H.; Fang, L.-S.; Wang, W.-H.; et al. Briarane diterpenoids isolated from gorgonian corals between 2011 and 2013. Mar. Drugs 2014, 12, 2164-2181.

21. Asakawa, Y.; Ludwiczuk, A.; Nagashima, F. Phytochemical and biological studies of bryophytes. Phytochemistry 2013, 91, 52-80.

22. Rateb, M.E.; Ebel, R. Secondary metabolites of fungi from marine habitats. Nat. Prod. Rep. 2011, 28, 290-344.

23. Beck, C.; Knoop, H.; Axmann, I.M.; Steuer, R. The diversity of cyanobacterial metabolism: Genome analysis of multiple phototrophic microorganisms. BMC Genomics 2012, 13, 56-72.

24. Rahman, H.; Austin, B.; Mitchell, W.J.; Morris, P.C.; Jamieson, D.J.; Adams, D.R.; Spragg, A.M.; Schweizer, M. Novel anti-infective compounds from marine bacteria. Mar. Drugs 2010, 8, 498-518.

25. Schnermann, M.J.; Shenvi, R.A. Syntheses and biological studies of marine terpenoids derived from inorganic cyanide. Nat. Prod. Rep. 2015, 32, 543-577.

26. Lutz, R.A.; Falkowski, P.G. A dive to Challenger Deep. Science 2012, 336, 301-302.

27. Brown, D.G.; Lister, T.; May-Dracka, T.L. New natural products as new leads for antibacterial drug discovery. Bioorg. Med. Chem. Lett. 2014, 24, 413-418.

28. Fletcher, M.H.; Jennings, M.C.; Wuest, W.M. Draining the moat: Disrupting bacterial biofilms with natural products. Tetrahedron 2014, 70, 6373-6383.

29. Stowe, S.D.; Richards, J.J.; Tucker, A.T.; Thompson, R.; Melander, C.; Cavanagh, J. Anti-biofilm compounds derived from marine sponges. Mar. Drugs 2011, 9, 2010-2035.

30. Li, C.; La, M.-P.; Sun, P.; Kurtan, T.; Mandi, A.; Tang, H.; Liu, B.-S.; Yi, Y.-H.; Li, L.; Zhang, W. Bioactive (3Z,5E)-11,20-epoxybriara-3,5-dien-7,18-olide diterpenoids from the South China Sea gorgonian Dichotella gemmacea. Mar. Drugs 2011, 9, 1403-1418.

31. Li, C.; La, M.-P.; Tang, H.; Pan, W.-H.; Sun, P.; Krohn, K.; Yi, Y.-H.; Li, L.; Zhang, W. Bioactive briarane diterpenoids from the South China Sea gorgonian Dichotella gemmacea. Bioorg. Med. Chem. Lett. 2012, 22, 4368-4372.

32. Sun, J.-F.; Huang, H.; Chai, X.-Y.; Yang, X.-W.; Meng, L.; Huang, C.-G.; Zhou, X.-F.; Yang, B.; Hu, J.; Chen, X.-Q.; et al. Dichotellides A-E, five new iodine-containing briarane type diterpenoids from Dichotella gemmacea. Tetrahedron 2011, 67, 1245-1250. 
33. Li, C.; La, M.-P.; Li, L.; Li, X.-B.; Tang, H.; Liu, B.-S.; Krohn, K.; Sun, P.; Yi, Y.-H.; Zhang, W. Bioactive 11,20-epoxy-3,5(16)-diene briarane diterpenoids from the South China Sea gorgonian Dichotella gemmacea. J. Nat. Prod. 2011, 74, 1658-1662.

34. Sun, J.-F.; Han, Z.; Zhou, X.-F.; Yang, B.; Lin, X.; Liu, J.; Peng, Y.; Yang, X.-W.; Liu, Y. Antifouling briarane type diterpenoids from South China Sea gorgonians Dichotella gemmacea. Tetrahedron 2013, 69, 871-880.

35. Lei, H.; Sun, J.-F.; Han, Z.; Zhou, X.-F.; Yang, B.; Liu, Y. Fragilisinins A-L, new briarane-type diterpenoids from gorgonian Junceella fragilis. RSC Adv. 2014, 4, 5261-5271.

36. Lai, D.; Li, Y.; Xu, M.; Deng, Z.; van Ofwegen, L.; Qian, P.; Proksch, P.; Lin, W. Sinulariols A-S, 19-oxygenated cembranoids from the Chinese soft coral Sinularia rigida. Tetrahedron 2011, 67, 6018-6029.

37. Shao, C.-L.; Wu, H.-X.; Wang, C.-Y.; Liu, Q.-A.; Xu, Y.; Wei, M.-Y.; Qian, P.-Y.; Gu, Y.-C.; Zheng C.-J.; She, Z.-G.; et al. Potent antifouling resorcylic acid lactones from the gorgonian-derived fungus Cochliobolus lunatus. J. Nat. Prod. 2011, 74, 629-633.

38. Shao, C.-L.; Wu, H.-X.; Wang, C.-Y.; Liu, Q.-A.; Xu, Y.; Wei, M.-Y.; Qian, P.-Y.; Gu, Y.-C.; Zheng C.-J.; She, Z.-G.; et al. Potent antifouling resorcylic acid lactones from the gorgonian-derived fungus Cochliobolus lunatus. J. Nat. Prod. 2011, 74, 629-633; Erratum in 2013, 76, 302.

39. Wei, M.-Y.; Li, D.; Shao, C.-L.; Deng, D.-S.; Wang, C.-Y. ( \pm )-Pestalachloride D, an antibacterial racemate of chlorinated benzophenone derivative from a soft coral-derived fungus Pestalotiopsis sp. Mar. Drugs 2013, 11, 1050-1060.

40. Li, E.; Jiang, L.; Guo, L.; Zhang, H.; Che, Y. Pestalachlorides A-C, antifungal metabolites from the plant endophytic fungus Pestalotiopsis adusta. Bioorg. Med. Chem. 2008, 16, 7894-7899.

41. Núñez-Pons, L.; Carbone, M.; Vázquez, J.; Gavagnin, M.; Avila, C. Lipophilic defenses from alcyonium soft corals of Antarctica. J. Chem. Ecol. 2013, 39, 675-685.

42. Fu, P.; Kong, F.; Wang, Y.; Wang, Y.; Liu, P.; Zuo, G.; Zhu, W. Antibiotic metabolites from the coral-associated actinomycete Streptomyces sp. OUCMDZ-1703. Chin. J. Chem. 2013, 31, 100-104.

43. Pénez, N.; Culioli, G.; Pérez, T.; Briand, J.-F.; Thomas, O.P.; Blache, Y. Antifouling properties of simple indole and purine alkaloids from the Mediterranean gorgonian Paramuricea clavata. J. Nat. Prod. 2011, 74, 2304-2308.

44. Yin, S.; Davis, R.A.; Shelper, T.; Sykes, M.L.; Avery, V.M.; Elofsson, M.; Sundin, C.; Quinn, R.J. Pseudoceramines A-D, new antibacterial bromotyrosine alkaloids from the marine sponge Pseudoceratina sp. Org. Biomol. Chem. 2011, 9, 6755-6760.

45. Salim, A.A.; Khalil, Z.G.; Capon, R.J. Structural and stereochemical investigations into bromotyrosine-derived metabolites from southern Australian marine sponges, Pseudoceratina spp. Tetrahedron 2012, 68, 9802-9807.

46. Shen, S.; Liu, D.; Wei, C.; Proksch, P.; Lin, W. Purpuroines A-J, halogenated alkaloids from the sponge Iotrochota purpurea with antibiotic activity and regulation of tyrosine kinases. Bioorg. Med. Chem. 2012, 20, 6924-6928.

47. Zhang, H.; Khalil, Z.; Conte, M.M.; Plisson, F.; Capon, R.J. A search for kinase inhibitors and antibacterial agents: Bromopyrrolo-2-aminoimidazoles from a deep-water Great Australian Bight sponge, Axinella sp. Tetrahedron Lett. 2012, 53, 3784-3787. 
48. Russell, F.; Harmody, D.; McCarthy, P.J.; Pomponi, S.A.; Wright, A.E. Indolo[3,2-a]carbazoles from a deep-water sponge of the genus Asteropus. J. Nat. Prod. 2013, 76, 1989-1992.

49. Zhang, H.; Conte, M.M.; Khalil, Z.; Huang, X.-C.; Capon, R.J. New dictyodendrins as BACE inhibitors from a southern Australian marine sponge, Ianthella sp. RSC Adv. 2012, 2, 4209-4214.

50. Takahashi, Y.; Tanaka, N.; Kubota, T.; Ishiyama, H.; Shibazaki, A.; Gongoi, T.; Fromont, J.; Kobayashi, J. Heteroaromatic alkaloids, nakijinamines, from a sponge Suberites sp. Tetrahedron 2012, 68, 8545-8550.

51. Takahashi, Y.; Kubota, T.; Shibazaki, A.; Gonoi, T.; Fromont, J.; Kobayashi, J. Nakijinamines C-E, new heteroaromatic alkaloids from the sponge Suberites species. Org. Lett. 2011, 13, 3016-3019.

52. Kubota, T.; Iwai, T.; Takahashi-Nakaguchi, A.; Fromont, J.; Gonoi, T.; Kobayashi, J. Agelasines $\mathrm{O}-\mathrm{U}$, new diterpene alkaloids with a 9-N-methyladenine unit from a marine sponge Agelas sp. Tetrahedron 2012, 68, 9738-9744.

53. Kusama, T.; Tanaka, N.; Takahashi-Nakaguchi, A.; Gonoi, T.; Fromont, J.; Kobayashi, J. Bromopyrrole alkaloids from a marine sponge Agelas sp. Chem. Pharm. Bull. 2014, 62, 499-503.

54. Kusama, T.; Tanaka, N.; Sakai, K.; Gonoi, T.; Fromont, J.; Kashiwada, Y.; Kobayashi, J. Agelamadins A and B, dimeric bromopyrrole alkaloids from a marine sponge Agelas sp. Org. Lett. 2014, 16, 3916-3918.

55. Xu, Y.; Li, N.; Jiao, W.-H.; Wang, R.-P.; Peng, Y.; Qi, S.-H.; Song, S.-J.; Chen, W.-S.; Lin, H.-W. Antifouling and cytotoxic constituents from the South China Sea sponge Acanthella cavernosa. Tetrahedron 2012, 68, 2876-2883.

56. Clive, D.L.J.; Cheng, P. The marinopyrroles. Tetrahedron 2013, 69, 5067-5078.

57. Cheng, C.; Liu, Y.; Song, H.; Pan, L.; Li, J.; Qin, Y.; Li, R. Marinopyrrole derivatives as potential antibiotic agents against methicillin-resistant Staphylococcus aureus (II). Mar. Drugs 2013, 11, 2927-2948.

58. Greff, S.; Zubia, M.; Genta-Jouve, G.; Massi, L.; Perez, T.; Thomas, O.P. Mahorones, highly brominated cyclopentenones from the red alga Asparagopsis taxiformis. J. Nat. Prod. 2014, 77, 1150-1155.

59. Timmers, M.A.; Dias, D.A.; Urban, S. Application of HPLC-NMR in the identification of plocamenone and isoplocamenone from the marine red alga Plocamium angustum. Mar. Drugs 2012, 10, 2089-2102.

60. Li, X.-D.; Ding, W.; Miao, F.-P.; Ji, N.-Y. Halogenated chamigrane sesquiterpenes from Laurencia okamurae. Magn. Reson. Chem. 2012, 50, 174-177.

61. Umezawa, T.; Oguri, Y.; Matsuura, H.; Yamazaki, S.; Suzuki, M.; Yoshimura, E.; Furata, T.; Nogata, Y.; Serisawa, Y.; Matsuyama-Serisawa, K.; et al. Omaezallene from red alga Laurencia sp.: Structure elucidation, total synthesis, and antifouling activity. Angew. Chem. Int. Ed. 2014, 53, 3909-3912.

62. Fang, H.Y.; Chiou, S.-F.; Uvarani, C.; Wen, Z.-H.; Hsu, C.-H.; Wu, Y.-C.; Wang, W.-L.; Liaw, C.-C.; Sheu, J.-H. Cytotoxic, anti-inflammatory, and antibacterial sulfur-containing polybromoindoles from the Formosan red alga Laurencia brongniartii. Bull. Chem. Soc. Jpn. 2014, 87, 1278-1280. 
63. Rodrigues, D.; Alves, C.; Horta, A.; Pinteus, S.; Silva, J.; Culioli, G.; Thomas, O.P.; Pedrosa, R. Antitumor and antimicrobial potential of bromoditerpenes isolated from the red alga, Sphaerococcus coronopifolius. Mar. Drugs 2015, 13, 713-726.

64. Teasdale, M.E.; Shearer, T.L.; Engel, S.; Alexander, T.S.; Fairchild, C.R.; Prudhomme, J.; Torres, M.; le Roch, K.; Aalbersberg, W.; Hay, M.E.; et al. Bromophycoic acids: Bioactive natural products from a Fijian red alga Callophycus sp. J. Org. Chem. 2012, 77, 8000-8006.

65. Won, T.H.; Jeon, J.; Lee, S.-H.; Rho, B.J.; Oh, K.-B.; Shin, J. Beta-carboline alkaloids derived from the ascidian Synoicum sp. Bioorg. Med. Chem. 2012, 20, 4082-4087.

66. Wang, W.; Nam, S.-J.; Lee, B.-C.; Kang, H. $\beta$-Carboline alkaloids from a Korean tunicate Eudistoma sp. J. Nat. Prod. 2008, 71, 163-166.

67. Won, T.H.; Jeon, J.; Kim, S.-H.; Lee, S.-H.; Rho, B.J.; Oh, D.-C.; Oh, K.-B.; Shin, J. Brominated aromatic furanones and related esters from the ascidian Synoicum sp. J. Nat. Prod. 2012, 75, 2055-2061.

68. Wang, W.; Kim, H.; Nam, S.-J.; Rho, B.J.; Kang, H. Antibacterial butenolides from the Korean tunicate Pseudodistoma antinboja. J. Nat. Prod. 2012, 75, 2049-2054.

69. Sikorska, J.; Parker-Nance, S.; Davies-Coleman, M.T.; Vining, O.B.; Sikora, A.E.; McPhail, K.L. Antimicrobial rubrolides from a South African species of Synoicum tunicate. J. Nat. Prod. 2012, $75,1824-1827$.

70. Trepos, R.; Cervin, G.; Hellio, C.; Pavia, H.; Stensen, W.; Stensvåg, K.; Svendsen, J.-S.; Haug, T.; Svenson, J. Antifouling compounds from the Sub-Arctic ascidian Synoicum pulmonaria: synoxazolidinones A and C, pulmonarins A and B, and synthetic analogues. J. Nat. Prod. 2014, 77, 2105-2113.

71. Jansen, N.; Ohlendorf, B.; Erhard, A.; Bruhn, T.; Bringmann, G.; Imhoff, J.F. Helicusin E, isochromophilone $\mathrm{X}$ and isochromophilone XI: New chloroazaphilones produced by the fungus Bartalinia robillardoides strain LF550. Mar. Drugs 2013, 11, 800-816.

72. Niu, S.; Liu, D.; Hu, X.; Proksch, P.; Shao, Z.; Lin, W. Spiromastixones A-O, antibacterial chlorodepsidones from a deep-sea-derived Spiromastix sp. fungus. J. Nat. Prod. 2014, 77, 1021-1030.

73. Sakoulas, G.; Nam, S.-J.; Loesgen, S.; Fenical, W.; Jensen, P.R.; Nizet, V.; Hensler, M. Novel bacterial metabolites merochlorin A demonstrates in vitro activity against multi-drug resistant methicillin-resistant Staphylococcus aureus. PLoS ONE 2012, 7, e29439.

74. Kaysser, L.; Bernhardt, P.; Nam, S.-J.; Loesgen, S.; Ruby, J.G.; Skewes-Cox, P.; Jensen, P.R.; Fenical, W.; Moore, B.S. Merochlorins A-D, cyclic meroterpenoid antibiotics biosynthesized in divergent pathways with vanadium-dependent chloroperoxidases. J. Am. Chem. Soc. 2012, 134, 11988-11991.

75. Cheng, Y.-B.; Jensen, P.R.; Fenical, W. Cytotoxic and antimicrobial napyradiomycins from two marine-derived Streptomyces strains. Eur. J. Org. Chem. 2013, 2013, 3751-3757.

76. Wu, Z.; Li, S.; Li, J.; Chen, Y.; Saurav, K.; Zhang, Q.; Zhang, H.; Zhang, W.; Zhang, W.; Zhang, S.; Zhang, C. Antibacterial and cytotoxic new napyradiomycins from the marine-derived Streptomyces sp. SCSIO 10428. Mar. Drugs 2013, 11, 2113-2125. 
77. Felder, S.; Dreisigacker, S.; Kehraus, S.; Neu, E.; Bierbaum, G.; Wright, P.R.; Menche, D.; Schäberle, T.F.; König, G.M. Salimabromide: Unexpected chemistry from the obligate marine myxobacterium Enhygromxya salina. Chem. Eur. J. 2013, 19, 9319-9324.

78. Choi, H.; Mascuch, S.J.; Villa, F.A.; Byrum, T.; Teasdale, M.E.; Smith, J.E.; Preskitt, L.B.; Rowley, D.C.; Gerwick, L.; Gerwick, W.H. Honaucins A-C, potent inhibitors of inflammation and bacterial quorum sensing: Synthetic derivatives and structure-activity relationships. Chem. Biol. 2012, 19, 589-598.

79. Montaser, R.; Paul, V.J.; Luesch, H. Modular strategies for structure and function employed by marine cyanobacteria: Characterization and synthesis of pitinoic acids. Org. Lett. 2013, 15, 4050-4053.

80. Kumar, R.; Subramani, R.; Feussner, K.-D.; Aalbersberg, W. Aurantoside K, a new antifungal tetramic acid glycoside from a Fijian marine sponge of the genus Melophlus. Mar. Drugs 2012, 10, 200-208.

81. Angawi, R.F.; Bavestrello, G.; Calcinai, B.; Dien, H.A.; Donnarumma, G.; Tufano, M.A.; Paoletti, I.; Grimaldi, E.; Chianese, G.; Fattorusso, E.; et al. Aurantoside J: A new tetramic acid glycoside from Theonella swinhoei. Insights into the antifungal potential of aurantosides. Mar. Drugs 2011, 9, 2809-2817.

82. Youssef, D.T.A.; Shaala, L.A.; Mohamed, G.A.; Badr, J.M.; Bamanie, F.H.; Ibrahim, S.R.M. Theonellamide $\mathrm{G}$, a potent antifungal and cytotoxic bicyclic glycopeptide from the Red Sea marine sponge Theonella swinhoei. Mar. Drugs 2014, 12, 1911-1923.

83. Singh, A.J.; Dattelbaum, J.D.; Field, J.J.; Smart, Z.; Woolly, E.F.; Barber, J.M.; Heathcott, R.; Miller, J.H.; Northcote, P.T. Structurally diverse hamigerans from the New Zealand marine sponge Hamigera tarangaensis: NMR-directed isolation structure elucidation and antifungal activity. Org. Biomol. Chem. 2013, 11, 8041-8051.

84. Kusama, T.; Tanaka, N.; Sakai, K.; Gonoi, T.; Fromont, J.; Kashiwada, Y.; Kobayashi, J. Agelamadins C-E, bromopyrrole alkaloids comprising oroidin and 3-hydroxykynurenine from a marine sponge Agelas sp. Org. Lett. 2014, 16, 5176-5179.

85. Tanaka, N.; Kusama, T.; Takahashi-Nakaguchi, A.; Gonoi, T.; Fromont, J.; Kobayashi, J. Nagelamides U-W, bromopyrrole alkaloids from a marine sponge Agelas sp. Tetrahedron Lett. 2013, 54, 3794-3796.

86. Tanaka, N.; Kusama, T.; Takahashi-Nakaguchi, A.; Gonoi, T.; Fromont, J.; Kobayashi, J. Nagelamides $\mathrm{X}-\mathrm{Z}$, dimeric bromopyrrole alkaloids from a marine sponge Agelas sp. Org. Lett. 2013, 15, 3262-3265.

87. Nakamura, K.; Kusama, T.; Tanaka, N.; Sakai, K.; Gonoi, T.; Fromont, J.; Kobayashi, J. 2-Debromonagelamide U, 2-debromomukanadin G, and 2-debromonagelamide P from marine sponge Agelas sp. Heterocycles 2015, 90, 425-431.

88. Li, X.-D.; Miao, F.-P.; Yin, X.-L.; Liu, J.-L.; Ji, N.-Y. Sesquiterpenes from the marine red alga Laurencia composita. Fitoterapia 2012, 83, 1191-1195.

89. Yu, X.-Q.; He, W.-F.; Liu, D.-Q.; Feng, M.-T.; Fang, Y.; Wang, B.; Feng, L.-H.; Guo, Y.-W.; Mao, S.-C. A seco-laurane sesquiterpene and related laurane derivatives from the red alga Laurencia okamurai Yamada. Phytochemistry 2014, 103, 162-170. 
90. Xu, X.; Yin, L.; Wang, Y.; Wang, S.; Song, F. A new bromobenzyl methyl sulphoxide from marine red alga Symphyocladia latiuscula. Nat. Prod. Res. 2013, 27, 723-726.

91. Xu, X.; Piggott, A.M.; Yin, L.; Capon, R.J.; Song, F. Symphyocladins A-G: Bromophenol adducts from a Chinese marine red alga, Symphyocladia latiuscula. Tetrahedron Lett. 2012, 53, 2103-2106.

92. Xu, X.; Yin, L.; Gao, J.; Gao, L.; Song, F. Antifungal bromophenols from marine red alga Symphyocladia latiuscula. Chem. Biodivers. 2014, 11, 807-811.

93. Maltseva, A.L.; Kotenko, O.N.; Shabalin, K.A.; Shavarda, A.L.; Winson, M.K.; Ostrovsky, A.N. Novel brominated fungicidal alkaloid isolated from the marine bryozoan Chartella membranaceatruncata (Smitt, 1868). Studi Trent. Sci. Nat. 2014, 94, 163-168.

94. Wyche, T.P.; Piotrowski, J.S.; Hou, Y.; Braun, D.; Deshpande, R.; McIlwain, S.; Ong, I.M.; Myers, C.L.; Guzei, I.A.; Westler, W.M.; et al. Forazoline A: Marine-derived polyketide with antifungal in vivo efficacy. Angew. Chem. Int. Ed. 2014, 53, 11583-11586.

95. Giri, S.; Kindo, A.J. A review of Candida species causing blood stream infection. Indian J. Med. Microbiol. 2012, 30, 270-278.

96. Zaragoza, R.; Peman, J. The diagnostic and therapeutic approach to fungal infections in critical care settings. Adv. Sepsis 2008, 6, 90-98.

97. Bui, T.-H.; Wray, V.; Nimtz, M.; Fossen, T.; Preisitsch, M.; Schröder, G.; Wende, K.; Heiden, S.E.; Mundt, S. Balticidins A-D, antifungal hassallidin-like lipopeptides from the Baltic Sea cyanobacterium Anabaena cylindrica Bio33. J. Nat. Prod. 2014, 77, 1287-1296.

98. Bui, T.-H.; Wray, V.; Nimtz, M.; Fossen, T.; Preisitsch, M.; Schröder, G.; Wende, K.; Heiden, S.E.; Mundt, S. Balticidins A-D, antifungal hassallidin-like lipopeptides from the Baltic Sea cyanobacterium Anabaena cylindrica Bio33. J. Nat. Prod. 2014, 77, 1287-1296; Erratum in 2015, 78, 345

99. Media centre: Fact sheets. World Health Organization. Available online: http://www.who.int/ mediacentre/factsheets/en (accessed on 1 May 2015).

100. Burrows, J.N.; Elliott, R.L.; Kaneko, T.; Mowbray, C.E.; Waterson, D. The role of modern drug discovery in the fight against neglected and tropical diseases. Med. Chem. Commun. 2014, 5, $688-700$.

101. Sachs-Barrable, K.; Conway, J.; Gershkovich, P.; Ibrahim, F.; Wasan, K.M. The use of the United States FDA programs as a strategy to advance the development of drug products for neglected tropical diseases. Drug Dev. Ind. Pharm. 2014, 40, 1429-1434.

102. Njoroge, M.; Njuguna, N.M.; Mutai, P.; Ongarora, D.S.B.; Smith, P.W.; Chibale, K. Recent approaches to chemical discovery and development against malaria and the neglected tropical diseases human African trypanosomiasis and schistosomiasis. Chem. Rev. 2014, 114, 11138-11163.

103. Silva-Jardim, I.; Thiemann, O.H.; Anibal, F.F. Leishmaniasis and Chagas disease chemotherapy: A critical review. J. Braz. Chem. Soc. 2014, 25, 1810-1823.

104. Xu, M.; Andrews, K.T.; Birrell, G.W.; Tran, T.L.; Camp, D.; Davis, R.A.; Quinn, R.J. Psammaplysin $\mathrm{H}$, a new antimalarial bromotyrosine alkaloid from a marine sponge of the genus Pseudoceratina. Bioorg. Med. Chem. Lett. 2011, 21, 846-848. 
105. Mudianta, I.W.; Skinner-Adams, T.; Andrews, K.T.; Davis, R.A.; Hadi, T.A.; Hayes, P.Y.; Garson, M.J. Psammaplysin derivatives from the Balinese marine sponge Aplysinella strongylata. J. Nat. Prod. 2012, 75, 2132-2143.

106. Mani, L.; Jullian, V.; Mourkazel, B.; Valentin, A.; Dubois, J.; Cresteil, T.; Folcher, E.; Hooper, J.N.A.; Erpenbeck, D.; Aalbersberg, W.; et al. New antiplasmodial bromotyrosine derivatives from Suberea ianthelliformis Lendenfeld, 1888. Chem. Biodivers. 2012, 9, 1436-1451.

107. Galeano, E.; Thomas, O.P.; Robledo, S.; Munoz, D.; Martinez, A. Antiparasitic bromotyrosine derivatives from the marine sponge Verongula rigida. Mar. Drugs 2011, 9, 1902-1913.

108. Feng, Y.; Davis, R.A.; Sykes, M.L.; Avery, V.M.; Quinn, R.J. Iotrochamides A and B, antitrypanosomal compounds from the Australian marine sponge Iotrochota sp. Bioorg. Med. Chem. Lett. 2012, 22, 4873-4876.

109. Davis, R.A.; Buchanan, M.S.; Duffy, S.; Avery, V.M.; Charman, S.A.; Charman, W.N.; White, K.L.; Shackleford, D.M.; Edstein, M.D.; Andrews, K.T.; et al. Antimalarial activity of pyrroloiminoquinones from the Australian marine sponge Zyzzya sp. J. Med. Chem. 2012, 55, 5851-5858.

110. Chianese, G.; Fattorusso, E.; Scala, F.; Teta, R.; Calcinai, B.; Bavestrello, G.; Dien, H.A.; Kaiser, M.; Tasdemir, D.; Taglialatela-Scafati, O. Manadoperoxides, a new class of potent antitrypanosomal agents of marine origin. Org. Biomol. Chem. 2012, 10, 7197-7207.

111. Stout, E.P.; Cervantes, S.; Prudhomme, J.; France, S.; la Clair, J.J.; le Roch, K.; Kubanek, J. Bromophycolide A targets heme crystallization in the human malaria parasite Plasmodium falciparum. ChemMedChem 2011, 6, 1572-1577.

112. Chan, S.T.S.; Pearce, A.N.; Page, M.J.; Kaiser, M.; Copp, B.R. Antimalarial $\beta$-carbolines from the New Zealand ascidian Pseudodistoma opacum. J. Nat. Prod. 2011, 74, 1972-1979.

113. Carroll, A.R.; Wild, S.J.; Duffy, S.; Avery, V.M. Kororamide A, a new tribrominated indole alkaloid from the Australian bryozoan Amathia tortuosa. Tetrahedron Lett. 2012, 53, 2873-2875.

114. Balunas, M.J.; Grosso, M.F.; Villa, F.A.; Engene, N.; McPhail, K.L.; Tidgewell, K.; Pineda, L.M.; Gerwick, L.; Spadafora, C.; Kyle, D.E.; et al. Coibacins A-D, antileishmanial marine cyanobacterial polyketides with intriguing biosynthetic origins. Org. Lett. 2012, 14, 3878-3881.

115. Sagar, S.; Kaur, M.; Minneman, K.P. Antiviral lead compounds from marine sponges. Mar. Drugs 2010, 8, 2619-2638.

116. Galeano, E.; Rojas, J.J.; Martinez, A. Pharmacological developments obtained from marine natural products and current pipeline perspective. Nat. Prod. Commun. 2011, 6, 287-300.

117. Galeano, E.; Martinez, A.; Thomas, O.P.; Robledo, S.; Munoz, D. Antiparasitic bromotyrosine derivatives from the Caribbean marine sponge Aiolochroia crassa. Química Nova 2012, 35, 1189-1193.

118. Gómez-Archila, L.G.; Zapata, W.; Galeano, E.; Martínez, A.; Díaz, F.J.; Rugeles, M.T. Bromotyrosine derivatives from marine sponges inhibit the HIV-1 replication in vitro. Vitae 2014, 21, 114-125.

119. Mejia, E.J.; Loveridge, S.T.; Stepan, G.; Tsai, A.; Jones, G.S.; Barnes, T.; White, K.N.; Drašković, M.; Tenney, K.; Tsiang, M.; et al. Study of marine natural products including resorcyclic acid lactones from Humicola fuscoatra that reactivate latent HIV-1 expression in an in vitro model of central memory CD4+ T cells. J. Nat. Prod. 2014, 77, 618-624. 
120. Wu, J.; Xiao, Q.; Xu, J.; Li, M.-Y.; Pan, J.-Y.; Yang, M. Natural products from true mangrove flora: Source, chemistry and bioactivities. Nat. Prod. Rep. 2008, 25, 955-981.

121. Zhang, G.; Sun, S.; Zhu, T.; Lin, Z.; Gu, J.; Li, D.; Gu, Q. Antiviral isoindolone derivatives from an endophytic fungus Emericella sp. associated with Aegiceras corniculatum. Phytochemistry 2011, 72, 1436-1442.

122. Smitha, D.; Kumar, M.M.K.; Ramana, H.; Rao, D.V. Rubrolide R: A new furanone metabolite from the ascidian Synoicum of the Indian Ocean. Nat. Prod. Res. 2014, 28, $12-17$.

123. Gupta, D.K.; Kaur, P.; Leong, S.T.; Tan, L.T.; Prinsep, M.R.; Chu, J.J.H. Anti-Chikungunya viral activities of aplysiatoxin-related compounds from the marine cyanobacterium Trichodesmium erythraeum. Mar. Drugs 2014, 12, 115-127.

124. Park, S.-H.; Song, J.-H.; Kim, T.; Shin, W.-S.; Park, G.M.; Lee, S.; Kim, Y.-J.; Choi, P.; Kim, H.; Kim, H.-S.; et al. Anti-human rhinoviral activity of polybromocatechol compounds isolated from the Rhodophyta, Neorhodomela aculeata. Mar. Drugs 2012, 10, 2222-2233.

125. Treitler, D.S.; Li, Z.; Krystal, M.; Meanwell, N.A.; Snyder, S.A. Evaluation of HIV-1 inhibition by stereoisomers and analogues of the sesquiterpenoid hydroquinone peyssonol A. Bioorg. Med. Chem. Lett. 2013, 23, 2192-2196.

126. Lyakhova, E.G.; Kolesnikova, S.A.; Kalinovsky, A.I.; Afiyatullov, S.S.; Dyshlovoy, S.A.; Krasokhin, V.B.; Minh, C.V.; Stonik, V.A. Bromine-containing alkaloids from the marine sponge Penares sp. Tetrahedron Lett. 2012, 53, 6119-6122.

127. Martín, M.J.; Coello, L.; Fernández, R.; Reyes, F.; Rodríguez, A.; Murcia, C.; Garranzo, M.; Mateo, C.; Sánchez-Sancho, F.; Bueno, S.; et al. Isolation and first total synthesis of PM050489 and PM060184, two new marine anticancer compounds. J. Am. Chem. Soc. 2013, 135, 10164-10171.

128. Lee, Y.; Wang, W.; Kim, H.; Giri, A.G.; Won, D.H.; Hahn, D.; Baek, K.R.; Lee, J.; Yang, I.; Choi, H.; et al. Phorbaketals L-N, cytotoxic sesterterpenoids isolated from the marine sponge of the genus Phorbas. Bioorg. Med. Chem. Lett. 2014, 24, 4095-4098.

129. Lee, Y.-J.; Han, S.; Lee, H.-S.; Kang, J.S.; Yun, J.; Sim, C.J.; Shin, H.J.; Lee, J.S. Cytotoxic psammaplysin analogues from a Suberea sp. marine sponge and the role of the spirooxepinisoxazoline in their activity. J. Nat. Prod. 2013, 76, 1731-1736.

130. Alarif, W.M.; Abdel-Lateff, A.; Al-Lihaibi, S.S.; Ayyad, S.-E.N.; Badria, F.A. A new cytotoxic brominated acetylenic hydrocarbon from the marine sponge Haliclona sp. with a selective effect against human breast cancer. Z. Naturforsch. 2013, 68c, 70-75.

131. Pham, C.-D.; Hartmann, R.; Böhler, P.; Stork, B.; Wesselborg, S.; Lin, W.; Lai, D.; Proksch, P. Callyspongiolide a cytotoxic macrolide from the marine sponge Callyspongia sp. Org. Lett. 2014, 16, 266-269.

132. Lorente, A.; Gil, A.; Fernández, R.; Cuevas, C.; Albericio, F.; Álvarez, M. Phormidolides B and C, cytotoxic agents from the sea: Enantioselective synthesis of the macrocyclic core. Chem. Eur. J. 2015, 21, 150-156.

133. Morinaka, B.I.; Molinski, T.F. Mollenyne A, a long-chain chlorodibromohydrin amide from the sponge Spirastrella mollis. Org. Lett. 2011, 13, 6338-6341.

134. Aoki, N.; Yamamoto, K.; Ogawa, T.; Ohta, E.; Ikeuchi, T.; Kamemura, K.; Ikegami, S.; Ohta, S. Bromotheoynic acid, a brominated acetylenic acid from the marine sponge Theonella swinhoei. Nat. Prod. Res. 2013, 27, 117-122. 
135. Fouad, M.A.; Debbab, A.; Wray, V.; Müller, W.E.G.; Proksch, P. New bioactive alkaloids from the marine sponge Stylissa sp. Tetrahedron 2012, 68, 10176-10179.

136. Prawat, H.; Mahidol, C.; Kaweetripob, W.; Wittayalai, S.; Ruchirawat, S. Iodo-sesquiterpene hydroquinone and brominated indole alkaloids from the Thai sponge Smenospongia sp. Tetrahedron 2012, 68, 6881-6886.

137. Teta, R.; Irollo, E.; Della Sala, G.; Pirozzi, G.; Mangoni, A.; Costantino, V. Smenamides A and $\mathrm{B}$, chlorinated peptide/polyketide hybrids containing a dolapyrrolidinone unit from the Caribbean sponge Smenospongia aurea. Evaluation of their role as leads in antitumor drug research. Mar. Drugs 2013, 11, 4451-4463.

138. Esposito, G.; Teta, R.; Miceli, R.; Ceccarelli, L.S.; Della Sala, G.; Camerlingo, R.; Irollo, E.; Mangoni, A.; Pirozzi, G.; Costantino, V. Isolation and assessment of the in vitro anti-tumor activity of smenothiazole $\mathrm{A}$ and $\mathrm{B}$, chlorinated thiazole-containing peptide/polyketides from the Caribbean sponge, Smenospongia aurea. Mar. Drugs 2015, 13, 444-459.

139. Niemann, H.; Lin, W.; Müller, W.E.G.; Kubbutat, M.; Lai, D.; Proksch, P. Trimeric hemibastadin congener from the marine sponge Ianthella basta. J. Nat. Prod. 2013, 76, 121-125.

140. Shaala, L.A.; Youssef, D.T.A.; Sulaiman, M.; Behery, F.A.; Foudah, A.I.; el Sayed, K.A. Subereamolline A as a potent breast cancer migration, invasion and proliferation inhibitor and bioactive dibrominated alkaloids from the Red Sea sponge Pseudoceratina arabica. Mar. Drugs 2012, 10, 2492-2508.

141. Tran, T.D.; Pham, N.B.; Fechner, G.; Hooper, J.N.A.; Quinn, R.J. Bromotyrosine alkaloids from the Australian marine sponge Pseudoceratina verrucosa. J. Nat. Prod. 2013, 76, 516-523.

142. Xu, Y.; Lang, J.-H.; Jiao, W.-H.; Wang, R.-P.; Peng, Y.; Song, S.-J.; Zhang, B.-H.; Lin, H.-W. Formamido-diterpenes from the South China Sea sponge Acanthella cavernosa. Mar. Drugs 2012, 10, 1445-1458.

143. García-Ruiz, C.; Sarabia, F. Chemistry and biology of bengamides and bengazoles, bioactive natural products from Jaspis sponges. Mar. Drugs 2014, 12, 1580-1622.

144. Hamilton, G. Cytotoxic effects of fascaplysin against small cell lung cancer cell lines. Mar. Drugs 2014, 12, 1377-1389.

145. Saha, S.; Reddy, C.V.R.; Chiranjeevi, T.; Addepally, U.; Rao, T.S.C.; Patro, B. The first total synthesis and biological evaluation of marine natural products ma'edamines A and B. Bioorg. Med. Chem. Lett. 2013, 23, 1013-1016.

146. Saha, S.; Reddy, C.V.R.; Xu, S.; Sankar, S.; Neamati, N.; Patro, B. Synthesis and SAR studies of marine natural products ma'edamines A, B and their analogues. Bioorg. Med. Chem. Lett. 2013, 23, 5135-5139.

147. Kim, G.D.; Cheong, O.J.; Bae, S.Y.; Shin, J.; Lee, S.K. 6"-Debromohamacanthin A, a bis (indole) alkaloid, inhibits angiogenesis by targeting the VEGFR2-mediated P13K/AKT/mTOR signaling pathways. Mar. Drugs 2013, 11, 1087-1103.

148. Smith, S.E.; Dello Buono, M.C.; Carper, D.J.; Coleman, R.S.; Day, B.W. Structure elucidation of phase I metabolites of the microtubule perturbagens: Ceratamines A and B. J. Nat. Prod. 2014, $77,1572-1578$. 
149. Su, J.-H.; Chen, Y.-C.; el-Shazly, M.; Du, Y.-C.; Su, C.-W.; Tsao, C.-W.; Liu, L.-L.; Chou, Y.; Chang, W.-B.; Su, Y.-D.; et al. Towards the small and the beautiful: A small dibromotyrosine derivative from Pseudoceratina sp. sponge exhibits potent apoptotic effect through targeting IKK/NFאB signaling pathway. Mar. Drugs 2013, 11, 3168-3185.

150. Suzuki, M.; Ueoka, R.; Takada, K.; Okada, S.; Ohtsuka, S.; Ise, Y.; Matsunaga, S. Isolation of spirastrellolides A and B from a marine sponge Epipolasis sp. and their cytotoxic activities. J. Nat. Prod. 2012, 75, 1192-1195.

151. Sun, W.-S.; Su, S.; Zhu, R.-X.; Tu, G.-Z.; Cheng, W.; Liang, H.; Guo, X.-Y.; Zhao, Y.-Y.; Zhang, Q.-Y. A pair of unprecedented spiro-trisindole enantiomers fused through a five-member ring from Laurencia similis. Tetrahedron Lett. 2013, 54, 3617-3620.

152. Cen-Pacheco, F.; Villa-Pulgarin, J.A.; Mollinedo, F.; Norte, M.; Daranas, A.H.; Fernández, J.J. Cytotoxic oxasqualenoids from the red alga Laurencia viridis. Eur. J. Med. Chem. 2011, 46, 3302-3308.

153. Cen-Pacheco, F.; Villa-Pulgarin, J.A.; Mollinedo, F.; Martín, M.N.; Fernández, J.J.; Daranas, A.H. New polyether triterpenoids from Laurencia viridis and their biological evalution. Mar. Drugs 2011, 9, 2220-2235.

154. Cen-Pacheco, F.; Mollinedo, F.; Villa-Pulgarín, J.A.; Norte, M.; Fernández, J.J.; Daranas, A.H. Saiyacenols A and B: The key to solve the controversy about the configuration of aplysiols. Tetrahedron 2012, 68, 7275-7279.

155. Wu, N.; Luo, J.; Jiang, B.; Wang, L.; Wang, S.; Wang, C.; Fu, C.; Li, J.; Shi, D. Marine bromophenol bis (2,3-dibromo-4,5-dihydroxy-phenyl)methane inhibits the proliferation, migration, and invasion of hepatocellular carcinoma cells via modulating $\beta 1$-integrin/FAK signaling. Mar. Drugs 2015, 13, 1010-1025.

156. Antunes, E.M.; Afolayan, A.F.; Chiwakata, M.T.; Fakee, J.; Knott, M.G.; Whibley, C.E.; Hendricks, D.T.; Bolton, J.J.; Beukes, D.R. Identification and in vitro anti-esophageal cancer activity of a series of halogenated monoterpenes isolated from the South African seaweeds Plocamium suhrii and Plocamium cornutum. Phytochemistry 2011, 72, 769-772.

157. Tadesse, M.; Svenson, J.; Jaspars, M.; Strøm, M.B.; Abdelrahman, M.H.; Andersen, J.H.; Hansen, E.; Kristiansen, P.E.; Stensvåg, K.; Haug, T. Synoxazolidinone C; a bicyclic member of the synoxazolidinone family with antibacterial and anticancer activities. Tetrahedron Lett. 2011, 52, 1804-1806.

158. Murcia, C.; Coello, L.; Fernández, R.; Martín, M.J.; Reyes, F.; Francesch, A.; Munt, S.; Cuevas, C. Tanjungides A and B: New antitumoral bromoindole derived compounds from Diazona cf Formosa. Isolation and total synthesis. Mar. Drugs 2014, 12, 1116-1130.

159. Ankisetty, S.; Khan, S.I.; Avula, B.; Gochfeld, D.; Khan, I.A.; Slattery, M. Chlorinated didemnins from the tunicate Trididemnum solidum. Mar. Drugs 2013, 11, 4478-4486.

160. Lin, M.-C.; Chen, B.-W.; Huang, C.-Y.; Dai, C.-F.; Hwang, T.-L.; Sheu, J.-H. Eunicellin-based diterpenoids from the Formosan soft coral Klyxum molle with inhibitory activity on superoxide generation and elastase release by neutrophils. J. Nat. Prod. 2013, 76, 1661-1667.

161. Li, C.; Jiang, M.; La, M.-P.; Li, T.-J.; Tang, H.; Sun, P.; Liu, B.-S; Yi, Y.-H.; Liu, Z.; Zhang, W. Chemistry and tumor cell growth inhibitory activity of 11,20-epoxy-3Z,5(6)E-diene briaranes from the South China Sea gorgonian Dichotella gemmacea. Mar. Drugs 2013, 11, 1565-1582. 
162. El-Elimat, T.; Raja, H.A.; Day, C.S.; Chen, W.-L.; Swanson, S.M.; Oberlies, N.H. Greensporones: Resorcylic acid lactones from an aquatic Halenospora sp. J. Nat. Prod. 2014, 77, 2088-2098.

163. Qin, C.; Lin, X.; Lu, X.; Wang, J.; Zhou, X.; Liao, S.; Tu, Z.; Xu, S.; Liu, Y. Sesquiterpenoids and xanthones derivatives produced by sponge-derived fungus Stachybotry sp. HH1 ZSDS1F1-2. J. Antibiot. 2015, 68, 121-125.

164. Shang, Z.; Li, X.-M.; Li, C.-S.; Wang, B.-G. Diverse secondary metabolites produced by marine-derived fungus Nigrospora sp. MA75 on various culture media. Chem. Biodivers. 2012, 9, 1338-1348.

165. Huang, H.; Wang, F.; Luo, M.; Chen, Y.; Song, Y.; Zhang, W.; Zhang, S.; Ju, J. Halogenated anthraquinones from the marine-derived fungus Aspergillus sp. SCSIO F063. J. Nat. Prod. 2012, $75,1346-1352$.

166. Amagata, T.; Tanaka, M.; Yamada, T.; Chen, Y.-P.; Minoura, K.; Numata, A. Additional cytotoxic substances isolated from the sponge-derived Gymnascella dankaliensis. Tetrahedron Lett. 2013, 54, 5960-5962.

167. Rukachaisirikul, V.; Kannai, S.; Klaiklay, S.; Phongpaichit, S.; Sakayaroj, J. Rare 2-phenylpyran-4-ones from the seagrass-derived fungi Polyporales PSU-ES44 and PSU-ES83. Tetrahedron 2013, 69, 6981-6986.

168. Yamada, T.; Jinno, M.; Kikuchi, T.; Kajimoto, T.; Numata, A.; Tanaka, R. Three new azaphilones produced by a marine fish-derived Chaetomium globosum. J. Antibiot. 2012, 65, 413-417.

169. Zang, L.-Y.; Wei, W.; Wang, T.; Guo, Y.; Tan, R.-X.; Ge, H.-M. Isochromophilones from an endophytic fungus Diaporthe sp. Nat. Prod. Bioprospect. 2012, 2, 117-120.

170. Vansteelandt, M.; Blanchet, E.; Egorov, M.; Petit, F.; Toupet, L.; Bondon, A.; Montaeu, F.; le Bizec, B.; Thomas, O.P.; Pouchus, Y.F.; et al. Ligerin, an antiproliferative chlorinated sesquiterpenoid from a marine-derived Penicillium strain. J. Nat. Prod. 2013, 76, 297-301.

171. Wu, G.; Lin, A.; Gu, Q.; Zhu, T.; Li, D. Four new chloro-eremophilane sesquiterpenes from an Antarctic deep-sea derived fungus, Penicillium sp. PR19N-1. Mar. Drugs 2013, 11, 1399-1408.

172. Luo, S.; Kang, H.-S.; Krunic, A.; Chlipala, G.E.; Cai, G.; Chen, W.-L.; Franzblau, S.G.; Swanson, S.M.; Orjala, J. Carbamidocyclophanes F and G with anti-Mycobacterium tuberculosis activity from the cultured freshwater cyanobacterium Nostoc sp. Tetrahedron Lett. 2014, 55, 686-689.

173. Kim, H.; Krunic, A.; Lantvit, D.; Shen, Q.; Kroll, D.J.; Swanson, S.M.; Orjala, J. Nitrile-containing fischerindoles from the cultured cyanobacterium Fischerella sp. Tetrahedron 2012, 68, 3205-3209.

174. Chang, T.T.; More, S.V.; Lu, I.-H.; Hsu, J.-C.; Chen, T.-J.; Jen, Y.C.; Lu, C.-K.; Li, W.-S. Isomalyngamide A, A-1 and their analogs suppress cancer cell migration in vitro. Eur. J. Med. Chem. 2011, 46, 3810-3819.

175. Malloy, K.L.; Villa, F.A.; Engene, N.; Matainaho, T.; Gerwick, L.; Gerwick, W.H. Malyngamide 2, an oxidized lipopeptide with nitric oxide inhibiting activity from a Papua New Guinea marine cyanobacterium. J. Nat. Prod. 2011, 74, 95-98. 
176. Shaala, L.A.; Youssef, D.T.A.; McPhail, K.L.; Elbandy, M. Malyngamide 4, a new lipopeptide from the Red Sea marine cyanobacterium Moorea producens (formerly Lyngbya majuscula). Phytochem. Lett. 2013, 6, 183-188.

177. Choi, H.; Mevers, E.; Byrum, T.; Valeriote, F.A.; Gerwich, W.H. Lyngbyabellins K-N from two Palmyra Atoll collections of the marine cyanobacterium Moorea bouillonii. Eur. J. Org. Chem. 2012, 5141-5150.

178. Pan, E.; Jamison, M.; Yousufuddin, M.; MacMillan, J.B. Ammosamide D, an oxidatively ring opened ammosamide analog from a marine-derived Streptomyces variabilis. Org. Lett. 2012, 14, 2390-2393.

179. Alvarez-Mico, X.; Jensen, P.R.; Fenical, W.; Hughes, C.C. Chlorizidine, a cytotoxic $5 H$-pyrrolo[2,1-a]isoindol-5-one-containing alkaloid from a marine Streptomyces sp. Org. Lett. 2013, 15, 988-991.

180. Zhang, W.; Liu, Z.; Li, S.; Yang, T.; Zhang, Q.; Ma, L.; Tian, X.; Zhang, H.; Huang, C.; Zhang, S.; et al. Spiroindimicins A-D: New bisindole alkaloids from a deep-sea-derived actinomycete. Org. Lett. 2012, 14, 3364-3367.

181. Zhang, W.; Ma, L.; Li, S.; Liu, Z.; Chen, Y.; Zhang, H.; Zhang, G.; Zhang, Q.; Tian, X.; Yuan, C.; et al. Indimicins A-E, bisindole alkaloids from the deep-sea-derived Streptomyces sp. SCSIO 03032. J. Nat. Prod. 2014, 77, 1887-1892.

182. Farnaes, L.; Coufal, N.G.; Kauffman, C.A.; Rheingold, A.L.; DiPasquale, A.G.; Jensen, P.R.; Fenical, W. Napyradiomycin derivatives, produced by a marine-derived actinomycete, illustrate cytotoxicity by induction of apoptosis. J. Nat. Prod. 2014, 77, 15-21.

183. Andrianasolo, E.H.; Haramaty, L.; Rosario-Passapera, R.; Vetriani, C.; Falkowski, P.; White, E.; Lutz, R. Ammonificins $\mathrm{C}$ and $\mathrm{D}$, hydroxyethylamine chromene derivatives from a cultured marine hydrothermal vent bacterium, Thermovibrio ammonificans. Mar. Drugs 2012, 10, 2300-2311.

184. Patiño C, L.P.; Muniain, C.; Knott, M.E.; Puricelli, L.; Palermo, J.A. Bromopyrrole alkaloids isolated from the Patagonian bryozoan Aspidostoma giganteum. J. Nat. Prod. 2014, 77, 1170-1178.

185. Nuzzo, G.; Ciavatta, M.L.; Kiss, R.; Mathieu, V.; Leclercqz, H.; Manzo, E.; Villani, G.; Mollo, E.; Lefranc, F.; D'Souza, L.; et al. Chemistry of the nudibranch Aldisa andersoni: Structure and biological activity of phorbazole metabolites. Mar. Drugs 2012, 10, 1799-1811.

186. Maschek, J.A.; Mevers, E.; Diyabalanage, T.; Chen, L.; Ren, Y.; McClintock, J.B.; Amsler, C.D.; $\mathrm{Wu}$, J.; Baker, B.J. Palmadorin chemodiversity from the Antarctic nudibranch Austrodoris kerguelenensis and inhibition of Jak2/STAT5-dependent HEL leukemia cells. Tetrahedron 2012, 68, 9095-9104.

187. Bailly, C. Anticancer properties of lamellarins. Mar. Drugs 2015, 13, 1105-1123.

188. Esmaeelian, B.; Benkendorff, K.; Johnston, M.R.; Abbott, C.A. Purified brominated indole derivatives from Dicathais orbita induce apoptosis and cell cycle arrest in colorectal cancer cell lines. Mar. Drugs 2013, 11, 3802-3822.

189. Esmaeelian, B.; Abbott, C.A.; le Leu, R.K.; Benkendorff, K. 6-Bromoisatin found in muricid mollusc extracts inhibits colon cancer cell proliferation and induces apoptosis, preventing early stage tumor formation in a colorectal cancer rodent model. Mar. Drugs 2014, 12, 17-35. 
190. Hegazy, M.-E.F.; Moustfa, A.Y.; Mohamed, A.E.-H.H.; Alhammady, M.A.; Elbehairi, S.E.I.; Ohta, S.; Paré, P.W. New cytotoxic halogenated sesquiterpenes from the Egyptian sea hare, Aplysia oculifera. Tetrahedron Lett. 2014, 55, 1711-1714.

191. Li, K.; Li, X.-M.; Gloer, J.B.; Wang, B.-G. Isolation, characterization, and antioxidant activity of bromophenols of the marine red alga Rhodomela confervoides. J. Agric. Food Chem. 2011, 59, 9916-9921.

192. Li, K.; Li, X.-M.; Gloer, J.B.; Wang, B.-G. New nitrogen-containing bromophenols from the marine red alga Rhodomela confervoides and their radical scavenging activity. Food Chem. 2012, $135,868-872$.

193. Xu, X.; Yin, L.; Gao, L.; Gao, J.; Chen, J.; Li, J.; Song, F. Two new bromophenols with radical scavenging activity from marine red alga Symphyocladia latiuscula. Mar. Drugs 2013, 11, 842-847.

194. Olsen, E.K.; Hansen, E.; Isaksson, J.; Andersen, J.H. Cellular antioxidant effect of four bromophenols from the red algae, Vertebrata Ianosa. Mar. Drugs 2013, 11, 2769-2784.

195. Longeon, A.; Copp, B.R.; Quévrain, E.; Roué, M.; Kientz, B.; Cresteil, T.; Petek, S.; Debitus, C.; Bourguet-Kondracki, M.-L. Bioactive indole derivatives from the South Pacific marine sponges Rhopaloeides odorabile and Hyrtios sp. Mar. Drugs 2011, 9, 879-888.

196. Utkina, N.K. Antioxidant activity of zyzzyanones and makaluvamines from the marine sponge Zyzzya fuliginosa. Nat. Prod. Commun. 2013, 8, 1551-1552.

197. Hwang, B.S.; Lee, K.; Yang, C.; Jeong, E.J.; Rho, J.-R. Characterization and anti-inflammatory effects of iodinated acetylenic acids isolated from the marine sponges Suberites mammilaris and Suberites japonicas. J. Nat. Prod. 2013, 76, 2355-2359.

198. Li, J.L.; Han, S.C.; Yoo, E.S.; Shin, S.; Hong, J.; Cui, Z.; Li, H.; Jung, J.H. Anti-inflammatory amino acid derivatives from the ascidian Herdmania momus. J. Nat. Prod. 2011, 74, 1792-1797.

199. Liaw, C.-C.; Kuo, Y.-H.; Lin, Y.-S.; Hwang, T.-L.; Shen, Y.-C. Frajunolides L-O, four new 8-hydroxybriarane diterpenoids from the gorgonian Junceella fragilis. Mar. Drugs 2011, 9, 1477-1486.

200. Liaw, C.-C.; Lin, Y.-C.; Lin, Y.-S.; Chen, C.-H.; Hwang, T.-L.; Shen, Y.-C. Four new briarane diterpenoids from Taiwanese gorgonian Junceella fragilis. Mar. Drugs 2013, 11, 2042-2053.

201. Chang, J.-Y.; Liaw, C.-C.; Fazary A.E.; Hwang, T.-L.; Shen Y.-C. New briarane diterpenoids from the gorgonian coral Junceella juncea. Mar. Drugs 2012, 10, 1321-1330.

202. Su, Y.-D.; Cheng, C.-H.; Chen, W.-F.; Chang, Y.-C.; Chen, Y.-H.; Hwang, T.-L.; Wen, Z.-H.; Wang, W.-H.; Fang, L.-S.; Chen, J.-J.; et al. Briarenolide J, the first 12-chlorobriarane diterpenoid from an octocoral Briareum sp. (Briareidae). Tetrahedron Lett. 2014, 55, 6065-6067.

203. Conda-Sheridan, M.; Marler, L.; Park, E.-J.; Kondratyuk, T.P.; Jermihov, K.; Mesecar, A.D.; Pezzuto, J.M.; Asolkar, R.N.; Fenical, W.; Cushman, M. Potential chemopreventive agents based on the structure of the lead compound 2-bromo-1-hydroxyphenazine, isolated from Streptomyces species, strain CNS284. J. Med. Chem. 2010, 53, 8688-8699.

204. Kondratyuk, T.P.; Park, E.-J.; Yu, R.; van Breemen, R.B.; Asolkar, R.N.; Murphy, B.T.; Fenical, W.; Pezzuto, J.M. Novel marine phenazines as potential cancer chemopreventive and anti-inflammatory agents. Mar. Drugs 2012, 10, 451-464.

205. Kita, M.; Kigoshi, H. Marine natural products that interfere with multiple cytoskeletal protein interactions. Nat. Prod. Rep. 2015, 32, 534-542. 
206. Shengule, S.R.; Loa-Kum-Cheung, W.L.; Parish, C.R.; Blairvacq, M.; Meijer, L.; Nakao, Y.; Karuso, P. A one-pot synthesis and biological activity of ageladine A and analogues. J. Med. Chem. 2011, 54, 2492-2503.

207. Ebada, S.S.; Linh, M.H.; Longeon, A.; de Voogd, N.J.; Durieu, E.; Meijer, L.; Bourguet-Kondracki, M.-L.; Singab, A.N.B.; Müller, W.E.G.; Proksch, P. Dispacamide E and other bioactive bromopyrrole alkaloids from two Indonesian marine sponges of the genus Stylissa. Nat. Prod. Res. 2015, 29, 231-238.

208. Qin, J.; Su, H.; Zhang, Y.; Gao, J.; Zhu, L.; Wu, X.; Pan, H.; Li, X. Highly brominated metabolites from marine red alga Laurencia similis inhibit protein tyrosine phosphatase 1B. Bioorg. Med. Chem. Lett. 2010, 20, 7152-7154.

209. Tadesse, M.; Svenson, J.; Sepčić, K.; Trembleau, L.; Engqvist, M.; Andersen, J.H.; Jaspars, M.; Stensvåg, K.; Haug, T. Isolation and synthesis of pulmonarins A and B, acetylcholinesterase inhibitors from the colonial ascidian Synoicum pulmonaria. J. Nat. Prod. 2014, 77, 364-369.

210. Zhou, X.; Lu, Y.; Lin, X.; Yang, B.; Yang, X.; Liu, Y. Brominated aliphatic hydrocarbons and sterols from the sponge Xestospongia testudinaria with their bioactivities. Chem. Phys. Lipids 2011, 164, 703-706.

211. Elkobi-Peer, S.; Faigenbaum, R.; Carmeli, S. Bromine- and chlorine-containing aeruginosins from Microcystis aeruginosa bloom material collected in Kubbutz Geva, Israel. J. Nat. Prod. 2012, 75, 2144-2151.

212. Elkobi-Peer, S.; Singh, R.K.; Mohapatra, T.M.; Tiwari, S.P., Carmeli, S. Aeruginosins from a Microcystis sp. bloom material collected in Varanasi, India. J. Nat. Prod. 2013, 76, 1187-1190.

213. Vegman, M.; Carmeli, S. Three aeruginosins and a microviridin from a bloom assembly of Microcystic spp. collected from a fishpond near Kibbutz Lehavot HaBashan, Israel. Tetrahedron 2014, 70, 6817-6824.

214. Tian, L.-W.; Feng, Y.; Shimizu, Y.; Pfeifer, T.; Wellington, C.; Hooper, J.N.A.; Quinn, R.J. Apysinellamides A-C, bromotyrosine-derived metabolites from an Australian Aplysinella sp. marine sponge. J. Nat. Prod. 2014, 77, 1210-1214.

215. Tian, L.-W.; Feng, Y.; Shimizu, Y.; Pfeifer, T.A.; Wellington, C.; Hooper, J.N.A.; Quinn, R.J. ApoE secretion modulating bromotyrosine derivative from the Australian marine sponge Callyspongia sp. Bioorg. Med. Chem. Lett. 2014, 24, 3537-3540.

216. Akiyama, T.; Takada, K.; Oikawa, T.; Matsuura, N.; Ise, Y.; Okada, S.; Matsunaga, S. Stimulators of adipogenesis from the marine sponge Xestospongia testudinaria. Tetrahedron 2013, 69, 6560-6564.

217. Li, J.L.; Xiao, B.; Park, M.; Yoo, E.S.; Shin, S.; Hong, J.; Chung, H.Y.; Kim, H.S.; Jung, J.H. PPAR- $\gamma$ agonistic metabolites from the ascidian Herdmania momus. J. Nat. Prod. 2012, 75, 2082-2087.

218. Kim, H.; Kim, K.-J.; Yeon, J.-T.; Kim, S.H.; Won, D.H.; Choi, H.; Nam, S.-J.; Son, Y.-J.; Kang, H. Placotylene A, an inhibitor of the receptor activator of nuclear factor- $\kappa \mathrm{B}$ ligand-induced osteoclast differentiation, from a Korean sponge Placospongia sp. Mar. Drugs 2014, 12, 2054-2065. 
219. Teta, R.; Della Sala, G.; Renga, B.; Mangoni, A.; Fiorucci, S.; Costantino, V. Chalinulasterol, a chlorinated steroid disulfate from the Caribbean sponge Chalinula molitba. Evaluation of its role as PXR receptor modulator. Mar. Drugs 2012, 10, 1383-1390.

220. Nunnery, J.K.; Engene, N.; Byrum, T.; Cao, Z.; Jabba, S.V.; Pereira, A.R.; Matainaho, T.; Murray, T.F.; Gerwick, W.H. Biosynthetically intriguing chlorinated lipophilic metabolites from geographically distant tropical marine cyanobacteria. J. Org. Chem. 2012, 77, 4198-4208.

221. Figueroa, M.; González-Andrade, M.; Sosa-Peinado, A.; Madariaga-Mazón, A.; del Río-Portilla, F.; del Carmen González, M.; Mata, R. Fluorescence, circular dichroism, NMR, and docking studies of the interaction of the alkaloid malbrancheamide with calmodulin. J. Enzyme Inhibit. Med. Chem. 2011, 26, 378-385.

222. Liang, Y.; Li, X.-M.; Cui, C.-M.; Li, C.-S.; Sun, H.; Wang, B.-G. Sesquiterpene and acetogenin derivatives from the marine red alga Laurencia okamurai. Mar. Drugs 2012, 10, 2817-2825.

223. Xu, X.; He, F.; Zhang, X.; Bao, J.; Qi, S. New mycotoxins from marine-derived fungus Aspergillus sp. SCSGAF0093. Food Chem. Toxicol. 2013, 53, 46-51.

224. Halai, R.; Craik, D.J. Conotoxins: Natural product drug leads. Nat. Prod. Rep. 2009, 26, 526-536.

225. Myers, R.A.; Cruz, L.J.; Rivier, J.E.; Olivera, B.M. Conus peptides as chemical probes for receptors and ion channels. Chem. Rev. 1993, 93, 1923-1936.

226. Alewood, P.; Hopping, G.; Armishaw, C. Marine toxins as sources of drug leads. Aust. J. Chem. 2003, 56, 769-774.

227. Nelson, L. Venomous snails: One slip, and you're dead... Nature 2004, 429, 798-799.

228. Shinnar, A.E.; Butler, K.L.; Park, H.J. Cathelicidin family of antimicrobial peptides: Proteolytic processing and protease resistance. Bioorg. Chem. 2003, 31, 425-436.

229. Yu, R.; Kompella, S.N.; Adams, D.J.; Craik, D.J.; Kaas, Q. Determination of the $\alpha$-conotoxin Vc1.1 binding site on the $\alpha 9 \alpha 10$ nicotinic acetylcholine receptor. J. Med. Chem. 2013, 56, 3557-3567.

230. Luo, S.; Zhangsun, D.; Zhu, X.; Wu, Y.; Hu, Y.; Christensen, S.; Harvey, P.J.; Akcan, M.; Craik, D.J.; McIntosh, J.M. Characterization of a novel $\alpha$-conotoxin TxID from Conus textile that potently blocks rat $\alpha 3 \beta 4$ nicotinic acetylcholine receptors. J. Med. Chem. 2013, 56, 9655-9663.

(C) 2015 by the authors; licensee MDPI, Basel, Switzerland. This article is an open access article distributed under the terms and conditions of the Creative Commons Attribution license (http://creativecommons.org/licenses/by/4.0/). 